\title{
Wolof and Wolofisation: Statehood, Colonial Rule, and Identification in Senegal
}

\author{
Unwelcome Identifications: Colonial Conquest, Independence, and \\ the Uneasiness with Ethnic Sentiment in Contemporary Senegal
}

The ethnic friction which characterises classic interpretations of African states is remarkably absent in Senegalese society. Senegal is often presented as a society dominated by Wolof-speakers, particularly in the urban agglomeration of Dakar, which has assimilated large groups of immigrants both socially and linguistically. ${ }^{1}$ This has increasingly led scholars to define Senegal as a predominantly 'Wolof society', whose language is spreading widely (which is sometimes seen as being linked to Murid Islam as well). The Wolof language has migrated from the region of the capital and other urban communities, such as SaintLouis, Tivaouane, Thiès, Diourbel, and Kaolack, into the southern coastal belt towards the Gambian border. This has strongly influenced the interpretation of the history of what is present-day Senegal. Pre-colonial states are therefore often described as 'Wolof states'; their ruling dynasties - if there were any - are defined as 'Wolof'. The Wolof nature of Senegal's political structures is not seriously in question. ${ }^{2}$

As Senegambia is located on the early modern sea routes to India and the slave ports of the so-called Guinea Coast, information on its inhabitants was available to Europeans from an early period. Such information was also provided by Eurafricans, who were most strongly present in Casamance and the Cacheu-Bissau area. ${ }^{3}$ Moreover, European officials managed commercial factories on Senegalese land for centuries, starting as early as the sixteenth century, although their interest was often focused more on the acquisition of slaves and less on the concrete political realities in the hinterland. Nevertheless,

1 Diouf, Mamadou, 'Assimilation coloniale et identités religieuses de la civilité des originaires des Quatre Communes (Sénégal)', Canadian Journal of African Studies 34(3), 2000, 565-87, 570.

2 Diop, Abdoulaye Bara, La société Wolof: tradition et changement: Les systèmes d'inégalité et de domination (Paris: Karthala, 1981), 16-7.

3 Mark, Peter, "The Evolution of "Portuguese" Identity: Luso-Africans on the Upper Guinea Coast from the Sixteenth to the early Nineteenth Century', Journal of African History 40(2), 1999, 173-91. 


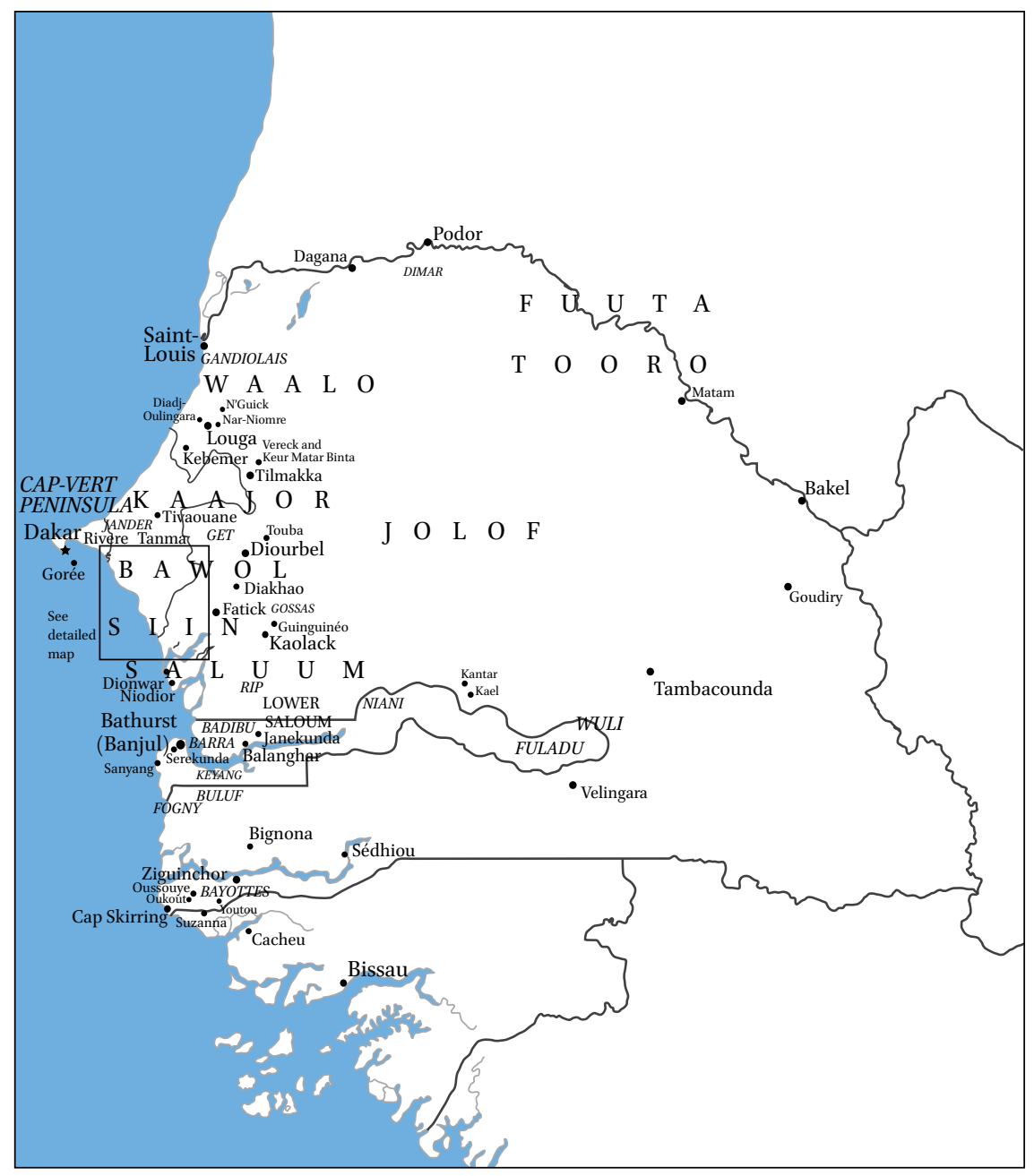

MAP $2 \quad$ Senegambia

commercial activities brought early contact with pre-colonial states such as Kajoor, Bawol, Waalo, Jolof, Siin, Saluum, Fuuta Tooro, Bara in present-day Gambia, and Kaabu in Casamance (Map 2). ${ }^{4}$

From the time of the French conquest in the second half of the nineteenth century, the available source material on local communities becomes more reliable. After the final French victory in the internecine wars in the interior of

4 Becker, Charles, 'Histoire de la Sénégambie du xve au Xvıı siècle: un bilan', Cahiers d'Etudes Africaines 25(98), 1985, 213-42, 230. 


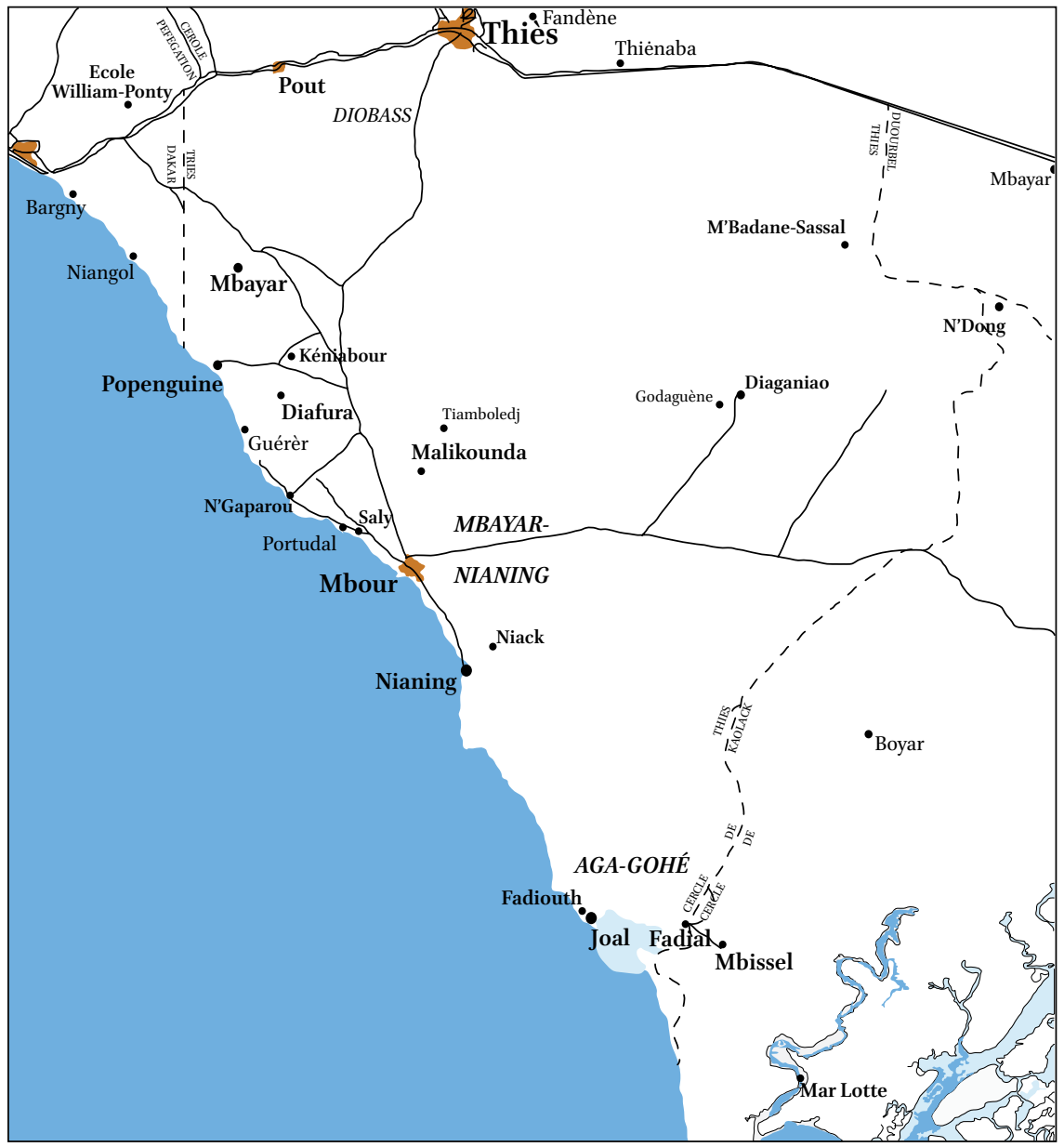

MAP 3

The Petite Côte in Senegal

Senegal, colonial domination allowed for a more comprehensive documentation of the political realities of the territory: after 1850, the French had an early presence on the coast in the settlements of Joal and, for some time, Nianing, and in the nascent peanut production centre of Kaolack in Saluum, and the town of Fatick in Siin (Map 3). ${ }^{5}$ To the south, the British enclave colony of the Gambia,

5 Brooks, George E., 'Peanuts and Colonialism: Consequences of the Commercialization of Peanuts in West Africa, 1830-70', Journal of African History 16(1), 1975, 29-54, 43-4; Klein, Martin A., Islam and Imperialism in Senegal: Sine-Saloum, 1847-1914 (Edinburgh: Edinburgh University Press, 1968), 114-7. 
and the French Casamance completed European control. The remaining rebel movements from the pre-colonial states were in the end unable to cope with the European conquest. The groundwork was thus laid for further investigation into local communities, in an attempt to create a working administration.

Nonetheless, before the 1920 s the French did not create any blueprints for a 'good administration' according to what they regarded as ethnic customs. Priorities were, indeed, very different. Senegal was considered an early model colony, characterised by prosperous peanut cultivation, which absorbed a considerable part of the colonisers' economic concerns. ${ }^{6}$ Senegal was also one of the most 'Europeanised' African colonies in terms of political participation. Following earlier experiments, in 1848 the emerging Second French Republic had conferred voting rights on the Black African and métis (mixed) populations of France's Senegalese colonies. ${ }^{7}$ Immigrants to the early French outposts, the so-called Quatre Communes (Four Communes: Saint-Louis, Rufisque, Gorée Island, and the future capital of Dakar, becoming a settlement area in the 186os), were thus able to enjoy, at least in the long term, the corresponding political privileges, which by 1900 came close to those of European citizens. ${ }^{8}$ These privileged Senegalese were in stark contrast to the large majority of more than go per cent of sujets (subjects) living outside of the territory of the four towns, and were in 1914 the first constituency to send an African representative into a European parliament, the French National Assembly. This distinction would long be at least as essential in political terms as any categorisation on ethnic grounds; it also defined a rural-urban divide. ${ }^{9}$ Later, Senegalese nationalism consequently came to be built on the idea of the urban elites representing the 'civilised centre' of West Africa. ${ }^{10}$ In the post-colonial state of Senegal, the legacy of this tendency towards an elitist and 'Europeanised' political culture

6 Kanya-Forstner, A.S., The Conquest of Western Sudan: A Study in French Military Imperialism (Cambridge: Cambridge University Press, 1969), 28-44; Klein, Islam, 43-4.

7 Diouf, Mamadou, Le Kajoor auXIX ${ }^{e}$ siècle: Pouvoir ceddo et conquête coloniale (Paris: Karthala, 1990), 130-3; Johnson, G. Wesley, The Emergence of Black Politics in Senegal: The Struggle for Power in the Four Communes, 1900-1920 (Stanford: Stanford University Press, 1971), 26-8.

Diouf, 'Assimilation', 582; Hargreaves, John D., 'Assimilation in Eighteenth-Century Senegal', Journal of African History 6(2), 1965, 177-84, 181-2; Johnson, Nancy Kwang, 'Senegalese "into Frenchmen"? The French Technology of Nationalism in Senegal', Nationalism \& Ethnic Politics 10(1), 2004, 135-58.

9 Diouf, Mamadou, 'Lidée municipale: Une idée neuve en Afrique', Politique Africaine 74, 1999, 13-23, 21.

10 Bornstein, Ronald, 'The Organisation of Senegal River States', Journal of Modern African Studies 10(2), 1972, 267-83, 282; Foltz, William J., From French West Africa to the Mali Federation (New Haven - London: Yale University Press, 1965), 137-8. 
was represented by the Parti Socialiste Sénégalais (PSS), successor of the Union Populaire du Sénégal (UPS), and by political leaders Léopold Sédar Senghor and Abdou Diouf.

Ethnic sentiment in Senegal has not in an outright way been denied by the post-colonial political elite, but between the Second World War and the 1970s it was largely downplayed. Ethnic labels appeared in official demographic statistics of the post-colonial Republic of Senegal, but not in elite discourse. ${ }^{11}$ In the rhetoric of political leaders, any existing cultural difference was compensated for by a general feeling of harmony and unity. New attempts in the 1990s to create ethnic associations in Senegalese territory largely failed..$^{12}$ This might explain why scholars have often accepted the idea of a post-colonial Senegal that was harmonious with regard to ethnic oppositions.

In linguistic terms, the post-colonial country has indeed become a largely Wolophone society; this dominance had already become visible in the 1950s. In the present day, up to go per cent of the Senegalese are more or less fluent in Wolof. ${ }^{13}$ Fluency in the colonial language, French, has dwindled to a mere 20 per cent, and knowledge of some French vocabulary has rather become a mark of distinction for urban speakers. ${ }^{14}$ Already in the nineteenth century, even among the African elites of the French outposts, Wolof had enjoyed the role of a lingua franca. ${ }^{15}$ If we accept the results of anthropological research from the

11 Adamolekun, Ladipo, 'Bureaucrats and the Senegalese Political Process', Journal of Modern African Studies 9(4), 1971, 543-59, 551-2; Barker, Jonathan, 'Political Space and the Quality of Participation in Rural Africa: A Case from Senegal', Canadian Journal of African Studies 21(1), 1987, 1-16, 11-2; Fatton, Robert, 'Clientelism and Patronage in Senegal', African Studies Review 29(4), 1986, 61-78, 71-2; Beck, Linda J., 'Senegal's "Patrimonial Democrats": Incremental Reform and the Obstacles to the Consolidation of Democracy', Canadian Journal of African Studies 31(1), 1997, 1-31, 8-9; Boone, Catherine, 'State Power and Economic Crisis in Senegal', Comparative Politics 22(3), 1990, 341-57, 345-7.

12 Coulon, Christian, 'La tradition démocratique au Sénégal: histoires d'un mythe', Studia Africana 10, 1999, 69-83, 81 .

13 McLaughlin, Fiona, 'Senegal: The Emergence of a National Lingua Franca', in Andrew Simpson (ed.), Language \& National Identity in Africa (Oxford etc.: Oxford University Press, 2008), 79-97, 90-1.

14 McLaughlin, 'Senegal', 96-7; McLaughlin, Fiona, 'Dakar Wolof and the configuration of an urban identity', Journal of African Cultural Studies 14(2), 2001, 153-72.

15 Jones, Hilary, 'From Mariage à la Mode to Weddings at Town Hall: Marriage, Colonialism, and Mixed-Race Society in Nineteenth-Century Senegal', International Journal of African Historical Studies 38(1), 2005, 27-48, 35-6; Jones, D.H., 'The Catholic Mission and some aspects of assimilation in Senegal, 1817-1852', Journal of African History 21(2), 1980, 323-40, 328; Sackur, Amanda, 'The Development of Creole Society and Culture in Saint-Louis and Gorée, 1719-1817' (unpublished PhD thesis, School of Oriental and African Studies, 1999), 96-100. 
colonial period, the role of Wolophone merchants and Murid marabouts helped to steadily broaden the language community between 1890 and $1960 .{ }^{16}$ It appears to have pushed other language communities such as the Pulaar (the regional variant of Fulfulde), Sereer, and Jola into the background; from 1945 migration flows to and from the urban centres of Dakar and Saint-Louis had a strong effect on this process. Many of the immigrants became almost exclusively Wolof-speaking. ${ }^{17}$ Social pressure also had a linguistic impact on such processes, in particular in post-colonial public education. For a long period there was little opposition to this trend. ${ }^{18}$

Official figures on ethnic groups over the post-colonial period do not mirror the trends in linguistic affiliation: in 1988, the 'Wolof' percentage of the population is given as 43.7 per cent, compared with 14.8 per cent 'Sereer', 12 per cent 'Pël', 11.2 per cent 'Tukulor', 5.5 per cent 'Diola', and 4.6 per cent 'Mandinka'; other, smaller groups (counted as ethnic) include the 'Sarakole' with 1.1 per cent, the 'Bambara' with 1 per cent, the 'Balante' with 0.7 per cent, and the 'Laobe' with 0.4 per cent. The 'Lebu' are counted as part of the Wolof population in the 1976 and 1988 censuses. ${ }^{19}$

Contrary to studies of Wolof language, Wolof as an identification from a historical perspective is barely present in research on Senegambia. Current historical research focuses much more on 'Wolof' institutions and religion than on the broader identification of the communities. Many scholars seem simply to consider it to be expected that in states where the ruling dynasty was Wolophone, most of the local populations defined themselves as 'Wolof'. In the interpretation of oral historical traditions, the categories of language on the one hand, and cultural group identification on the other hand, are also frequently blurred. ${ }^{20}$

16 Mersadier, Y., Budgets Familiaux Africains: Etude chez 136 familles de salariés dans trois centres urbains du Sénégal (Saint-Louis: Centre IfAN - Sénégal, 1957), 13.

17 Barbary, Olivier, 'Dakar et la Sénégambie: Evolution d'un espace migratoire transnational', in Momar Coumba Diop (ed.), Le Sénégal et ses voisins (Dakar: Sociétés - Espaces Temps, 1994), 142-63, 144-8.

18 Flis-Zonabend, Françoise, Lycéens de Dakar (Paris: François Maspero, 1968), 29-30.

19 Lopes, Carlos, Kaabunké: Espaço, território e poder na Guiné-Bissau, Gâmbia e Casamance pré-coloniais (Lisbon: Comissão Nacional para as Comemorações dos Descobrimentos Portugueses, 1999), 54-72.

20 This relationship remains usually quite vague, as in Diouf's monograph on Kajoor: 'Il existe une unité et une identité de stratification sociale dans la société Wolof malgré la pluralité des formations politiques, dont les fonctions varient selon les désignations ou des charges spécifiques à tel ou tel royaume'; see Diouf, Kajoor, 43; Gamble, David P., The Wolof of Senegambia: together with notes on the Lebu and the Serer (London: International 
With regard to post-colonial issues, it seems difficult to define what 'Wolof' as an identification really means. One of the leading sociologists working on Wolof culture during the post-colonial period, Donal Cruise O'Brien, points out this problem: 'Informants often find it difficult to specify either in general terms who can be identified as a Wolof, or even whether they themselves should be categorised as Wolof ... There are no fixed ethnic boundaries here, no lines of battle drawn up by colonial experience, on the whole no primordialism, rather what may be (for the state) a helpful ambiguity and flux'.21 Historians working on group relations in Senegambia normally do not share this view. In Vincent Monteil's classic studies, the Wolof ethnicity already appears as a homogeneous bloc and as a vital factor within the political entities. ${ }^{22}$ James Searing, in his important studies on the structure of the Senegambian states of Kajoor and Bawol in the nineteenth century, argues for group identity along the same general lines, and the Islamic Muridiyya brotherhood is often presented as the group religion of 'the Wolof'. ${ }^{23}$

But Wolof language also seems to have a role in underscoring the power of dignitaries of one particular community. Praise and song performances were essential cultural elements in both pre-colonial and colonial times to sustain customary rights to land and status for the Wolophone nobility. This social function of the language continues to be important. As regards the performances,

African Institute, 1957), 44-5; Diop, Société Wolof, 138-52; Barry, Boubacar, Le Royaume du Waalo: Le Sénégal avant la Conquête (Paris: François Maspero, 1972), 87-106; Diop, Samba, The Oral History and Literature of the Wolof People of Waalo, Northern Senegal: The Master of the Word (Griot) in the Wolof Tradition (Lewiston/NY - Queenston - Lampeter: Edwin Mellen, 1995), 69-125; Sonko-Godwin, Patience, Ethnic groups Of The Senegambia: a Brief History (Banjul: Sunrise Publishers, 1994 [1988]), 20-7; Fall, Yoro, 'Les Wolof au miroir de leur langue: quelques observations', in Jean-Pierre Chrétien and Gérard Prunier (eds.), Les ethnies ont une histoire (second edition, Paris: Karthala, 2003), 117-23, 117, 121-2; and Diouf, Kajoor, 31-5, 37-40.

21 O'Brien, Donal Cruise, 'The shadow politics of Wolofisation', Journal of Modern African Studies 36(1), 1995, 25-46, 27. Monteil, Vincent, Esquisses Sénégalaises (Wâlo - Kayor - Dyolof - Mourides - Un visionnaire) (Dakar: Publications de l'Institut Fondamental d'Afrique Noire, 1966), 72, 121.

23 Searing, James F., 'God Alone Is King': Islam and Emancipation in Senegal. The Wolof Kingdoms of Kajoor and Bawol, 1859-1914 (Portsmouth/NH: Heinemann, 2002), xxi-xxii; Sy, Cheikh Tidiane, La Confrérie Sénégalaise des Mourides: Un Essai sur l'Islam au Sénégal (Paris: Présence Africaine, 1969), 76-87. See also Glasman, Joël, 'Le Sénégal imaginé: évolution d'une classification ethnique de 1816 aux années 1920', Afrique \& Histoire 2, 2004, 111-39, 112. 
those were carried out by a particular griot or praise-singer caste, the jéwél, who managed social relations between Wolof-speakers. ${ }^{24}$

Obviously, the test case for the importance of an ethnic Wolof identification was contact with 'others'. In coastal Senegambia, Wolof-speakers historically neighboured the groups of the 'Tukulor', the 'Sereer', the 'Jola', the 'Fulbe' (or 'Pël'), the 'Lebu', and the 'Mandinka', in addition to some smaller communities. Their interaction with the Wolophone populations was essential for the latter's self-description.

The Tukulor, a Fulfulde-speaking group, are in Senegambia most prominent in the north-east, but they can also be found in pockets in all of its northern parts, and even in the southern coastal regions and in Casamance. Tukulor cultural identifications are mainly regarded as being linked to the Tijaniyya branch of local Islam, and to the region of Fuuta Tooro, which for the precolonial period is now sometimes depicted as a genuine 'Tukulor state'. In Fuuta Tooro, the Tukulor have kept their distance from Wolophone communities and have rarely intermarried. ${ }^{25}$

As concerns Fuuta Tooro, its populations were characterised by the Jihad experiences of the marabout Nasir al-Din in the late seventeenth century, and the campaigns of Al-Hajj Umar Tall and his successors between $185^{\circ}$ and the 188 os. $^{26}$ From the beginning of the twentieth century, Tukulor populations increasingly started to migrate to the population centre of Dakar. Initially, they showed a clear tendency to marry inside of their own group, which was maintained into the early 196os. Yet in linguistic terms, acculturation to the Wolof language was strong, although it was criticised by a part of the local elite of Fuuta Tooro. ${ }^{27}$

24 Patterson, Amy S., 'A Reappraisal of Democracy in Civil Society: Evidence from Rural Senegal', Journal of Modern African Studies 36(3), 1998, 423-41, 431; Irvine, Judith T., 'When is Genealogy History? Wolof genealogies in comparative perspective', American Ethnologist 5(4), 1978, 651-74; Leymarie, Isabelle, Les griots wolof du Sénégal (Paris: Maison-Neuve \& Larose: 1999), 32-4.

25 Cantrelle, Pierre, 'L'endogamie des populations du Fouta Sénégalais', Population (French Edition ), 15(4), 196o, 665-76, 666-7; Dilley, Roy M., 'Spirits, Islam and Ideology: A Study of a Tukulor Weavers' Song ('Dillere')', Journal of Religion in Africa 17(3), 1987, 245-79, 253.

26 Perinbam, B. Marie, 'Islam in the Banamba Region of the Eastern Beledugu, C. 1800 to C. 1900', International Journal of African Historical Studies 19(4), 1986, 637-57, 641; Robinson, David, 'The Umarian Emigration of the Late Nineteenth Century', International Journal of African Historical Studies 20(2), 1987, 245-70, 252-3.

27 ANS, 11D1/973, Plan de Protection [du Territoire du Sénégal]: Chapitre II: Hypothèses (without number), without date [1957], 11; Diop, Abdoulaye Bara, Société Toucouleur et Migration 
In contrast to the Tukulor, the Sereer populations of Senegambia were, in the nineteenth century, not concentrated in one major political structure. Some, including the Noon, the Safèn, and other Sereer-speaking groups, lived on the margins of the political entities; they were said to reside in autonomous 'clans' in the forest. Sereer-speakers were known for matrilinearity and spirit worship and were thus characterised by overgeneralising French administrators and anthropologists. ${ }^{28}$ Generally, some scholars have drawn a distinction between 'true Sereer' and those being 'assimilated to Wolof culture'. From this perspective, some Sereer groups refused to have any stratified political organisation, and employed the label 'you Wolof' (nga Wolof) as an insult, while some 'Sereer states' were said to be ruled by a 'Wolof elite', such as in the case of Siin. ${ }^{29}$

These opinions seem to find some support in the fact that in the 186os the Buur Saluum (the ruler of the pre-colonial state of Saluum) had a senior official specifically responsible for the administrative and military coordination of the local elite, an official who was called Jaraf Wolof - which seems to point to a state organisation, in which the elite defined itself as 'Wolof'. ${ }^{30}$ For Siin, French documents from the conquest phase indicate that its population was predominantly Sereer. However, the reports of Ernest Noirot, the first French administrator of a short-lived Sine-Saloum district, already cast doubt on this view. Noirot argues that while the majority of Siin's inhabitants appear to be Sereer,

(Enquête sur l'Immigration Toucouleur à Dakar) (Dakar: Publications de l'Institut Français d'Afrique Noire, 1965), 186-7; McLaughlin, Fiona, 'Haalpulaar Identity as a Response to Wolofization', African Languages and Cultures 8(2), 1995, 153-68; Diouf, Kajoor, 20.

28 Barker, Jonathan, 'Stability and Stagnation: The State in Senegal', Canadian Journal of African Studies 11(1), 1977, 23-42, 31.

29 Ba, Abdou Bouri, 'Essai sur l'histoire du Saloum et du Rip', with 'Avant-propos' by Charles Becker and Victor Martin, Bulletin de l'IFAN, Série B 38(4), 1976, 813-6o, 816-26; Sarr, Alioune, 'Histoire du Sine-Saloum (Sénégal)', with 'Introduction, bibliographie et notes', by Charles Becker, Bulletin de l'IFAN, Série B, 46(3-4), 1986-1987, 211-83, 247-51; Gamble, Wolof, 14; Diouf, Kajoor, 21; Gosselin, Gabriel, 'Ordres, castes et Etats en pays Sérèr (Sénégal): Essai d'interprétation d'un système politique en transition', Canadian Journal of African Studies 8(1), 1974, 135-43, 136-7; Klein, Islam, 9-21; Searing, James F., 'Conversion to Islam, Military Recruitment and Generational Conflict in a Sereer-Safèn Village (Bandia), 1920-1938', Journal of African History 44(1), 2003, 73-94, 92.

ANF, Papiers Ernest Noirot, 148/AP/3/1/4, Noirot, administrator of Sine-Saloum, to De la Mothe, Governor of Senegal, Rapport sur la participation des contingents du Saloum à la campagne dirigée contre le Bourba Djiolof. (without number), without date, transcription in Martin, Victor; Charles Becker, and Mohamed Mbodj (eds.), 'Trois documents d'Ernest Noirot sur l'histoire des royaumes du Siin et du Saalum (Sénégal)', Bulletin de l'IFAN, série B 42(1), 1980, 37-85, 56 . 
the ceddo (the members of the military) are to be seen as a rather sizeable, separate group. ${ }^{31}$ The unreliable early statistics tell a similar story: the first census of the new protectorate of Siin indicates a huge majority of Sereer-speakers, and, indeed, no Wolof-speakers at all! ${ }^{32}$ The more detailed censuses for the newly-created district of Thiès, which included many coastal communities formerly belonging to Siin, show that at least in the areas of Joal and Nianing, huge groups of local Wolof-speaking inhabitants had previously been subjects of the Buur Siin. ${ }^{33}$ In Saluum, the great majority of its inhabitants in the interwar period could be described as Wolof-speaking, and the adoption of the language by the rest of the local communities has been presented as an ongoing process. ${ }^{34}$ These contradictions show how complex the issue of identifications on the Petite Côte was, even at this early stage.

31 ANF, Papiers Ernest Noirot, 148/AP/3/3/111, Noirot, Notes sur le pays de Sine: Ses frontières - son sol-sa population - sa constitution - ses cultures - son commerce - dénombrement de la population - état de la population par villages et par catégorie d'individus. (without number), without date [1892], in Martin, Becker, and Mohamed Mbodj (eds.), 'Documents', 64-5.

32 Becker, Charles; Victor Martin, Jean Schmitz, and Monique Chastanet, with contribution by Jean-François Maurel and Saliou Mbaye, Les premiers recensements au Sénégal et l'évolution démographique: Présentation de documents (Dakar, овsтом, 1983), 14-29, reproduces data from Noirot's first census of Siin in 1891, to be found in ANS, GGAOF $22 \mathrm{G}$ 42, and from Lefiliatre's 1904 census, kept in ANS, GGAOF, 1 G 290.

33 Becker, Martin, Schmitz, Chastanet, Maurel, and Mbaye, Recensements, 94, reproduces data from the 'Recensement du Cercle de Thiès de 1904'; CADn, Fonds 'Anciennes Colonies', Fonds Dakar, 293, Gautier, Inspector of Administrative Affairs, Territory of Senegal, Rapport au Chef de Territoire - Exécution de l'ordre de mission $n^{\circ} 3903$ du 15 Juin 1957: Etude des possibilités éventuelles de la réunion des deux cantons de Sanghaïe et Ngayokhème en province de Sanghaïe-Ngayokhème - (application des dispositions de l'article 28 de l'arrêté $n^{\circ} 1978$ APA/2 du 20 Mars 1957) (n $\left.{ }_{17} \mathrm{C} / \mathrm{IAA} / \mathrm{JJG}\right)$, 10 Aug. 1957, 5; CADN, Fonds 'Anciennes Colonies', Fonds Dakar, 192, Michel, Inspector of Administrative Affairs, Rapport: Subdivision de Fatick (Affaires Politiques) ( $\mathrm{n}^{\circ}$ 1), 11 March 1945, 1, 3.

34 Pélissier, Paul, Les paysans du Sénégal: Les civilisations agraires du Cayor à la Casamance (Saint-Yrieix: Fabrègue, 1966), 384-5, 452-3. On the legends of 'Wolof immigration' into Saluum, see CADN, Fonds 'Anciennes Colonies', Fonds Dakar, 293, Gautier, Inspector of Administrative Affairs, Territory of Senegal, Rapport au Chef de Territoire - Exécution de l'ordre de mission $n^{\circ} 3903$ du 15Juin 1957: Etude des possibilités éventuelles de la réunion des trois cantons de Djilor, Sokone et du Niombato en une province dite du Bas-Saloum (application des dispositions de l'article 28 de l'arrêté $n^{\circ}$ 1978/APA.2 du 20 Mars 1957) (n 10C-IAA/ JJG), 3 Aug. 1957, 7. On the 'Wolof majority' in statistics of the subdivision of Foundiougne, see 19. For Wolof group behaviour in seasonal migration, see CADN, Fonds 'Anciennes Colonies', Fonds Dakar, 195, Administrator of Subdivision of Foundiougne, Subdivision de Foundiougne - Rapport Politique, Année: 1956 (without number), without date, 4. On 
The Lebu of the Cap-Vert Peninsula (concentrated in settlements such as Yoff, N'gor, and early Dakar) have been treated as a singular ethnocultural group in anthropological studies throughout the twentieth century, although some researchers see them as speaking a 'dialect' of the Wolof language. ${ }^{35}$ The ethnic distinction was made in professional and religious terms. The Lebu are presented as specialists in fishery, and as followers of their own Islamicsyncretist religious brotherhood, committed to the rules set in the late nineteenth century by Saidi Limamu Laye, a Sufi saint venerated on the Peninsula of Cap Vert. ${ }^{36}$

However, the Layen brotherhood was not exclusive to the Lebu. Wolophone immigrants from the Waalo became a majority of its members, although they eventually became 'assimilated' (lébouisés). The Lebu apparently had a clear notion of insiders and outsiders as regards membership of the group but what it meant to be a 'convert' was complicated, and land rights were connected to 'Lebu-ness' and Lebu political rights. This idea of a community developed from the start of the French protectorate over the Cap-Vert Peninsula in $1857 .^{37}$

As in the case of the Lebu, Sufi Islam, with its strong emphasis on the personal relationship between the marabout and his disciples, offered an alternative approach to group organisation. ${ }^{38}$ Religious leaders attempted to avoid the

Saluum, see Blundo, Giorgio, 'Mbootaay: istituzioni associative tradizionali dei Wolof Saalum-Saalum (Senegal)', Africa (Roma) 45(3), 1990, 384-409.

35 Versluys, Eline, 'Multilingualism and the City: The Construction of Urban Identities in Dakar (Senegal)', City \& Society 2o(2), 2008, 282-300, 286; Duchemin, G.J., 'La République lébou et le peuplement actuel', Etudes sénégalaises 1, 1949, 289-308; Diouf, Mamadou, 'Identité ethnique et vie politique municipale: Les Lébu de Rufisque', in Jean-Pierre Chrétien and Gérard Prunier (eds.), Les ethnies ont une histoire (second edition, Paris: Karthala, 2003), 283-302. Some local historians seem to hold that the Lebu are a mixture ('brassage') of Sereer and Wolof; Mamadou Diouf points to lack of research since 1990, see Diouf, Kajoor, 19.

36 Gallais, Jean, 'Dans la grande banlieue de Dakar: les villages lébous de la presqu'île du Cap-Vert', Cahiers d'Outre-Mer 26, 1954 (avril-juin), 137-54.

37 Laborde, Cécile, La Confrérie Layenne et les Lébou du Sénégal: Islam et culture traditionnelle en Afrique (Bordeaux: Centre d'Etudes d'Afrique Noire, 1995), 47, 62-3; Diop, Momar Coumba, and Mamadou Diouf, 'Enjeux et contraintes politiques de la gestion municipale au Sénégal', Canadian Journal of African Studies 26(1), 1992, 1-23, 7; CADN, Fonds 'Anciennes Colonies', Fonds Dakar, 293, Claude Michel, Administrator of the Banlieue of Dakar and chargé du village indigène of Médina, Note sur l'Organisation Coutumière (Sociale et Politique) de la Collectivité Léboue de Dakar - Texte écourté pour être rendu plus objectif, suivant les indications de la Direction des Affaires Politiques et Administratives.(without number), 1st Nov. 1933, 1-2.

38 Diop, Société Wolof, 247-62. 
divisive effect of tensions between regional and language groups. From $185^{0}$ until the independence of Senegal, the Tijaniyya and the Muridiyya, two strong Sufi brotherhoods, were particularly influential. The Tijaniyya, over the nineteenth century, played a leading role in two Jihads and expanded geographically into the Sokoto Caliphate of Northern Nigeria; parts of present-day Mali; the north-eastern areas occupied by Tukulor populations (and some Fulfuldespeaking nomads) of Senegal; and the city of Kaolack. Tijani power was built on an alliance, negotiated from the last decades of the nineteenth century, between the French authorities and Ibrāhīm Niasse and other Tijaniyya leaders. ${ }^{39}$

The Murids, following the early attempts by their erstwhile leader Cheikh Amadu Bamba, won over the populations of both Bawol and Kajoor. ${ }^{40}$ Their success has often been seen as a challenge to the 'feudal order' within 'Wolof' peasant communities. In creating new villages in the area of Diourbel, the disciples of Amadu Bamba attempted to make belonging to Murid Islam the dominant sense of identification. Nevertheless, while this approach does not pay much attention to ethnic solidarities, in recent studies Murid Islam has often been described as a religion exclusive to the Wolof populations, and as a dividing line between the ethnic categories of 'Wolof' and 'Sereer.'41 For instance, the negative characterisation of the 'Wolof states' as states inhabited by plunderers in much of the research - as exemplified in Cheikh Anta Babou's discussion of the 'devastating effect of political violence in the Wolof society' - mainly reflect a Murid vision of 'pagan' state organisation. ${ }^{42}$ The troops of these pre-colonial states, the ceddo, were largely regarded by the Murids (and the Tijanis) as alcoholic heathens.

Other forms of identification operated as alternatives to possible ethnic solidarity, but also to religious group-building, in Senegal. Under colonial rule the status of slave or former slave, informally maintained long after the emancipation of the late nineteenth century, was one such factor. ${ }^{43}$ Profession

39 Seesemann, Rüdiger, The Divine Flood:Ibrāhìm Niasse and the Roots of a Twentieth-Century Sufi Revival (New York: Oxford University Press, 2011); Kané, Mouhamed Moustapha, 'L'empreinte de l'islam confrérique sur le paysage commercial sénégalais: islam et société en Sénégambie', Islam et sociétés au sud du Sahara 8, 1994, 17-41, 20-2.

40 Behrman, Lucy, 'The Political Significance of the Wolof Adherence to Muslim Brotherhoods in the Nineteenth Century', African Historical Studies 1(1), 1968, 60-78.

41 Charles, Eunice A., 'Shaikh Amadu Ba and Jihad in Jolof', International Journal of African Historical Studies 8(3), 1975, 367-82, 369; Searing, 'God', 20-1; Babou, Cheikh Anta, Fighting the Greater Jihad: Amadou Bamba and the Founding of the Muridiyya of Senegal, 1853-1913 (Athens/oн: Ohio University Press, 2007), 56, see also 80.

42 Babou, Fighting, 55 .

43 Moitt, Bernard, 'Slavery and Emancipation in Senegal's Peanut Basin: The Nineteenth and Twentieth Centuries', International Journal of African Historical Studies 22(1), 1989, 27-50, 30-1. 
could have a similar function, and lead to very divisive identifications, particularly if they were linked to caste traditions. ${ }^{44}$ Some of these caste identifications could be interpreted as ethnic: thus, jewel making was a reputed domain widely associated with 'the Wolof', and river navigation and piloting with the 'Sarakole'.45

Group relations on Senegal's Petite Côte and in the large hinterland of this coast were particularly complex as this region was an area of frequent and significant contact between groups that came to be regarded, in the post-colonial state, as clearly different: specifically, the Sereer and Wolof. Here, Wolofspeaking inhabitants constantly had to deal with neighbours from different linguistic groups. For this reason, the geographical setting provides us with some outstanding material that shows how sense of identification changed over time. These results will be contrasted with conditions in the territory of the former pre-colonial states of Kajoor and Bawol to the north - ruled by Wolophone dynasties - and with those in the British-ruled Gambia to the south.

\section{An Ethnic Pattern in the Mid-Nineteenth Century? Perception and Negotiation of Wolof Group Identification at the Brink of the French Conquest}

With the expansion of French control and the establishment of colonial rule, the encounter between colonial administrators and Wolof-speakers led to a certain perception of the colonial subjects, bolstered by newly obtained information. Started by the Governor of Senegal, Léon Faïdherbe, in the 1840 os and 1850s, the French intensified their military campaigns in the region from the $1870 s$, relying on a complex network of allies. ${ }^{46}$ In this early phase, systematic information-gathering was difficult, as conditions within the French colonies only became more stable after $1900 .{ }^{47}$

44 Diouf, Kajoor, 28; Diop, Société Wolof, 33-45; Tamari, Tal, 'The Development of Caste Systems in West Africa', Journal of African History 32(2), 1991, 221-50, 225.

On jewel makers, see ANS, $11 \mathrm{D} 1 / 5$, District (Cercle) Commissioner of Bas-Sénégal, Notice sur Villes de l'A.O.F.: Satisfaction à 3358/C. du 16 Mai 1940 ( ${ }^{\circ}$ 5), without date; on river navigators ANS, 11D1/1059, Security Service of Senegal, Renseignements Généraux (without number), without date, $1-2$.

46 Barrows, Leland Conley, 'Some paradoxes of pacification: Senegal and France in the 186os', in B.K. Swartz and Raymond E. Dumett (eds.), West African culture dynamics: archaeological and historical perspectives (The Hague - Paris - New York: Mouton, 1980), 515-44, 537-40. ANS, GGAOF, Fonds Ancien, 1Di1, Lafont to Faidherbe, Governor of Senegal (without number), 7 March [1858]; Crowder, Africa, 75-80; Echenberg, Myron, Colonial conscripts: 
Nevertheless, some information coming from the Senegalese populations was indeed processed during this early colonial period, and from the first decades of the twentieth century colonial administrators were instructed to collect historical accounts of the different regions. The stabilisation of colonial political structures on the ground altered the conditions of how local populations defined their ethnic identification. Another factor was the decreasing importance of 'assimilation' as a theoretical objective of the colonisation. Where important local positions had not in the meantime been filled with favourites of French officials, official policy returned to a tendency of restoring the 'traditional dynasties,' favouring in particular veterans who were members of 'noble families'. The seven former states on Senegalese territory ceased to exist, but their dynasties retained some influence because of the colonial policy, which used anthropological work as well to find 'authentic' political structures. 48

In the four-tiered system of the French administration in the West African colonies, the power of 'traditional' chiefs (chefs de canton, who sometimes formally served a 'traditional', honorific chef de region, and who were superior to village chiefs or headmen, the so-called chefs de village) cannot be underestimated. Older research has portrayed the chiefs as mere puppets of the French administrative system. However, in practice the chiefs had a relatively large amount of room for manoeuvre, and could use the colonial structures (the native code or indigénat, and their own role in the recruitment of forced labourers and soldiers) to intimidate local opponents and unwilling peasants. ${ }^{49}$

Within the search for 'authenticity', French administrators felt encouraged to codify 'indigenous customs'. The 'native codices' (coutumiers) classified what the administrators 'identified' as different ethnic communities. 'Native courts' (tribunaux indigènes) were the practical expression of this new policy. The chiefs would accordingly have to prove that they were really competent

the Tirailleurs sénégalais in French West Africa, 1857-1960 (Portsmouth/NH: Heinemann London: James Currey, 1991), 63-4; Michel, Marc, Les Africains et la Grande Guerre: L'appel à l'Afrique (1914-1918) (Paris: Karthala, 2003), 23; Lunn, Joe, Memoirs of the Maelstrom: A Senegalese Oral History of the First World War (Portsmouth/NH: Heinemann, 1999), 121-30.

48 Conklin, Alice, A mission to civilize: the republican idea of empire in France and West Africa, 1895-1930 (Stanford:Stanford University Press, 1997), 162-70; Robinson, David, 'Ethnography and customary law in Senegal', Cahiers d'Etudes Africaines 32(126), 1992, 221-37, 232-4. au Sénégal 1855-1960', Cahiers d'Etudes Africaines 13(50), 1973, 213-38, 234-5. 
and knowledgeable regarding the 'customs' of their populations. ${ }^{50}$ This new demand for authenticity indicated a clear sympathy for 'traditional' and ethnocultural arguments, and also showed local and regional opposition groups a way to challenge the existing rulers: the opposition could accuse these rulers of being 'unauthentic'. ${ }^{51}$

Before the middle of the nineteenth century, the labels of 'Jolof', 'Jaloffa', or 'Gyloffa' appear in many European reports from local representatives and travellers. ${ }^{52}$ It remains rather unclear what is meant by the labels. In many cases, however, the expression did not refer to language; 'visitors' were more interested in political power, and knowledge about the earlier existence of the Jolof Empire as a pre-colonial political entity, destroyed long before the establishment of the first commercial outposts by Europeans, explains most of these views. On the whole, 'Jolof' appears as a political entity, but the name 'Wolof' had variable meanings in the sources.

Documentation on local political entities during the early phase of the French conquest, in the 1840 s and 1850 s, is still scant. From the 1860 os, our material platform broadens: the process of a changing use of ethnic labels in the conquest phase is documented through a multitude of reports describing interactions between Africans and Europeans and highlighting 'the African voice'. The monograph of Abbé David Boilat, an African priest who had spent much time in France, arguably represents the first such document. Boilat explicitly described himself as a 'child of the land', eager to point out the 'correct terms' for the different Senegalese groups. Significantly, he was the first to criticise the tendency of European travellers to regard all Pulaar (or Fulfuldespeakers) as members of a single group; he insisted that the group name 'Pël' only described the semi-nomadic and acephalous cattle-breeder societies, but not other Fulfulde-speakers in the region, such as the Tukulor. ${ }^{53}$

In his account, Boilat holds that distinguishing Senegalese groups by sight was extremely difficult and he discarded any racial-biological distinction. The reference to language is obvious for his description of groups, but Boilat also regarded the Lebu as 'Wolof' who had simply taken a different name. Therefore, local groups would have chosen their labels to suit their needs. With regard to the Sereer-Noon, Boilat distinguished them from the other inhabitants of the

50 Van Hoven, Ed, 'Representing Social Hierarchy: Administrators-Ethnographers in the French Sudan: Delafosse, Monteil, and Labouret', Cahiers d'Etudes Africaines 30(2), 1990, 179-98, 186-9.

$51 \quad$ Zucarelli, 'Chefferie', 221.

52 Hair, 'Continuity', 249-50.

53 Boilat, David, Esquisses sénégalaises (Paris: Librairie Bertrand, 1853), 384. 
region, including from other Sereer-speakers. ${ }^{54}$ Of course, this is in plain contradiction to later descriptions, both from French administrators and anthropologists, and from local interviewees, who all presented the Noon populations as a definite part of the Sereer ethnic group. However, it is likely that Boilat reflected exactly how the members of this latter group wished to be characterised in the middle of the nineteenth century.

Unlike earlier European accounts, the observations of Boilat tackle in part the question of Wolof sense of identification, although, as in the case of Kajoor, he mostly associates Wolofness with the Muslim religion. Citing Fara Kaba, the military leader (farba ju rëey) of the Damel Meysa Tend Joor, Boilat makes 'the Wolof' appear as converts to Islam, in contrast to the Sereer-Noon and SereerSafèn, described by the Kajoor nobility as savage 'tribes'.55 However, the author did not enquire about traditional stories of their origins from the Wolofspeakers. On the contrary, he returned in this respect to Sereer identifications and origins, for which he relied on Tukulor sources describing them as immigrants from the Fuuta Tooro who had finally settled in Bawol. ${ }^{56}$ Boilat's account of Siin is perplexing, as he holds that while the Sereer played a strong numeric role in this state - he frequently mentions the role of Siin's 'Sereer aristocracy' as part of the state hierarchy - he believed these Sereer populations accepted Wolof rule, in particular that of the Muslim king Ramat Diouf. ${ }^{57}$ On Saluum, Boilat's information is far less precise. ${ }^{58}$

In contrast to Boilat's study, Yoro Diaw's account shows how a sentiment of Wolofness could be formulated by the local elites. Diaw was a member of a noble family from Waalo, the pre-colonial state in the northern interior of Senegal, who had undergone an education at the Ecole des Otages in SaintLouis - a school where selected sons of rulers under French domination obtained, while being hostages of the colonial power, a 'French education'. As chief in the Waalo region, his translated accounts convey a perception of common Wolof identifications. ${ }^{59}$ However, Diaw's notebooks illustrate the same

54 Boilat, Esquisses, xv, 43, 59 .

55 Boilat, Esquisses, 174; Klein, Martin A., 'Social and Economic Factors in the Muslim Revolution in Senegambia', Journal of African History 13(3), 1972, 419-41, 427; Diouf, Kajoor, 150-1.

56 Boilat, Esquisses, 179.

57 Boilat, Esquisses, 123, 141, 145-6. It is worth noting that this contradicts the argument of Klein, Islam, 8-9.

58 Boilat, Esquisses, 180.

59 Boulègue, Jean, 'A la naissance de l'histoire écrite sénégalaise: Yoro Dyao et ses modèles (deuxième moitié du XIX ${ }^{\text {ème }}$ siècle, début du Xx ${ }^{\text {ème }}$ siècle)', History in Africa 15, 1988, 395405, 395-6. As is usual for studies on Wolophone communities, Boulègue represents 
initial fixation present in many parts of the colonial administration - the classification of locals according to clear categories - and his account was very much a product of a particular type of 'colonial thinking'.60

A third major account on the situation in the 1860s is the exhaustive report by Emile Pinet-Laprade on the Sereer. This was a colonial document, based largely on information provided to its author by Wolof merchants active in the Cap-Vert peninsula and on the Petite Côte. The informants describe the Sereer with a clear view from outside. ${ }^{61}$ The Sereer appear in this report as first-comers on the Petite Côte, having been led into the region by the Gëlwaar dynasty; the Gëlwaar are said to have come from Kaabu, and they would have been relatives of Jola groups from which they had broken away. According to the Pinet-Laprade account, the children of the founding father of those Sereer conquerors, Massa Wali Dione, had established the states of Siin and Saluum. The 'traditional' explanation is that Sereer groups entered geographic spaces that were uninhabited, and then became isolated, forming sort of ethnic pockets. ${ }^{62}$ However, in Eastern Bawol, the Sereer groups were said to have mixed with the Wolof; they would have adopted a language derived from Wolof, and were distinguished in the period of the author as 'M'Balugiafèn'.63 The account shows complexities for which even the contemporary informants had no answer, and which contradict later ethnic interpretations of group solidarity.

The French, for their part, quickly built up their own know-how in administering larger groups within the Senegambian territories. Intruding more and more into the political scenario of the Cap-Vert peninsula, then of the Petite

Diaw's work from an ethnic perspective, without giving sufficient explanation on this issue: 'Il était le premier Wolof à écrire l'histoire de son peuple' (395).

60 Dyâo, Yoro, 'Légendes et coutumes sénégalaises: les cahiers de Yoro Dyâo', in Revue d'ethnographie et de sociologie, 3-4, 1912, published and annotated by Henri Gaden (Paris: E. Leroux, 1912), 119-37, 191-202; Sall, Tamsir Oumar, 'Yoro Dyao, un aristocrate WaaloWaalo dans le système colonial', Cahiers du CRA 5, 1987, 161-76, passim.

61 Despite Bathily's claim in Bathily, Abdoulaye, 'Aux origines de l'africanisme: Le rôle de l'œuvre ethnohistorique de Faidherbe dans la conquête française du Sénégal', in Cahiers de Jussieu 2: Le Mal de Voir (Paris: Union Générale d'Editions, 1976), 77-107, 97-10o, Léon Faïherbe's own studies are far less fertile on the group identity of Wolophone populations, see Faïdherbe, Léon, Notices sur la Colonie de Sénégal et sur les pays qui sont en relations avec elle (Paris: Arthus Bertrand, 1859), 28-43, and Faïdherbe, Léon, Le Sénégal: La France dans l'Afrique Occidentale (Paris: Hachette, 1889), 153, 354, 364, 431, 482.

62 ANS, G GAOF, 1 G 33, Pinet-Laprade, Governor of Senegal, Notice sur les Serères peuplade répandue sur la partie des côtes occidentales d'Afrique, comprise entre le Cap Vert et la rivière de Saloum (without number), without date, $1-5$.

63 Ans, G GAOF, $1 G_{33}$, Pinet-Laprade, Notice..., 3. 
Côte, French officials increased their knowledge of the different pre-colonial states. ${ }^{64}$ Inquiry into group identifications around the new administrative posts of Rufisque, Dakar, Joal and Kaolack allowed a number of new comments about the social relations of local groups. As far as it concerned the Wolofspeaking rulers of the Senegalese interior, such as in Bawol and Kajoor, the French were obviously concerned with 'states' as a main category. Much of the information usually came from informants at the upper level of the social hierarchy. The process of identifying population groups soon advanced for Kajoor, whose rulers were forced to formally cede a part of their territory in 1858 ; the rest of the state was finally annexed after the defeat of the war leader and exDamel, Lat Joor, in the battle of Dexxelé in 1886. From the 1870s, the French believed they had identified distinct ethnic groups within this state: namely 'Wolof', 'Lebu', 'Sereer', and 'Peul'. Such a conclusion was in plain contradiction with the official version given by informants from the upper echelons of the political hierarchy of Kajoor. ${ }^{65}$ The Damel of Kajoor and his provincial officials described the composition of their state according to three criteria: in terms of the warrior profession of the ceddo, the military elite at the service of the dynasty; the importance of local Muslim clerics providing the religious framework for the inhabitants of the region; and the authority of the Damel himself, and of the ruling families. It is not surprising that the ruling authorities of Kajoor wished to give the French such an image of a homogeneous entity. Even so, ethnocultural conflict between groups was not indicated as a factor in the official account of the mid-nineteenth century. ${ }^{66}$

For Bawol, the second so-called 'Wolof state' on Senegalese territory, which controlled, on the Petite Côte, the growing fishing village of M'Bour, the situation was basically the same in the second half of the nineteenth century. ${ }^{67}$ Members of French military campaigns against this political entity attempted to identify different groups of subjects of the Teeñ, the paramount ruler of the territory, as belonging to particular ethnic groups. ${ }^{68}$ However, this categorisation largely failed: due to confusing social relations within this pre-colonial state, the

64 In 1900 there was one big attempt to bring knowledge on Senegal's 'races' into a single study, based, however, on group stereotypes, see Lasnet, Alexandre-Bernard, 'Les Races du Sénégal. Sénégambie et Casamance', in Exposition Universelle de 19oo, Les Colonies françaises, Une mission au Sénégal, Ethnographie, botanique, zoologie, géologie par мм. Dr. Lasnet, Aug. Chevalier, A. Cligny, P. Rambaud (Paris: Challamel, 1900), 1-190.

65 Diouf, Kajoor, 181-215.

66 ANS, G GAOF, $1 \mathrm{G}_{36}$, Notice sur le Cayor (without number), ca. 1870.

67 Diouf, Kajoor, 153-4.

68 The French also attempted to compile an 'ethnicised' history of the state of Bawol. This pointed to 'Sereer kings' before the takeover of power of the Wolophone geej, but the 
French mainly focused on Bawol's large population of Sereer-speakers, which were, in reality, at the margins of political power and of 'Wolof institutions' ${ }^{69}$

Following the accounts of informants from Saluum, French visitors and diplomats claimed at an early stage that this state consisted of different communities, but that such categories of belonging did not affect its political organisation. French Spiritan missionaries coming to the court of the successive Buur Saluum Bala Adama N'Diaye, Koumba Ndama Mbodj, and Samba Laobe Fall in the course of the 1850 s commented with surprise that the state contained a pluri-lingual society, where the languages of Wolof and Sereer were both very much in use. ${ }^{70}$ In his own correspondence with the French authorities in Gorée, the Buur Saluum, Samba Laobe Fall, expressed the same particular concept of rule over a community defined by criteria of the dynasty. ${ }^{71}$ The central elements of this concept were the loyalty of the different jaraf, the provincial notables, and of the ceddo troops, to the local throne. The Buur Saluum never referred to any ethnocultural characteristics of the populations under his rule. ${ }^{72}$ However, when questioned by British military officer Smyth O'Connor in 1855, the Buur Saluum Koumba Ndama Mbodj gave an image of 'his' subjects that mixed supposed ethnocultural and state loyalty: the ruler held that beyond the borders of his state lived the 'wild tribes' of Bawol; the Sereer and the Lebu; and even the inhabitants of Siin were presented as physically and culturally different. ${ }^{73}$ Those who lived 'in tribes' stood outside the state's society; there was no need even to mention identification as Wolof.

The Buur Saluum's fellow ruler, the Buur Siin, ruler of the neighbouring state closer to the coast, was in conflict with recalcitrant populations who had challenged his authority and later managed to be included in the French zones of influence and protection around Portudal, Nianing, and Kaolack. ${ }^{74}$ These

'tradition' is far from clear. See for that Martin, Victor, and Charles Becker, 'Les Teeñ du Baol: Essai de chronologie', Bulletin de l'IFAN, série B, 38(3), 1974, 449-505, 463.

69 Ans, Ggaof, Fonds Ancien, ${ }_{13} \mathrm{G}$ 312, Aquilichini, Resident of Portudal, to French Commissioner of Gorée ( ${ }^{\circ}$ 74), 6 April 1866.

70 AgCSE, 3 I 1.5a5, Gallais, Quelques notes sur l'origine de Joal, sur les Wolofs et les Cérers, extraites des lettres datées de Joal (without number), without date [ca. 1850], 16.

71 On Saluum genealogy, see Boulègue, Jean, 'Contribution à la chronologie du royaume du Saloum', Bulletin de l'IFAN, série B 28(3-4), 1966, 657-62, passim. ANS, 11D1/1111, Traduction d'une lettre du roi de Salum arrivée à Gorée en Juin 1859 (without number), without date.

73 Smyth O'Connor, Luke, 'Account of a Visit to the King of Bur Sin, 64 Miles to the North of the Gambia', Proceedings of the Royal Geographical Society of London 3(6), 1858-1859, 377-9, 378-9. 
coastal 'Sereer' had, from the point of view of the Buur Siin, Koumba Ndoffène Fa Mak Diouf, decided to leave the good political order of things, which was reflected in the use of the ethnocultural group label for these outsiders. ${ }^{75}$ Nonetheless, Siin counted for the French and local sources as a Sereer entity. ${ }^{76}$ Massa Wali Dione, the abovementioned Sereer hero, was described by informants from Joal-Fadiouth as the founding father of the state of Siin. However, the relationship of this state to other, 'Wolof', entities was not very clear from such accounts. ${ }^{77}$ Early European visitors to Siin agreed that the pre-colonial state and its existing institutions were the point of reference for local populations, not language or customs - and they argued that these political institutions were quite close to comparable ones in Kajoor, Bawol, and Saluum. ${ }^{78}$ The missionaries visiting the court of the Buur Siin Amadiouf Gnilane Faye Diouf in 1851 were eager to remark that he behaved 'exactly like a Wolof leader'. Such instances of behaviour that was 'typical for Wolof aristocrats' perplexed the early missionaries. ${ }^{79}$ It is, however, interesting to note the aftermath of the 1871 assassination of Buur Siin Koumba Ndoffène Fa Mak Diouf during a visit to the town of Joal, now belonging to the French zone on the coast of Senegal. A short struggle for the throne which occurred between Semu Mak Diouf, the son of the late Buur, and Sanu Mone Faye, his half-brother, was mediated through the dynastic rules of the Gëlwaar. Those dynastic rules, Spiritan missionaries explained, were not ethnic customs, but the norms of a pre-colonial state. ${ }^{80}$

After those initial descriptions of self-definition on the basis of the state hierarchies, it is useful to have a closer look at regional cases. In the settlements of the region of the Petite Côte belonging to the state of Siin, in particular in those close to Joal, there was no notion of an 'automatic' Sereer

75 On Koumba Ndoffène Fa Mak Diouf as Buur Siin, see Diouf, Niokhobaye; Charles Becker, and Victor Martin, 'Chronique du Royaume du Sine, suivie de Notes sur les Traditions Orales et les Sources écrites concernant le Royaume du Sine', Bulletin de l'IFAN, série B 34(4), 1972, 702-77, 725-30.

76 Reinwald, Brigitte, Der Reichtum der Frauen. Leben und Arbeit der weiblichen Bevölkerung in Sïn/Senegal unter dem Einfluß der französischen Kolonisation (Münster - Hamburg: LIT, 1995), 61 (on the use of Wolof language in Siin), 67-71.

77 AGCSE, 3 I 1.5a5, Gallais, Complément des notes sur la mission de Joal. Royaume de SineSérères - Wolofs - Joal. (without number), without date [ca. 1850], 1; Reinwald, Reichtum, $154-65$.

78 Compare ANs, G GAOF, 1 G 33, Pinet-Laprade, Notice sur les Serères..., 7-8.

79 AGCSE, 3 I 1.5a5, Gallais, Notes sur la mission de Joal (without number), without date [1851], 37.

8o AGCSE, 3 I 1.11b3, Lamoise to Schwindenhammer, Provincial Superior of the Spiritan Mission (without number), 12 Dec. 1871, 5 . 
identification. This was so even with a majority of the region's inhabitants speaking Sereer languages, although in towns like Guérèr, according to observations made by missionaries, lived a considerable number of Wolof-speaking families. However, the main difference given by the local inhabitants themselves was defined in religious and social terms: a line was drawn between 'Marabout' and 'ceddo' families, which meant allegiance either to Islamic religion or to an institution of the states that was opposed to Islam. The category of 'Sereer' indicated a clear distinction. ${ }^{81}$ However, the Sereer-speakers of the hinterland of Joal, living, during the early phase of French conquest, under the rule of a 'war chief', Akana Dione, described themselves, according to their sub-group, as Noon. These Sereer-Noon, as a community living under constant military pressure, had formulated the strictest rules concerning group endogamy: marriages with 'foreigners', as defined on an ethnocultural base, were strictly forbidden. ${ }^{82}$ For such a seemingly isolated group, its members had, however, an impressive language capacity that contrasted with the insistence of other Sereer-speakers, of N'Dong and of Joal, for example, on not speaking a word of Wolof. When the Spiritan missionary Gallais reached the larger village of N'Dong in 1851, he was surprised how many villagers spoke Wolof. ${ }^{83}$ By the 1880 s, this had become even more the case: young men among the Noon of the Guérèr region were quite fluent in Wolof. The inhabitants of Diafura, close to Guérèr, who approached the Spiritan missionaries as Noon, frequently claimed they did not understand a word of Wolof, and the missionaries at first believed that it was Sereer which they had to learn. Finally, however, nearly all adults spoke good Wolof. As the Spiritans realised after longer contact with villagers on the Petite Côte, there was no fixed boundary between the openly Wolophone part of the inhabitants of Guérèr, and the openly Sereer-speaking individuals in Diafura and its surroundings. ${ }^{84}$

Several rural populations, in their interactions with French missionaries and officers, had obviously understood the political opportunities generated by insistence on their difference from the Wolophone populations of the region. With the Spiritan missionaries, those villagers were relatively successful:

81 AGCSE, 3 I 1.11b3, Strub to Kobès, Coadjuteur (in function of bishop) of the Two Guineas (without number), 8 May 1885, 2.

82 ANS, 10D5/12, Monographie des Sérères Nones: Les Nones (without number), without date, 4. The idea of the Sereer being an acephalous society with ad hoc war chiefs is, however, difficult to sustain from the archival sources, which are hardly explicit.

83 AGCSE, 3 I 1.5a5, Gallais, Notes sur la mission de Joal (without number), without date [1851], 6 .

84 AGCSE, 3 I 1.11b3, Strub to Kobès (without number), 13 May 1885, 3. 
the missionaries believed for a time that the Noon, as an important 'independent tribe', had the right to rule over the whole geographic zone to the fringes of the French posts of Pout and Thiès and enjoyed a fair claim to protection as an independent unit against Bawol and Siin. Those claims were entirely fictitious in terms of political history, as the Sereer Noon were only a dispersed group at the margins of those political entities. French military personnel coming into the region from the 1880 s were from the outset far more sceptical towards Akana Dione's claims. ${ }^{85}$

Further northwards on the coast, in Popenguine, there was another type of community organisation to be found, which came rather closer to ideas of ethnic distinction. In Popenguine, communities were classified into the Sereer town and the White (tuubab) settlement, meaning, effectively, French and Wolof town. This distinction between both settlements was already part of the local vision in the $1880{ }^{8} .{ }^{86}$ In this case, language appeared to define the notions of ethnic identity, but the distinction was made elsewhere: under pre-colonial conditions, prominent Wolophone individuals and French merchants were regarded as loyal subjects of the ruler, while the inhabitants of the 'Sereer town' were more resistant towards the demands of the rulers and notables of Siin (and, ultimately, of Bawol, as Popenguine occasionally changed hands between both states during periods of warfare). Thus in the end, the question of political affiliation played a more important role than ethnic sentiment.

From the 1850 s to the 1880 s, such demands were still part of a normal regional practice. In earlier decades, the Buur's political decrees for the collection of tribute had usually been a prelude to plunder. The definition of ethnic groups did not play a role in the payment of those 'taxes': there was no distinction between Sereer-speakers and Wolof-speakers as concerning treatment by the authorities of Siin. ${ }^{87}$ Tribute relations and eventual reprisals were estimated on the basis of allegiance to agents of the state. In the 1860s, different groups attempted to escape the control of the Buur and to obtain French protection, such as in the coastal villages of Dionwar and Niodior, whose inhabitants were imprisoned and severely beaten under the orders of local ruler N'Diarnou, a vassal of the Buur Siin. The state (or the opposition against the state) was the point of reference of group loyalty, not the ethnic group.

\footnotetext{
85 AGCSE, 3 I 1.11b3, Strub to Kobès (without number), 25 May 1885, 4-5.

86 AG CSE, 3 I 1.11b3, Strub to Kobès (without number), 27 Oct. 1885, 2; AGCSE, 3 I 1.11b3, Strub to Kobès (without number), 4 Jan. 1886, 1.

87 ANS, GGaOf, Fonds Ancien, 13 G 314, Bandis to Cools, Commissioner of Gorée (without number), 29 Jan. 1868.
} 
Loyalties on the Petite Côte, and in particular in the interior eastward from the coastal belt, were rendered still more complicated by the religious conflicts of the 1860 s. Several of the village rulers in question, who had come to power since 1850 , owed their nomination to Islamic zeal and to their installation by Ma Bâ, an anti-French religious leader operating in the Siin-Saluum area and preaching Islamic Jihad in middle and southern coastal Senegal. ${ }^{88}$ In the whole of his personal correspondence with the French side, Ma Bâ insisted that 'Muslim villages' in the area of the Siin and Saluum Rivers were threatened by 'pagan communities', and his own followers never had recourse to ethnic terms. Ma Bâ's alliance with ex-Damel Lat Joor was also built on Islamic credentials. ${ }^{89}$ Religion thus overshadowed other solidarities within the Wolophone communities of this particular region. ${ }^{90}$

Nonetheless, it was above all the nature of state organisation in Senegambia that caused the absence of ethnic criteria. The ethnic variant of group categorisation was mostly limited to groups at the periphery, and at the margins of state control. The Wolof-speakers, wherever they were a leading group in precolonial state structures, never referred to their own ethnocultural sentiment in their conversations with the French conquerors. On the contrary, the elders and leaders of those communities that were victims of plunder and violent tribute campaigns tried the counter-strategies they had at hand: they claimed their distinctness from the ruling elite of the pre-colonial states in question. Especially the Sereer, but also the Tukulor groups of the Petite Côte, and the Lebu, all resorted to these means to prepare armed resistance.

The Petite Côte and its hinterland provide, in the decades after 1850, a number of detailed examples of these different processes of group resistance. During the era of slow French conquest of the Senegalese interior, many local

88 ANS, G GAOF, Fonds Ancien, $13 \mathrm{G}$ 314, De Beaurepaire to Cools ( $\left.{ }^{\circ}{ }_{35} 6\right), 8$ Feb. 1868.

89 ANS, GGaOF, Fonds Ancien, $13 \mathrm{G}$ 318, Lettre [de Maba] parvenue le 10 Juin 1864 (without number), without date; ANS, G GAOF, Fonds Ancien, 13 G 318, Ma Bâ to Faïdherbe (without number), without date (May 1864); ANs, GGAOF, Fonds Ancien, 13G 318, Ma Bâ to PinetLaprade, Commissioner of Gorée, and Faïdherbe (without number), without date; ANs, GGAOF, Fonds Ancien, 13 G 318, Ma Bâ to Pinet-Laprade (without number), without date; Klein, Islam, 79-93; Diouf, Kajoor, 231; Getz, Trevor R., Slavery and Reform in West Africa: Toward Emancipation in Nineteenth-Century Senegal and the Gold Coast (Athens/он: Ohio University Press - Oxford: James Currey, 2004), 146-7.

9o The movement of Ma Bâ has later been described as a 'Tukulor movement' in the style of Al-Hajj Umar's group of followers, but the overwhelming part of his militants were Wolofspeakers. See CADN, Fonds 'Anciennes Colonies', Fonds Dakar, 192, Michel, Administrative Inspector of the Colony of Senegal, Rapport: Subdivision de Nioro du Rip $\left(\mathrm{n}^{\circ} 3\right), 20$ April $1945,5^{-6 .}$ 
leaders saw their chance to profit from the decrease of state control, and attempted to build up a reputation of their own. Some of those jaraf even established their own autonomous strongholds in the vacuum of power that was the consequence of the loss of control by the buur. They still referred to the same system of state organisation: thus, even if the rebellious officials led a large number of non-Wolophone followers, they usually did not try to build their revolt on ethnocultural sentiment, but on networks and resource redistribution. As one example, the chief of Fadial, Moussa Diahame, who had been deposed by the Buur Siin and fled before the advent of the latter's ceddo in June 1868, was especially prestigious. He built up most of his prestige as a result of active patronage, through the distribution of his cows and sheep. ${ }^{91}$

During the chaotic political situation of the years between $185^{\circ}$ and 1890 , however, some regional group solidarities crossed the boundaries of the states. Wolof-speaking traders from Joal on the Petite Côte and from Gorée strongly relied on links to other regions for their commerce. In those networks, they cooperated with members of their families and other Wolophone partners, but not in the sense of an ethnic solidarity.92 The Wolof-speaking chiefs of the areas near Nianing and Kaolack saw no problem in collaborating with Fulbe raiders in order to enhance their local power base. New patronage networks emerged in which ethnicity continued to play no role. One of these local warlords was Songho, operating first as an ally of Makodu, the erstwhile Damel of Kajoor, and attempting at the same time to befriend the French..$^{93}$ Ten years later, after the French had put the region of M'Biguen under their own protection, their relationships towards local rule and individual leaders were complex: Songho had remained a regional leader in the hinterland of the Petite Côte in the 186 os and the 1870 s, and while he officially cooperated with the French-installed chef de canton, he claimed, at the same time, to be under the authority of Lat Joor, now pretender for the damelship of Kajoor. While the erosion of Kajoor, Bawol, and Siin thus led to the establishment of leaders working individually, parties in the resulting conflicts nonetheless still operated with clear reference to the pre-colonial states.

91 ANS, G GAOF, Fonds Ancien, 13G 314, Noël to Commissioner of Gorée ( ${ }^{\circ}$ 394), 3 June 1868.

92 ANS, 11D1/1111, Kobès, Acting Bishop of Modon, Divers points qu'il serait important de régler dans les négociations avec le roi de Sin en faveur de la Mission de Joal (without number), 10 Dec. 1855 . pour le Chef de Bataillon du Génie Pinet Laprade ( $\left.\mathrm{n}^{\circ} 71\right)$, 10 Nov. 1860, 3-4. 
The French attempted to inspire the creation of a rival network, including the major Wolof-speaking chiefs and some Sereer-speaking headmen in the coastal area. To better control the region of the Petite Côte from 189o, French officials wished to counter the claims of Songho, but they also planned eventually to eliminate those chiefs in the region who were still formally loyal to the Buur Siin or to the Teeñ. ${ }^{94}$ However, many local leaders established their own network of clients and managed to ignore for years the overlordship of the French-installed Alcati of Nianing, Moktar Diop, and of Lamane Gamou, the French stalwart in the region of M'Biguen. The 'Pël' - the armed Fulbe communities of cattle-breeders who were readily mobilised for attacks - played a central role in this local network; moreover, they were frequently engaged on both sides. ${ }^{95}$

During these events, the Buur Siin also felt - after the conquest of Fatick by the French in 1859 and new French territorial claims - that he had to explain his own point of view. In his argumentation towards the French opponents, the Buur Siin claimed, first, that the villagers in the area in question would manipulate information to artificially create tensions between him and the French governor. His second and main argument remained dynastic. The Buur Siin claimed that he and his fellow ruler and 'brother', the Buur Saluum, were the representatives of the region's 'traditional' ruling families, holding a centuries-old right to govern. This was also explicitly stressed in the context of other dynastic claims, such as in the cases of Lat Menguey, former Buur Saluum, or of Koumba Ndoffène Fa Mak Diouf, the Buur Siin, who wished to defend his rights of succession in Bawol. ${ }^{96}$ In 1868, the Buur Siin sent more envoys to intimidate and discipline the inhabitants of Fadial and of other villages that had attempted to break away from the state. At the same time, local chiefs and translators were dispatched on behalf of the French to insist upon the treaties of local communities with the French residents in Nianing and

94 ANS, GGAOF, Fonds Ancien, 13G 314, Noël, Administrator of Post of Joal, to Commissioner of Gorée ( $\left.{ }^{\circ}{ }^{\circ} 8\right), 17$ March 1868; ANs, G GAOF, Fonds Ancien, ${ }_{13} G_{314}$, Noël to Commissioner of Gorée ( $\left.\mathrm{n}^{\circ} 399\right), 16$ June 1868.

95 ANS, Ggaof, Fonds Ancien, 13 G 314, Reygane, District Commissioner of Bidjine, to Commissioner of Gorée ( $\left.{ }^{\circ} 2\right)$, 2 Jan. 1870.

96 ANS, GGAOF, Fonds Ancien, ${ }_{13}$ G 318, Lat Menguey, son of Bala, former Buur Saluum, to Majojo, Damel of Kajoor, and Faïdherbe (without number), without date (arrived 20 June 1864); ANs, G GAOF, Fonds Ancien, 13 G 318, Koumba Ndoffène Fa Mak Diouf, Buur Sïn, to Faïdherbe, Governor of Senegal (without number), without date (arrived 12 Oct. 1864); ANS, GGAOF, Fonds Ancien, 13 G 318, Bakar Thilas to Faïdherbe (without number), without date (arrived 1 March 1864). 
Joal. ${ }^{97}$ For our discussion, it is most interesting that in those negotiations, the question of ethnic belonging did not appear. Conflict on the Petite Côte remained fixed between the pre-colonial state and local communities, without any need for the conflicting parties to refer to group identifications in an ethnic sense. ${ }^{98}$

Only when the political situation became particularly menacing from the point of view of the ruling dynasties did the rulers of Siin or Saluum occasionally formulate the danger of a 'foreign' threat represented through a 'stranger' ethnic group. This appeared to help them to close ranks. Such was the case during the conflict between the French and Makodu, who had then become a contender for the throne of Siin. Makodu insisted in his speeches and letters that the inhabitants of Siin ought to expel all the 'foreigners', particularly the 'Tukulor' - thus mobilising against the auxiliary troops of the French army. ${ }^{99}$ However, in the nineteenth-century context, such claims were rare. Makodu was already in a desperate situation - and the ethnic card appeared only as a last resort in situations in which religious, communal or state solidarity no longer produced the desired effects.

At least, this was the case for the rulers and authorities of the pre-colonial states. By contrast, for smaller groups, such as the Lebu, Sereer, or Tukulor living in Western Senegal, the situation was quite different. They were under far more pressure, and on the Petite Côte their communities could normally not rely on any protective state structure. Their former modus vivendi with Wolophone rulers of the pre-colonial states had been eroded through the constant warfare in the region from the first half of the nineteenth century. Groups

97 ANS, GGAOF, Fonds Ancien, 13 G 314, Noël to Koumba Ndoffène Fa Mak Diouf (without number), 16 June 1867; ANS, GGAOF, Fonds Ancien, ${ }_{13} \mathrm{G} 314$, Noël to Administrator of $2^{\mathbf{e}}$ Arrondissement in the Colony of Senegal, Supplément à la lettre $N^{\circ} 399$ (without number), without date; ANS, G GAOF, Fonds Ancien, ${ }_{13}$ G 314, Noël to Commissioner of Gorée (number illegible), 20 June 1868 .

98 ANS, GGaOf, Fonds Ancien, 13 G 318, Lettre [du Roi de Sine] parvenue le 6 Juin 1859 [Traduction] (without number), without date; ANS, GGAOF, Fonds Ancien, $13 \mathrm{G}$ 318, Lettre [du Roi de Sine] parvenue le 6Juin 1859 [Traduction] (without number), without date; ANs, GGAOF, Fonds Ancien, $13 \mathrm{G}$ 318, Buur Siin to Commissioner of Gorée (without number), September 1859; ANS, G GAOF, Fonds Ancien, 13G 318, Farba Diaraf Waly to Mayor of Gorée ('Toubou Saint Jean') (without number), without date (arrived 8 July 1860); ANs, GGAOF, Fonds Ancien, ${ }_{13} \mathrm{G}$ 318, Buur Siin to Faïdherbe (without number), without date (arrived 1861); ANS, GGaOf, Fonds Ancien, 13 G 318, Buur Siin to Pinet-Laprade and Faïdherbe (without number), July 1860.

99 ANS, GGaOF, Fonds Ancien, ${ }_{13} \mathrm{G}$ 318, Bakar Thilas, Buur Siin, to Faïdherbe (without number), 13 June 1863 . 
at the margins of political units now still more frequently became the victims of plunder. In situations of conflict, such communities occasionally relied on ethnocultural mobilisation strategies as a tool for obtaining group cohesion.

In some attempts at classification already carried out by the French in the 1820s, all West Africans under French rule appear as 'lébous'. ${ }^{100}$ This might partly be based on a misinterpretation of African information, but it is also probable that 'Lebu' in the first half of the nineteenth century was more flexible as a group label. In Jander, a peripheral province of Kajoor in 1860, a French agent collected yet another explanation of 'Lebu' group identity. According to his report, the criterion of difference was mainly based on religious identification: those called 'Leybou' were simply the inhabitants of villages untouched by Islam, where alcohol could be consumed. ${ }^{101}$ To the Damel of Kajoor and to the Teeñ of Bawol, the 'Lebu' outside of their area of direct control were therefore regarded as legitimate targets of military campaigns. ${ }^{102}$ This called for creating stronger group cohesion between the victims of plunder campaigns, under this label, to counter the existing threats.

In the regions between Bargny and the mouth of the Tanma River, traditions held the local populations to be a 'mixture' of Lebu and Sereer. ${ }^{103}$ By contrast, close to M'Biguen, in Jander, a province of Kajoor slowly detaching itself from the Damel's control and coming under French influence, the locals described the inhabitants of large zones of the area as 'Ouolofs lébous'! This contradicted the logics of ethnic identification. The populations in the region spoke a dialect of Wolof (as indeed did several groups of Sereer in Jander, in spite of having a different group label). The great majority were non-Muslims, devoted to more local cults. ${ }^{104}$ Their precarious position regarding the Wolophone rulers of the neighbouring pre-colonial states made it attractive to rely on this common identification in cases of crisis. Only after the French conquest did the Lebu communities no longer need the group distinction, and it could then entirely be replaced by religious affiliation to the teachings of the Layen.

100 ANS, G GAOF, 1 G 9, Villoz, Rapport fait à la commission de Statistique coloniale relativement à l'examen des divers mémoires envoyés au Ministère de la Marine et des colonies en réponse aux demandes de renseignemens statistiques faites par le ministère concernant le Sénégal et les établissemens qui en dépendent (without number), dated 1825.

101 ANS, GGAOF, Fonds Ancien, 1D17, Vincens, Chef de Génie, Rapport sur la reconnaissance militaire exécutée dans le Diander du 24 au 278 bre $1860\left(\mathrm{n}^{\circ} 1\right), 15$ Sep. 1860, 4.

102 ANS, GGAOF, 1 G 33, Commissioner of Gorée, Note sur l'Organisation du Diander (without number), without date.

103 ANS, G GAOF, 1 G 33, Pinet-Laprade, Notice sur les Serères..., 3-4.

104 ANs, GgAof, 1 G 33, Pascal, Notes sur le Diander recueillies par Mr. Pascal, Lieutenant D'Infanterie, Commandant le Poste de M'Biguen (without number), without date. 
Such processes of self-definition of local groups towards Wolophone rulers are still more complex for the Fulfulde-speakers of Senegal who lived outside of the Fuuta Tooro region. In the coastal regions, the 'Tukulor' appeared as a clearly distinctive group, still much more than the Lebu or the Sereer. They were perceived as such not only by the French, but also by the other local groups, including notably the Wolof-speakers. For the second half of the nineteenth century, this distinction had obvious political reasons. Samba Niang, head of a trading firm, reacted to a number of attacks on Fulfulde-speaking merchants in the area of Portudal with a new emphasis on Tukulor solidarity. Niang managed to mobilise the members of this group to form a strong defensive association; a common group identification justified joint action. ${ }^{105}$

These Tukulor merchants and soldiers were migrants from three different regions in the north-east, including Fuuta Tooro. Wolophone informers told Martin, the French Resident of Portudal, that the 'Tukulor traders' formed a sort of dangerous, 'tribal', 'secret society'. Indeed, the Tukulor of Bawol, of Siin and of Saluum, feeling exploited by the ruling dynasties and by the administration of the pre-colonial states, all stressed, in the second half of the nineteenth century, their particular group identification. Apart from adherence to the Tijaniyya, their emphasis lay on terms of geographic origin, and the Fulfuldespeaking merchants described themselves as 'Muslims from Fuuta Tooro'. 'Being Tukulor' was thus an important trope, repeated over and over again even in written correspondence with the French. ${ }^{106}$

In Dakar, the identification as 'Tukulor' was regarded by the Wolophone residents as a problematic other, expressed through strong and negative stereotypes. 'Here, "Tukulor" is above all a synonym for plunderer, thief and liar', commented the French official Martin. Among Sereer-speakers, the opinion on the 'Tukulor' was similar. In fact, the above-mentioned Samba Niang, selfstyled 'Tukulor leader', was able to mobilise some hundred warriors of the Fulfulde-speaking community on the coast to attack and to plunder the Sereer village of Fallokk, in a vengeance campaign for Sereer banditry. They also attacked Joal. During such episodes, the feeling of solidarity between the Muslim 'Tukulor' was remarkably high: some of the warrior-traders involved in the campaign even interrupted their lucrative commercial business in other parts of the coast and came down with their arms and dependents into the Joal region to defend their 'brethren' against the Sereer. Nevertheless, ultimately this group was not large enough to match the French counter-activities: Niang

105 ANS, G GAOF, $1 \mathrm{G} \mathrm{28}$, Martin to Commissioner of Gorée (without number), 11 June 1863.

106 ANS, 11D1/1111, Traduction d'une lettre reçue des Toucouleurs de Salum. en Juin 1859 (without number), without date. 
and his officers were defeated and rather easily captured by French troops and their Wolophone auxiliaries. ${ }^{107}$ The events in themselves were, however, quite significant for an ethnicised style of group mobilisation in Senegambia's coastal areas during a certain period of insecurity. After the failure of Samba Niang's campaign and the stabilisation of political conditions on the Petite Côte through rapid French expansion, the 'Tukulor identity' of individuals in that region and in the Siin-Saluum became dormant for much of the early twentieth century. It only reappeared in the period immediately before independence, although in an unexpected way.

In the 1860 os and 1870 os, the Sereer on the Petite Côte had their own visible moments of ethnic mobilisation, albeit through a very complex process. Many Sereer-speaking communities were obviously content to be spared, by the French intervention in this part of the future colony of Senegal, from the constant tribute-raising and raiding by ceddo troops sent by the rulers of the inland states. French protection, although combined with new tax obligations, had nonetheless led to an improvement in their overall economic situation. For those reasons, the inhabitants of many Sereer-speaking village communities in the region were ready to collaborate with the Wolof-speaking Alcati of Nianing. In the Tanma, the former Sereer-speaking region of Kajoor at the northern margin of the area analysed here, only a remarkably small number of Sereer villages refused from the outset to pay their taxes to this 'Wolof' middleman.108

Other, smaller groups in the coastal area attempted to obtain more political rights through the French conquest of the region of Kaolack. In Nianing, the Sarakole and Bambara inhabitants managed first to be treated differently with regard to the payment of taxes. Members of both groups argued for their distinctness as different ethnic groups. In this newly created canton - a colonial administrative unit - the strategy was increasingly successful. After a short period, the French residents started to regard them as communities that had nothing to do with the 'majority populations' (Sereer and Wolof) of their immediate surroundings. The creation of a local tradition emphasising their distinct experiences had the central role in this process, which eclipsed the earlier reality of the Nianing region as an area of very different communities belonging to one entity. ${ }^{109}$

107 ANS, GGAOF, 1G 28, Martin to Pinet-Laprade, Commissioner of Gorée (without number), 23 June 1863 .

108 ANS, GGAOF, Fonds Ancien, 13 G 318, Pinet-Laprade to Faïdherbe (first page is missing, missing page numbers), missing date, passim.

109 ANS, GGAOF, Fonds Ancien, 13G 312, Aquilichini, French Resident in Portudal, to French Commissioner of Gorée ( ${ }^{\circ}$ 99), 31 Jan. 1867. 
Many Sereer communities were, between $185^{\circ}$ and 1900, characterised by internal land conflicts having to do with early peanut production, and which were detached from any clear Sereer-Wolof dichotomy. This became obvious in a series of conflicts of the 1870 os in the zone around the French fortress of Portudal. After the burial of the paramount chief Dione in early March 1878, several hundred 'Sereer' warriors assembled in Niangol. ${ }^{110}$ The French had been warned by Wolophone informants about the 'savagery' of 'the Sereer'. However, the reality was far more complex: Dione had ruled a group of both Wolof-speakers and Sereer-speakers, and he was a former subject of the Buur Siin, and a colleague of the Alcati of Nianing supported by the French into the 188os. The 'Sereer' who then attacked the French garrison were a specific group, the inhabitants of two villages, namely Malikunda and Ginko. These warriors continued their traditional feud with Sango, the village chief of Niangol, who was himself a Sereer-speaker. ${ }^{111}$ During these particular troubles, the lines of conflict were thus between smaller communities, and, as such, entirely misunderstood by the French authorities. The latter planned a retaliation campaign against 'the Sereer' as a whole, but such measures did not correspond to the realities of group affiliation in the region. ${ }^{12}$

The case of Dibur, installed as a tax official by the French in the region of Saly in the 1870 , is also instructive. Dibur encountered serious difficulties during his task, and was even attacked by Sereer-speaking warriors from Malikunda and Cacune. ${ }^{113}$ Subsequently, the populations of N'Gankul and of Saly armed themselves, and defended, as they regarded it, their territory against the marauders from the neighbouring villages. The Wolof-speaking canton chief, N'Dende Diagne, announced that he felt powerless against the raiders. The French resident promised a 'pacification campaign' in the region, but French troops were now occupied in the east of Senegal, and the campaign did not materialise. Consequently, the coastal populations mobilised themselves. In the vacuum of power and under instability, the Wolophone settlers of Saly took up arms against a 'Sereer enemy'. Although this enemy was no homogeneous Sereer army, but rather a group of pillagers coming from various villages

110 ANS, GGAOF, Fonds Ancien, 13 G 313, Administrator of $2^{\mathrm{e}}$ Arrondissement in Dakar to Brière de l'Isle, Governor of Senegal, Attaque du poste par les Sérères $\left(\mathrm{n}^{\circ} 53\right), 9$ March 1878 , 1; ANS, GGAOF, Fonds Ancien, 13G 313, Administrator of Post of Portudal to Brière de l'Isle $\left(\mathrm{n}^{\circ} 564\right), 8$ March $1878,1-2$.

111 ANS, GGAOF, Fonds Ancien, ${ }_{13} \mathrm{G}$ 313, Sabatier, Rapport au sujet des faits qui se sont passés au poste de Portudal le 5 et le 6 mars 1878 (without number), 10 March 1878, 1-3.

112 ANS, GGAOF, Fonds Ancien, ${ }_{13} \mathrm{G} 313$, Administrator of $2^{\mathrm{e}}$ Arrondissement in Dakar to Brière de l'Isle $\left(\mathrm{n}^{\circ}\right.$ 54), 15 Feb. 1879, 2.

113 ANS, GGAOF, Fonds Ancien, $13 \mathrm{G}$ 313, George to Brière de l'Isle ( $\mathrm{n}^{\circ}$ 19), 8 Feb. 1879, 1-2. 
in the interior of the coastal belt, formulating an ethnic antagonism was here for once a helpful strategy. ${ }^{114}$

It is essential to point out that mobilisation of that type remained a last resort in nineteenth-century coastal Senegambia, employed when the other, established structures, which had been useful in containing local violence between communities, were ineffective. At the end of the 1870s, the precolonial states had broken down, and the colonial state did still not work. Under those circumstances, ethnic sentiment was sometimes operational as an alternative.

\section{The Difficult Balance: Wolof-Speaking Elites and Local Group Opposition, 1900-1945}

A part of the colonial conquest involved the creation of structures of authority amongst 'acephalous people'. A large percentage of the local populations on the Petite Côte had before been used to overlords from the states of Siin, Saluum, and Bawol. Some others, however, had been members of isolated groupings. They were now the target (and the victims) of the installation of new chiefs, who were, in this early phase, mostly the old allies of the French from the military campaigns. ${ }^{115}$ This development put a strain on the relations between rulers and locals, as many of these new chiefs came from other parts of Senegambia, that is, from the north and north-east. ${ }^{116}$ This occasionally allowed for forms of ethnic mobilisation, but it did not translate into a simple antagonism of (newly installed) Wolof rulers and Sereer subjects.

The Wolophone ruler Madiouf Diouf, installed as chief of Fatick in 1888, is an instructive case. He had serious problems in imposing his rule in the area, but the Sereer-speakers of Fatick were not his principal enemies. His Sereer subjects had no clear opinion about the changes under colonial rule in comparison to the rule of the Buur Siin. Diouf's main adversaries were Wolophone merchants from the coastal towns who belonged to a strong network. ${ }^{117}$

114 ANS, GGaOF, Fonds Ancien, 13 G 313, Lenoir, Director of Political Bureau of Senegal, to Administrator of $2^{\mathrm{e}}$ Arrondissement (without number), 14 Feb. 1878, 1-2.

115 Bruschi, Francesca, 'Politique Indigène et Administration au Sénégal (1890-1920)', Politico 70(3), 2005, 501-22.

116 Klein refers to the example of the chiefs Mandiaye Bâ and N'Deri Kani, who were frowned upon by Sereer and Mandinka villagers because of being 'Wolof', see Klein, Islam, 154-5.

117 ANS, GGaOF, Fonds Ancien, ${ }_{3} \mathrm{G}$ 52, Alsace, French Administrator of Sine-Saloum Protectorate, to Aubert ( $\mathrm{n}^{\circ}{ }_{5} 60$ ), 9 June 1898 ; ANs, GGAOF, Fonds Ancien, $13 \mathrm{G} 5^{2}$, Noirot, 
Some chiefs, who were former veterans and warriors of the French campaigns, encountered great difficulties as they were challenged under ethnic labels. Thus, Ismailla Diop was indeed frowned upon by the Sereer-speaking populations of Joal. On religious terms, Diop was a Muslim who had to rule over Joal's Christian community; but he was also attacked by the locals as a 'Tukulor', a 'foreigner' who did not belong to the local community. However, after 'traditional' rule had become established in the Joal region, the 'Tukulor' identification of chiefs originating from the north of Senegambia ceased to be discussed on the Petite Côte. ${ }^{118}$ It only reappeared, in some cases, in the late 1940s, when the macro-political configuration in Senegal had again changed.

Situations in which parties nonetheless referred to arguments of group affiliation, include questions of commercial rights and licenses, applications for administrative posts open to African candidates, and land disputes. The case of 'foreign merchants' was quite typical. In certain circumstances, chiefs and rich planters in coastal Senegambia attempted to profit from ethnic arguments sustained by the colonial discourse. Those chiefs held that it was more appropriate for their communities to sell to particular persons from their own ethnic grouping. Such strategies worked to exclude 'foreigners' to the advantage of family members or clients. However, under colonial rule it was Lebanese traders who took over much of the retail commerce, and local rulers came to terms with those conditions. ${ }^{119}$

Furthermore, in the case of local quarrels for chieftaincies, it also remained a typical strategy of local pretenders to argue from the perspective of their 'land of origin'. Such quarrels became more infrequent in the course of the first half of the twentieth century, with the creation of the structures of the colony of Senegal being largely completed, but they did not entirely disappear. In 1955, Sada Maka Sy, an infamous commercial agent, petitioned for obtaining a chieftaincy in Goudiry in Senegal's east, arguing that the canton in question was his home region, and that he was descended from the former ruling dynasty. ${ }^{120}$

Land disputes were a problem in many zones which had shortly before come under French 'protection', as in the Gossas region of the old kingdom of

District Commissioner of Sine-Saloum, Bulletin Individuel de Notes [Madiouf Diouf] (without number), without date.

118 ANS, GGAOF, Fonds Ancien, 13 G 52, Alsace, Bulletin Individuel de Notes [Ismaüla Diop] (without number), 25 April 1898, 1.

119 ANS, $11 \mathrm{D} 1 / 960$, Momar Fall, delegate of the inhabitants of Louga, to the President of the General Council of Senegal (without number), 27 December 1946.

120 ANS, 11D1/1059, Sada Maka Sy to Jourdain, French Governor of Senegal (without number), 7 April 1955 . 
Bawol. Occasionally, the ethnic issue was exploited during those disputes, in particular if ethnic argumentations were a useful strategy to counter claims that referred to the traditions of the pre-colonial states. To give one example, when Mamadou Seck, a wealthy merchant, bought a licence to exploit as his property a number of fields he had acquired in the village of Thiénaba, he ran into serious difficulties with the locals. A group of Sereer-speaking cultivators, led by a certain Khaly M'Boup, contested the rights of 'the Wolof' Seck. The latter had bought his land title from the Buur Siin Koumba Ndoffène Fa Mak Diouf: he thus based his claim on the historical rights of the pre-colonial states. His opponents emphasised their 'Sereer identity', and argued that only the 'sons of the region' should have the right to own land. This created an 'authentic' claim, which was older than any transactions made with a dynasty of questionable rights. M'Boup and the other claimants insisted that the rulers of Siin were a clan of 'strangers' and non-Sereer. ${ }^{121}$

During most of the operations involving the reorganisation of political rule under the nascent colonial state on the Petite Côte, transforming the former rule of states such as Bawol, Siin or Saluum, one notion of ethnic sentiment remained, nevertheless, notably absent: 'Wolof identity' was not a major criterion for Wolophone populations to define themselves in dealings with the colonial authorities. The label of 'Wolof' was nearly exclusively employed by non-Wolophone populations, including in their mobilisation against traders, former mercenaries, and Murid marabouts.

Many members of these groups were selected and installed as chiefs of communities or obtained private control over local land. ${ }^{122}$ Sereer-speakers of the whole of the Petite Côte reacted swiftly and aggressively to this perceived threat. In 1905, representatives of various Sereer-speaking communities complained bitterly to the Resident of the 'Sereer Countries' in former Bawol, Jacques, that they were now subject to an 'invasion' of 'Ouoloffs' from the region of the Gandiolais in the north. The Sereer-speakers thus described themselves as 'autochthons', and condemned Wolophone newcomers as 'intruders'; they demanded from the French a substantial change in colonial organisation. ${ }^{123}$

121 ANS, 11Di/96o, Administrator of Subdivision of Moyen-Saloum to District Commissioner of Sine-Saloum, Réclamation Daouda M'Baye (n 2652/MS.), 30 Dec. 1936.

122 Moitt, Bernard, 'Peanut Production, Market Integration and Peasant strategies in Kajoor and Bawol before World War II', in Charles Becker, Saliou Mbaye, and Ibrahima Thioub (eds.), AOF: réalités et héritages: Sociétés ouest-africaines et ordre colonial, 1895-1960 (Dakar: Direction des Archives du Sénégal, 1997), 577-92, 585-7.

123 ANS, 11D1/1348, Jacques, Deputy Administrator of Thiès, Resident of Pays Sérères, Rapport sur la tournée effectuée à travers les Provinces Sérères (du 13 au 21 Mars 1905) par 
However, those tensions in the region disappeared rather quickly in the post-conquest period. This is particularly visible in the case of the new Wolophone paramount chief in Nianing, Abd-el-Kader, who had initially had great problems in making himself accepted as chief. After 1912, his enemies ceased to be Sereer-speaking community leaders. Like in Fatick in the 1880s, the opposition movement against the important Wolophone chief consisted of the Wolophone elite, and was led by a Wolof-speaker, Babakar M'Bodj, who was an employee of the commercial house Maurel \& Prom. M'Bodj saw his chance to win over a group of Sereer followers through an outright invention of tradition; he hired gëwël (griots) to establish a proper genealogy that included Sereer antecedents, to win local Sereer support. ${ }^{124}$ In the end, nevertheless, this was insufficient to mobilise the Sereer-speakers against a ruler who had learned to show sufficient regard for the interests of the rural populations. The year 1912 therefore marked a turning point in the relations between Wolof-speakers and Sereer-speakers in Nianing.

The community of the Pulaar-speaking Fulbe ('Pël') was excluded from this process of diminishing inter-group violence. In the second half of the nineteenth century, they had advanced as cattle-breeders and warriors in zones under French control, and were described as a clear 'other' by all the other communities and the colonial rulers themselves. ${ }^{125}$ Under the rule of Kajoor, the Fulbe populations had come to be administered by a political official whose post had been created specifically for their control: the post of the diahigué. In the state of Kajoor, during the second half of the nineteenth century, and notably in the regions of Kaël and Kantar, this post had become a sinecure for aged ceddo warriors. ${ }^{126}$ The sense that 'the Fulbe' were distinctive continued after the French conquest.

Similar mechanisms can be demonstrated for the Laobe, a community that probably did not claim to be an ethnic group in its own right in the nineteenth century, but presented itself as a community of professional specialists. ${ }^{127}$ In Kajoor, the Laobe had a chief of their own installed by the Damel. Under French administration, this post remained, like the diahigué, a reward for successful and loyal Wolophone warriors. Ogo Yoro, who was the last of those

l'administrateur L. Jacques adjoint au Commandant du Cercle de Thiès (without number), 7 April 1905, 33.

124 ANS, $11 \mathrm{D} 1 / 1357$, Marcel de Coppet, District Commissioner of Thiès, Situation Politique pendant le mois de Juillet 1912 (without number), 1 Aug. 1912, 1.

125 Dupire, Marguerite, 'Réflexions sur l'ethnicité peule', in Itinérances...pays peul vol. 2 (Paris: Mémoires de la Société des Africanistes, 1981), 165-81.

126 ANS, G GAOF, Fonds Ancien, ${ }_{13} \mathrm{G}_{51}$, Rocaché, Bulletin Individuel de Notes [Bä̈do Guèye, diahigué des peulhs du Kaël et du Kantor] (without number), without date.

127 Diouf, Kajoor, 49. 
'chiefs of the Laobe', was removed in 1902 because of illegal tax demands which he had forced his subjects to accede to. Only then did the French decide to abolish the chieftaincy altogether. ${ }^{128}$

On the Petite Côte, Fulbe cattle-breeders were less prominent than they were in the interior provinces of Kajoor, but both the Buur Siin and the Buur Saluum had 'Pël regiments'. 129 The early phase of French rule in the region was characterised by an influx of cattle herds from the Fuuta Tooro profiting from French protection on the coast. This led to conflicts in several zones, notably in the region of Popenguine. ${ }^{130}$ The sentiment of strong difference, formulated by Wolof and Sereer-speakers on the Petite Côte towards Fulbe communities at this particular time, is still very present in oral testimony. ${ }^{131}$ Eventually, the fact that the Sereer-speakers appear to have been traditionally regarded by the Fulbe as both allies and potential slaves may have exacerbated those tensions. ${ }^{132}$

We have little information about the motivations that underlie conflicts between Fulbe and other communities in the Petite Côte region. Comparison with the north and north-east of the new Colony of Senegal, for which documentation is better, helps to explain some conflicts. ${ }^{133}$ French administrators were convinced that the pattern of these conflicts was similar in the different regions. Clashes between sedentary groups and Fulbe herdsmen were very frequent in the territory of the former pre-colonial state of Jolof, specifically in the region around the city of Louga. Bouna N'Diaye, the chief of the province, attempted in 1913 to muster French support against the evasiveness of the Fulbe who migrated between Jolof and Gët (Guet) (a former province of Kajoor

128 ANS, GGAOF, Fonds Ancien, ${ }_{13} \mathrm{G}$ 51, Ferrenes, Administrator-Resident of Thiès, Enquête sur les faits reprochés à Ogo Yoro chef des Laobés (without number), 30 Aug. 1902; ANS, G GAOF, Fonds Ancien, ${ }_{13}$ F $_{51}$, Vienne, Administrator of Thiès, to Director of Native Affairs of the Government-General of French West Africa, Remplacement des chefs convaincus de détournements $\left(\mathrm{n}^{\circ} 145\right), 27$ Oct. 1902, 1-2.

129 ANF, Papiers Ernest Noirot, 148/AP/3/1/4, Noirot to De la Mothe, Governor of Sénégal, Rapport sur la participation des contingents du Saloum à la campagne dirigée contre le Bourba Djiolof (without number), without date, transcription in Martin, Becker, and Mbodj (eds.), 'Documents', 45-6.

130 ANs, 11D1/1348, Jacques, Adjunct Administrator of Thiès, Resident of Pays Sérères, Rapport sur la tournée effectuée à travers les Provinces Sérères (du 13 au 21 Mars 1905) par l'administrateur L. Jacques adjoint au Commandant du Cercle de Thiès (without number), 7 April 1905, 33-4.

131 Interview with Ajjumà Niane, village chief of Niack-Sérère, 1 February 2008.

132 On the 'traditional' perspective of Fulbe informants on the Sereer, see Monteil, Charles, 'Réflexions sur le problème des Peuls', Journal de la Société des Africanistes 20(2), 1950, 153-92.

133 Weicker, Martin, Nomades et sédentaires au Sénégal (Dakar: ENDA, 1993), 52. 
now transformed into an administrative canton) and thereby escaped their tax obligations..$^{134}$

Group conflict between Fulbe and other communities remained a typical factor for the whole of the colonial period. The enraged Wolophone aristocracy ruling over the different provinces of the region repeatedly discussed with French officials what they described as a hereditary conflict with the 'Pël'. ${ }^{135}$ In this context, the 'Fulbe' were more easily targeted than 'the Sereer' on the Petite Côte: they evaded the disciplinary measures mobilised by the state, and their ways of life questioned the legitimacy of the state structures the colonial system had recreated.

Ironically, the outcome of this conflict was far from what the paramount chief of Jolof had wished to obtain. The French administrator concluded that if the 'Pël' were so different from Wolof culture, they had to be protected and administered separately! In the province of Jolof, the French thus nominated two 'tribal leaders', who subsequently stabilised their position by helping the administration to recruit Pulaar-speakers as soldiers for France's Moroccan campaign and the First World War. ${ }^{136}$ The colonial state took those accounts as a reason to redefine structures through ethnocultural 'traditions'.

The political organisation of Senegal under established colonial rule illustrates the absence of a formulated 'Wolof' group identification. When it came to declaring his case for obtaining a local chieftaincy in the area of the Petite Côte, Omar Bayo Fall, member of a notable family from the surroundings of Diourbel, did not refer to being Wolof. He argued from the platform of the particular origins and claims of his family. Consequently, the term 'Wolof' does not even once appear in the French administrative documents commenting on this application.

Although descended from dynasties of Wolophone dignitaries, Omar Bayo Fall showed no interest in pointing out the ethnic side of his family links. He could indeed claim descent from Ely Manel Fall who had once ruled the canton of M'Bayar in the Diourbel region and the province of Bawol Oriental. Still more important, however, from the dynastic point of view, Ely Manel Fall's granduncle had been Meysa Tend Joor, who had been Damel of Kajoor and Teeñ of Bawol at the same time. This ruler was, still in the 1940s, described by both the French and the Wolophone elite as the 'last great king of Senegal'.137

134 ANS, 10D4/11, Administrator of Louga, Situation politique (without number), 1 June 1913.

135 ANs, 10D4/11, Administrator of Louga, Situation politique (without number), 1 March 1913.

136 ANs, 10D4/11, Administrator of Louga, Situation politique (without number), 1 Nov. 1912, 1-2.

137 ANs, 11D1/95, Omar Bayo Fall, Notice de Renseignements (Article 12 de l'Arrêté 1688 APA. du 17.7.43): Candidature: Chef Adjoint du M'Bayar (without number), 25 Feb. 1947; ANS, 
Wherever this was in any way possible for the Wolof-speaking claimants, the reference to the pre-colonial states was, henceforth, the most popular way to claim political rights.

In a similar case, Ely Manel N'Diaye, son of Kode N'Diaye and chief of the 'mixed' canton of Diaganiao (settled by both Wolophone and Sereer-speaking populations) had to explain his origins to French officials. He could boast of being a grandson of Sanor N'Diaye, the ex-ruler of the Diobass and ally of the French in the conquest of the Siin-Saluum region. Ely Manel N'Diaye sustained the heritage claim of his dynasty to bolster his own claims half a century afterwards - without ever insisting on its ethnic characteristics. ${ }^{138}$

During most of the nineteenth century, and well into the first half of the twentieth century, Wolof-speaking communities and their leaders thus show no inclination to insist on their 'Wolof identity'. This does not mean that the concept of 'being Wolof' did not exist. As we have seen, individual leaders could, on particular occasions, resort to this concept. However, it is likely that they only did so when a conflict did not leave any other reasonable course of action: other categories such as religion and loyalty to the local community, but also and essentially allegiance to the local state (even if it was a ceddo state relying in part on plunder), normally played the more important role. In the phase after the French conquest, state functions were taken over by the colonial state. Wolophone elites were very prominent on the colonial side: many Wolophone individuals accepted the new principles of the local order as favourable, and also decided they did not need the identification as 'Wolof' in political life.

An exception were the clashes between Wolophone peasants and Fulbe cattle-breeders that appear as 'ethnicised' conflicts over the whole of Senegal's colonial period. However, they were strictly limited to certain contact zones, although they did not disappear over time. ${ }^{139}$ It is thus useful to mention here

11D1/95, Frament, Administrator of Subdivision of Diourbel, Notes de l'Administrateur (without number), without date.

138 ANS, 11D1/1393, Lemoine, Administrator of Subdivision of M'Bour, Notes sur la Manière de Servir de N'Diaye Ely Manel Chef de $9^{e}$ classe (without number), 31 March 1953, 1.

139 ANS, GGAOF, $17 \mathrm{G} 90$, Berthet, Director of Political Affairs of the Government-General, to Le Coppet, Governor-General of French West Africa $\left(\mathrm{n}^{\circ} 2811 / \mathrm{AP} / 2-1\right)$, Rapport sur l'activité de la Direction Politique (Décembre 1936-Décembre 1937), 22 Nov. 1937, 13; CADN, Fonds 'Anciennes Colonies', Fonds Dakar, 193, District Commissioner of Linguère, Situation Politique du Cercle de Linguère (without number), without date, 1; Guèye, Mamadou Bara, Conflicts and alliances between farmers and herders: a case study of the 'Goll' of Fandène village, Senegal, translated by Jean Lubbock (London: International Institute for Environment and Development (IIED), 1994), 5-6. 
a spectacular climax of such conflicts: the battle between the two villages of Vereck and Kër Matar Binta in $19555^{140}$ This physical battle followed a longlasting land dispute. The cattle breeders of Vereck claimed the (re-)possession of a strip of land that belonged, through cession, to the neighbouring peasant village, which specialised in peanut and food cultivation. ${ }^{141}$ The inhabitants of Vereck, being in an unfavourable legal position, demanded access to the land on the grounds of first ownership as 'Pël autochthons', i.e. the 'real natives' of the land. ${ }^{142}$ They affirmed that the 'others', the 'Ouoloffs', had never had any historical claim to the land. Also, the tomb of Damba Gagne Peinda, Fulbe leader and warrior, was said to be situated under a tamarind tree on the land in question. ${ }^{43}$

In 1955, the low-key conflict transformed into a violent battle over the disputed land, in which ethnic mobilisation was the exclusive strategy of the cattle-breeders. By contrast, the mostly Wolophone populations of Kër Matar Binta emphasised not their ethnocultural but their religious identification. The cleric, Ady 'Hajj' Touré, who was a Muslim leader belonging to the Tijaniyya brotherhood and a Fulfulde-speaker, had on earlier occasions been the mediator between the two communities. Now he was rejected as an arbiter by the peasants of Kër Matar Binta, who demanded that a Murid cleric should lead the negotiations. ${ }^{144}$ The different interests at the heart of the conflict led to a complex mixture of religious versus ethnocultural claims of mobilisation, which made mediation difficult and kept the conflict alive for years to come. ${ }^{145}$

Such conflicts between 'Pël' and 'Murids' were still rather frequent in the 1950s. While we find other violent encounters, as, for example, between Fulfulde-speaking herdsmen and Tukulor or Sarakole settlers, Wolophone

140 ANS, 11D1/960, Telegram from Administrator of Subdivision of Darou-Mousty to Amouroux, District Commissioner of Louga (without number), 6 April 1955.

141 On the principal specialisation of rural Wolophone populations in the profession of peanut planters, see Ross, Clark G., 'A Village Level Study of Producer Grain Transactions in Rural Senegal', African Studies Review 25(4), 1982, 65-84, 68.

142 ANs, $11 \mathrm{D} 1 / 960$, Amouroux to Jourdain, Governor of Senegal, Rixe entre Peulhs et Ouoloffs du 7 Avril 1955 Région Darou-Marnane ( ${ }^{\circ}$ 147/C), 15 April 1955.

143 ANS, $11 \mathrm{D} 1 / 960$, Sall Massamba Kangué, chief of canton of Guet, to Amouroux $\left(\mathrm{n}^{\circ} 511\right)$, 7 April 1955, 1-2.

144 Glover, John, “The Mosque is one thing, the administration is another": Murid Marabouts and Wolof Aristocrats in Colonial Senegal', International Journal of African Historical Studies 33(2), 2001, 351-65.

145 ANS, 11D1/960, Officer of Muslim Affairs in Senegal, Note sur l'affaire de Keur Matar Bineta (Ouoloffs) contre Véreck (Peulhs) (Compte-Renduverbal de l'Officier des Affaires Musulmanes à son retour de tournée) (without number), without date, $1-2$. 
peasants were very frequently seen as the 'natural opponents' of the Fulbe cattle-owners. ${ }^{146}$ We learn from El Hajj Mustapha Sarr, a Murid cleric in Guinguinéo, that in the village of M'Baré-Banth in Waalo, a similar dispute led to constant violence between the Wolof-speaking planter and landlord Mamadou Boy and his agricultural workers on the one hand, and Fulbe cattlebreeders on the other. ${ }^{147}$ Ethnic terms were rendered particularly attractive by the fact that the Fulbe as a group continued to be underrepresented in the political structures of the colonial administration, and felt marginalised within the colonial state.

However, where Wolof-speaking populations had no immediate conflict with Fulbe groups, the situation under colonial rule was less clear. For example, Celle N'Diaye, son of the deposed Buur N'Jambur - the former regional 'governor' under the Damel of Kajoor - Birima N'Diaye, who had erected a sort of autonomous administration in his region, claimed to be the head of a dynasty which had ruled in the region since 1882 , and he challenged the canton chiefs whom the French had installed. Indeed, Sidy Khouya Diop of DiadjOulingara and Cheikh Toko Diop of Nar-Niomré complained bitterly about the patronage network which N'Diaye employed. The latter made it clear that his protection was built on the 'tradition' of the pre-colonial state, which was not only created for the 'Wolof', but also for the 'Fulbe'.148

In the end, the colonial state partly reiterated those pre-colonial state structures. While all of the states ruled by Wolophone leaders formally disappeared with the French conquest, chiefs retained important prerogatives, at least from the perspectives of the ruled subjects. As Wolophone individuals were favoured for the respective posts, many readily relied on those new structures, using them as had been the case with functions and posts inside the pre-colonial

146 ANS, 11D1/973, Plan de Protection [du Territoire du Sénégal]: Chapitre II: Hypothèses (without number), without date [1957], 11.

147 ANS, 11D1/96o, El Hadj Moustapha Sarr, marabout in Guinguinéo, to Jourdain, French Governor of Senegal (without number), 4 Feb. 1955.

148 ANS, 11D1/96o, Birima Cellé N'Diaye to Quinquaud (without number), 7 May 1938, 1-2; ANS, $11 D 1 / 960$, B. Cellé N'Diaye, cultivator at Oulingara N'Diaye, Canton of DiadjOulingara, Cercle of Louga, to Deschamps, French Governor of Senegal (without number), 21 May 1943, 1-2; ANS, 11D1/96o, District Commissioner of Louga, Résumé de l'Affaire Birima Céllé N'Diaye c/Sidi Khouya Diop (without number), 27 Jan. 1939, 1-2; ANS, 11D1/96o, Procès-Verbal d'audition de Témoin, Affaire Sidi Diop et Birima Cellé n'Diaye (6), 1-2; ANs, 11D1/96o, Procès-Verbal d'audition de Témoin, Affaire Sidi Diop et Birima Cellé n'Diaye (1) (without number), without date. 
states. These new structures were independent of ethnic terms. ${ }^{149}$ Moreover, in urban environments, Wolof-speakers often appeared as 'assimilated' Senegalese, and they pointed out their Frenchness. ${ }^{150}$

After the First World War, the importance of ethnic affiliation in Senegal appeared to grow, as many French officials wished to create an 'appropriate administration', conceived on ethnic terms, and they engaged ever more strongly in the collection of information and 'traditions'. The attempt to write, from the end of the 1920 and mostly in the 1930s, reliable codices 'of native customs', is part of this initiative. ${ }^{151}$ In these monographs, which were potentially useful for legal decisions, the administrators assembled data about what they held to be the mechanisms of ethnic group organisation. Although the risk of misunderstandings was considerable, these works give important information about perceptions. They illustrate how Wolophone (and Sereer-speaking) populations of the colony, among others, 'sold' - or described - their group characteristics in conversation with the administrative staff.

In the administrative cercle of Thiès, French administrators realised that 'the Sereer' were considered to be eternally 'turbulent' and 'savage' by the Wolophone chiefs - the years of colonial rule did not change anything in this respect. By contrast, the Wolophone populations were characterised as 'repressive' by Sereer-speakers. The French officials believed that these negative opinions and stereotypes were the fruit of 'an animosity that continues to exist', a type of eternal, primordial hostility. ${ }^{152}$

149 Gastellu, Jean-Marc, 'Politique coloniale et organisation économique des pays serer, Sénégal, 1910-1950', in Charles Becker, Saliou Mbaye, and Ibrahima Thioub (eds.), AOF: réalités et héritages: Sociétés ouest-africaines et ordre colonial, 1895-1960 (Dakar: Direction des Archives du Sénégal, 1997), 564-76, 569-71.

150 ANS, $11 D_{1} / 1303$, Administrator of Subdivision of M'Bour to District Commissioner of Thiès, Remplacement Socé Fall Chef Canton M'Bayar Nianing $\left(\mathrm{n}^{\circ} 205 / \mathrm{C}\right), 28$ December 1945, 1; Austen, Ralph, 'Interpreters Self-Interpreted: The Autobiographies of Two Colonial Clerks', in Benjamin N. Lawrance, Emily Lynn Osborn, and Richard L. Roberts (eds.), Intermediaries, Interpreters, and Clerks: African Employees in the Making of Colonial Africa (Madison: University of Wisconsin Press, 2006), 159-79, 166.

151 Ginio, Ruth, 'Negotiating Legal Authority in French West Africa:The Colonial Administration and African Assessors, 1903-1918', in Benjamin N. Lawrance, Emily Lynn Osborn, and Richard L. Roberts (eds.), Intermediaries, Interpreters, and Clerks: African Employees in the Making of Colonial Africa (Madison: University of Wisconsin Press, 2006), 115-35, 124-5.

$15^{2}$ ANs, $10 \mathrm{D}_{5} / 12$, Administration of Cercle of Thiès, Coutume des Sérères Nones (without number), without date. 
The Sereer, being strongly represented (if not over-represented) in the collection of colonial data, remained nonetheless enigmatic from the point of view of the French officials. Intra-group differences posed a strong problem. Thus, even though an important criterion of 'Sereer-ness' seemed to be matrilineal group organisation, it was exactly the Sereer-Noon - apparently the most prototypically 'Sereer' of all those communities - that did not correspond to this pattern, as they favoured a patrilineal community organisation!153

Through the codices, French administrators arrived in the end at questions of pre-colonial state organisation and its heritage. In their monograph on the 'Ouoloffs de Cayor', the officials of the Thiès cercle (district) commented that some chiefs, being descendants from the traditional families of royal slaves, were actively insisting on the prerogatives their families had won through participation in state structures. This helped them demand, quite successfully (if entirely illegally), the asaka from the local peasants: a tithe of the yearly harvest. ${ }^{154}$ While the French officials had found rather a lot to say on the different groups classified as 'Sereer', they felt unsure about 'Wolof culture'. In respect to the ethnic census of the cercle of Thiès carried out in December 1932, those officials commented that discussing 'the Sereer' was far more interesting than discussing 'the Wolof'. Although the latter group represented more than fifty per cent of the cercle's inhabitants, according to the colonial census data, it was held that 'the Sereer' were far more 'significant' as a group than the Wolophone populations! ${ }^{155}$ The French administration had visible difficulties in defining Wolof cultural group identification, given its denial of ethnic criteria.

This picture was different in zones where Wolophone rulers had only obtained a real foothold in the course of the French wars of conquest, as in the Wuli and in other parts that were to become the cercle of Tambacounda. ${ }^{156}$ In Siin, the context of classifying local populations was also more complex: while French administrators were tempted to depict the old pre-colonial state as 'Sereer', they came, repeatedly, to the very confusing conclusion that most of

153 ANS, 10D5/12, Monographie des Sérères Nones: Les Nones (without number), without date, 7-9, 14; ANs, 10D5/12, Coutumes des Sérères N'Doute (without number), without date, 2, 5, 7 .

154 ANs, $10 D_{5} / 12$, Administration of Cercle of Thiès, Cercle de Thiès: Coutume des Ouoloffs du Cayor (without number), without date, 14.

155 ANS, 10D5/12, Administration of Cercle of Thiès, Codification des Coutumes Indigènes: Coutume Sérère (Exécution Circulaire 128 B.P. du 19 Mars 1932 de M. le Gouverneur Général de l'Afrique Occidentale Française) (without number), without date, 1.

156 ANs, 10D5/12, Hamidou Sy, Commis expéditionnaire à la Résidence de Tambacounda, Essai de monographie du pays qui forme le cercle Tambacounda établie par le Commis expéditionnaire Hamidou Sy - Prescriptions Circulaire $N^{\circ} 234$ AI du 25 Octobre 1930 (without number), 7 Feb. 1939, 2-4. 
the Wolophone chiefs now, in the 1930s, claimed to be the heirs of the ancient state. ${ }^{157}$ The cultural influence of Wolof-speakers in the pre-colonial state was so subtle that at first glance it remained unnoticed by the agents of the colonial power.

The information assembled by the French did not lead to many concrete results, although it did provoke French interference in the structure of the councils of dignitaries. On the level of political organisation, we definitely find few references to ethnic affiliation, either by the French administrators and or by their local informants. Only in Dagana and adjacent cantons did African collaborators of the administration argue with the classifications of 'ouolof' and 'peul'. Given the fact that Dagana is to be found at the margins of the former pre-colonial state structures, and that the abovementioned regular conflicts between Pulaar-speaking cattle breeders and Wolophone peasants had a particularly strong impact in this region, the recourse to ethnic distinctions corresponded to a certain logic. ${ }^{158}$

In the southern district of Kaolack - in the former region of the pre-colonial state of Saluum - some individuals holding leading positions in the 'traditional' hierarchy were referred to as being 'ouolof' or 'sérère'. French administrators were, however, mostly interested in a former state that had had a very complex set-up of different 'nobilities'.159 For the other district reports there is no indication at all of a possible allegiance of councillors to particular ethnic groups. This includes the cantons close to the Petite Côte at the margins of the former pre-colonial states of Bawol and Siin before $1945 .{ }^{160}$

157 Moreover, reports pointed repeatedly to tensions between inhabitants of former Siin and former Saluum, which remained hostile to each other, even with the official disappearance of the states in question. See CADN, Fonds 'Anciennes Colonies', Fonds Dakar, 293, Gautier, Annexe concernant les Terres « Sérère - Sine » du Canton de Gossas (without number), without date [1957], 5; ANS, 10D5/12, Coutume Sérère (Région du Sine): Exécution de la circulaire $n^{\circ} 128$ AP. du 19 Mars 1931 de Monsieur le Gouverneur Général (without number), without date, $1-9$.

$15^{8}$ ANS, $10 \mathrm{D} 1 / 36$, Philippe, Administrator of Subdivision of Dagana, to District Commissioner of Bas-Sénégal, Conseil des Notables $\left(\mathrm{n}^{\circ} 74 / \mathrm{C}\right), 6$ Dec. 1947.

159 ANS, $10 \mathrm{Di} / 36$, Administrator of Subdivision of Foundiougne to District Commissioner of Kaolack ( $\mathrm{n}^{\circ}$ 241), 12 Sep. 1947; ANS, 10D1/36, Administrator of Subdivision of Foundiougne to District Commissioner of Kaolack, Renouvellement Conseil Notables ( $\left.\mathrm{n}^{\circ} 315\right), 17$ Nov. $1947,1-2$.

16o ANS, 10D1/36, Glangeaud, Administrator of Subdivision of Guinguinéo, to District Commissioner of Kaolack ( $\left.\mathrm{n}^{\circ} 1764\right), 15$ Nov. 1947, 1-2; ANS, 10D1/36, Administrator of Subdivision of Kaolack, to District Commissioner of Kaolack and Wiltord, Governor of Senegal (without number), 6 Nov. 1947; ANS, 10D1/36, Lhomme, Administrator of Subdivision 


\section{Elections, New Spoils, and the Flaring Up of Ethnic Struggle: Senegal in the Late Colonial Phase, $1945^{-1960}$}

The remarkable absence of ethnic categories within the group of Wolophone inhabitants of Senegal was subject to serious challenges in the 1940s. Politically, the end of the Second World War opened up new horizons. A phase of intense reform within the French colonial system led to the creation of new political roles for local and territorial elites, including as elected councillors at different levels, accompanied to a greater or lesser degree by privileges. The local chiefs, moreover, now enjoyed access to larger funds, distributed through the French economic modernisation programmes. This made the posts even more inviting.

Quite visibly, the Vichy experience and the subsequent phase of, first, war economy and, then, liberalisation profoundly changed the political framework in which ethnic solidarity was defined. ${ }^{161}$ For Senegal, this meant from 1944 that apart from the particular rights of the inhabitants of the Quatre Communes, larger groups of Senegalese inhabitants now became entitled to vote. The number of enfranchised persons rose from election to election. The voters decided, among other issues, upon Senegalese deputies for the French National Assembly (one for the 'citizens' of the Quatre Communes, one for the bulk of Senegal's colonial populations living outside of this circumscribed area), and they elected delegates for a territorial council. These territorial councils were concerned with questions that directly affected local life. ${ }^{162}$

At first glance it seems as if the changes of 1944/45 were destined to have little impact on group sentiment. After all, before the more profound reforms towards semi-autonomy voted through the loi-cadre of 1956, the prerogatives of the new posts were, usually, only consultative. ${ }^{163}$ This fact, however, did not really diminish the attractiveness of the position of deputy. These positions were an ideal platform for the creation of patronage networks, which allowed the delegates to mobilise resources via their territorial and inter-territorial

of Fatick, to District Commissioner of Kaolack, Renouvellement Conseils Notables. $\left(\mathrm{n}^{\circ}{ }^{1848}\right)$, 12 Nov. 1947, 1-2.

161 Ginio, Ruth, French Colonialism Unmasked: The Vichy Years in French West Africa (Lincoln - London: University of Nebraska Press, 2006), 182; Lawler, Nancy, 'Reform and Repression under the Free French: Economic and Political Transformation in the Côte d'Ivoire, 194245, Africa 6o(1), 1990, 88-110, 94-8.

162 Chafer, Tony, The End of Empire in French West Africa: France's Successful Decolonization? (Oxford: Berg, 2002), 61-4, 74-5.

163 On the loi-cadre, see Chafer, End, 166-7; Keese, Alexander, "Quelques satisfactions d'amour-propre": African elite integration, the Loi-cadre, and involuntary decolonisation of French Tropical Africa', Itinerario 26(1), 2003, 33-57, 42-4. 
parties, and it helped them build a reputation with the European administrators. Being gatekeepers and brokers of contacts with the colonial rulers, the councillors rapidly came to enjoy a considerable prestige. Their position was, in theory, a direct threat to the power of the chiefs who had formerly strongly monopolised access to the upper echelons of the colonial hierarchy, together with the African employees of the same administration. In the end, however, both concepts continued to exist in Senegal up to the political threshold of independence: the chiefs found themselves patrons among the councillors, and the councillors sought to bolster their own prestige with that of having chiefs as clients. Occasionally, they would even attempt to bring about the installation of a family member to the post of an important chef de canton. ${ }^{164}$ This increased the material attraction of the chieftaincies.

Moreover, French attempts at democratisation at the territorial level also opened new spaces at the local level: activists called for a position for themselves. Schemes and intrigues endangered the position of some formerly wellentrenched 'traditional rulers' who came under significant pressure. This process included the case of Meïssa Fall, chef de canton of Joal, whose strategies for coping with the challenge will be analysed in detail below.

Many other chiefs also came under pressure: Meïssa Fall's colleague and fellow Fulfulde-speaker, Konko Ciré Bâ, was faced with similar problems, but he was initially successful in dealing with them. His canton, Fandène on the Petite Côte, was, as the French characterised it, a 'mixed canton', mainly peopled by Wolof- and Sereer-speaking populations. Bâ was an outsider from an ethnic point of view: he was 'Tukulor', with a large family in the north of the colony, in the district of Matam. From the 1940s, he was subject to constant pressure from local political activists who wanted to see him removed; nonetheless, he restored his authority and maintained it well into the 1950s. Only in 1957 did the now aged chief lose his standing: his prestige finally evaporated, as a consequence of a revived campaign against his status as 'stranger'. Frustrated, Bâ wished to return to Matam, in his 'region of origin'. Nevertheless, he still attempted, as had been normal in the decades before the Second World War, to nominate a successor of his own choice and from his family. In fact, colonial officials in the region had supported such procedures over the decades since the French conquest, but the political situation had now changed. The French administrators thus felt uneasy about the intentions of the 'foreigner' Bâ.

164 The only comparative study on 'global chieftaincy' is Newbury, Colin W., Patrons, Clients, and Empire: Chieftaincy and Over-Rule in Asia, Africa, and the Pacific (Oxford: Oxford University Press, 2003); see also Keese, Alexander, Living with Ambiguity: Integrating an African Elite in French and Portuguese Africa, 1930-1961 (Stuttgart: Steiner, 2007), 86-91. 
While they sympathised with the goals of their long-standing collaborator, they did not want to enforce a dynastic succession. Thus, in the late 1950s, even the positions of well-established 'traditional rulers' had become difficult to maintain if they were attacked because of their 'origins.' ${ }^{165}$ In 1958, Bâ's family therefore lost the chieftaincy of Fandène.

The upsurge of similar conflicts between different communities included Wolof-speakers and other groups in different regions of the colony after the Second World War. While before the early 1940s, local political power had relied on the pre-colonial states and the colonial order, ethnicity now came back into play. Interestingly, French reports commented that antagonisms of 'ethnic groups' in Senegal had diminished after the Second World War, due to increased contacts between different groups through migration and better lines of communication, particularly between 'Wolof' and 'Tukulor'. It is obvious that labour migration after the Second World War and in the urban areas was indeed an important phenomenon. ${ }^{166}$ However, such reports were generally written in ignorance of the new, political dimension of struggles in the rural communities. Observers from the colonial administration were correct in that there was no ethnicisation of larger territorial politics in Senegal: there was no emergence of 'ethnic parties'. The main political parties in the territory absorbed voters in various regions, although it is true that the Senegalese branch of the Section Française de l'Internationale Ouvrière (SFIO) - for a short period after 1945 being the strongest political party in the whole of the colony - had the particular support of the inhabitants of the Quatre Communes. ${ }^{167}$

From the experiences of the conquest period, Sereer-speakers on the Petite Côte had shown potential for a mobilisation on ethnic terms. Under the colonial regime before the Second World War, we do not find such initiatives by Sereer-speakers. Even after 1945, on the Petite Côte, when Sereer-speaking communities started to migrate in large numbers (particularly to Rufisque, and later on to Dakar), this had little effect. In the urban context, Sereerspeakers avoided forming there a diaspora that would have defined itself through ethnocultural criteria. Consequently, there was no reflux of ethnic

165 ANS, $11 \mathrm{D} / 1382$, Grasset, Administrator of Central Subdivision of Thiès, to District Commissioner of Thiès (without number), 7 January 1959.

166 ANS, 11D1/973, Plan de Protection [du Territoire du Sénégal]: Chapitre II: Hypothèses (without number), without date [1957], 10.

167 The Union des Toucouleurs and the Union des Irlabés remained entirely marginal, see ANS, 11D1/973, Plan de Protection [du Territoire du Sénégal]: Chapitre II..., 11. 
group sentiment back from the urban areas into the coastal region further southwards. ${ }^{168}$

Instead, in the hinterland of M'Bour, Nianing, and Joal, Sereer-speakers employed ethnocultural terms for their regional political goals. As in the two last decades of the nineteenth century, such claims were mostly made in relation to land problems. When on Mar-Lotte Island in the Siin-Saluum delta, a Wolof-speaking merchant purchased a large part of the land and attempted to drive the local peasants from their fields, the whole area became the scene of a dramatic xenophobic outbreak. The locals claimed that, as 'Sereer', they had the obvious entitlement to the land and would not accept the merchant Fabirima Sarr as landowner, as he was a 'stranger' to the country. Agents of the new owner were attacked and wounded. Sarr himself never dared to travel to Mar-Lotte because he feared for his life! 169

Before the mid-1940s, Sereer-speaking populations had rarely challenged the Wolof-speaking paramount chiefs on ethnic terms; now for a while it became frequent. ${ }^{170}$

In the case of the chieftaincy of Diaganiao, where the French administrators had strongly demanded a candidate who would be appropriate from an ethnocultural point of view, the representatives of the colonial government did finally claim they could not find a suitable 'Sereer candidate' for the post. After a hasty quest for reliable information on the attitudes of local populations, they considered that the appropriate candidates were all Wolof-speaking and came from the small group of individuals forming the local elite of merchants, middle-level officials and veterans. Contrary to what the colonial administrators had initially feared, the local populations accepted the procedure employed by the colonial state; there was not the slightest sign of resistance along ethnic lines. ${ }^{171}$ However, Sereer-speakers now emphasised some local cultural traits that were regarded as quite different from 'Wolof customs'. They assembled in secret meetings, from which 'Wolof strangers', even if they were officially powerful, were excluded. This counter-culture was espoused by a

168 ANS, $11 \mathrm{D1} / 1303$, Administrator of Subdivision of M'Bour, Notice de Renseignements concernant le Chef de Canton Sossé Fall - Canton du Bayar-Nianing (Subdivision de M'Bour) (without number), 14 Aug. 1944.

169 ANS, 11D1/1148, Extrait du Rapport $N^{\circ} 56$ IAA du 29 Mai 1953 de Mr. l'Inspecteur des A.A. Le Rolle: Subdivision Fatick (without number), without date.

170 ANS, 11D1/1303, Rey, Governor of Senegal, to District Commissioner of Thiès, Au Sujet Chefferie canton Diaganiao ( $\left.\mathrm{n}^{\circ} 1112 / \mathrm{APA}\right), 30$ June 1941, 2-3.

171 ANS, $11 \mathrm{D} 1 / 1303$, Administrator of Subdivision of Thiès (Guilatteau?) to District Commissioner of Thiès ( $\mathrm{n}^{\circ}$ 2/S.T.), 15 Sep. 1941. 
number of young locals on the Petite Côte and in the Siin-Saluum region, and became stronger after the Second World War. ${ }^{172}$

Over the decades of French rule, obvious networks of patronage and payments had flourished in many of the chieftaincies in the region. ${ }^{173}$ The paramount chiefs had profited from connections they had established with Wolof-speaking merchant families, employing them for their own ends. In particular they attempted to market peanuts from collective fields on their own account, bypassing any community institutions. Such attempts enraged the cultivators and, in the overall atmosphere of reform in the second half of the 1940s, occasional revolts occurred against 'traditional rulers' who had behaved in what was perceived as 'shady' ways. Even formerly powerful rulers like the canton chief, Socé Fall, had to learn that, given the conditions of slow liberalisation of colonial rule, 'their' subjects were no longer disposed to accept exploitative practices. ${ }^{174}$

Existing patronage networks provoked many political problems on the Petite Côte after 1945. As one major example, Kode N'Diaye, the former chief of the canton of Nianing-M'Bayard, had built his network on a strictly personal base. This included individuals from many linguistic groups and avoided 'ethnic patronage.'175 Local headmen, who campaigned against N'Diaye's reinstallation in the 1940s, were mainly Sereer-speakers, but they did not have any ethnic agenda. They attacked what they described as N'Diaye's corrupt character, not his 'Wolofness' or lack of authenticity. ${ }^{176}$

A second similar case is, again, in the canton of Diaganiao, where the election process of a new chief had not led to stable results. Locally, mostly Sereerspeaking populations protested against the behaviour of Wolof-speaking chief

$172 \mathrm{ANS}, 11 \mathrm{D1} / 1303$, Thérond, Enquête sur les incidents qui se sont récemment produits dans le canton de Diaganiao (Cercle de Thiès) ( ${ }^{\circ}{ }^{\circ}$ 29), 4 June 1941, 2-3.

173 After 1958, the chefs de canton were either removed or integrated into regional administrative structures. In the latter case, they were controlled by the prefects and became employees of the post-colonial state; nonetheless, they were still expected to be active in 'native jurisdiction'. See Le Roy, Etienne, 'Lévolution de la justice traditionnelle dans l'Afrique francophone', Canadian Journal of African Studies 9(1), 1975, 75-87, 77-8.

174 ANS, 11D1/1303, Administrator of Subdivision of M'Bour to State Advocate in Dakar, Plainte pour abus confiance contre ex-chef canton Sossé Fall ( $\mathrm{n}^{\circ}$ 104/C.), 29 April 1946, 1.

175 ANS, 11D1/1303, Telegram from Larrue, Administrator of Subdivision of M'Bour, to District Commissioner of Thiès, Retour Codé N'Diaye Canton Diaganao [sic] ( $\left.{ }^{\circ} 23 \mathrm{f} / \mathrm{C}\right), 22$ July 1946; ANS, 11D1/1303, Larrue to Etcheverry, director of journal 'Réveil' (without number), 17 May 1947.

176 ANS, 11Di/1303, Larrue to District Commissioner of Thiès, Codé N'Diaye ( $\left.{ }^{\circ} 23 f / C\right)$, 1st June 1945. 
Ely Manel N'Diaye. Crowds of discontented inhabitants of the canton assembled in front of his residence and demanded his resignation. ${ }^{177}$ Nonetheless, this was not Sereer ethnic xenophobia: N'Diaye had simply gone too far in bribing some dignitaries with gifts of cattle so as to lay his hands on the lucrative export trade in the canton. Moreover, during elections, N'Diaye had supported the SFIO, which by 1951 had cost him the rest of his local support. ${ }^{178}$ Most of the locals were adherents of the Bloc Démocratique Sénégalais (BDS), founded as a split-off from the Socialist movement in 1948 and led by the popular poetpolitician Léopold Sédar Senghor (a 'son of the land'); local BDS militants despised the patronage given by the chief to a Wolof-speaking merchant elite that remained, for a time, linked to the SFIo. ${ }^{179}$

However, despite the ethnic arguments used against him, Ely Manel N'Diaye managed to come to terms with the opposition of a part of the Sereer-speaking populations. As the conflict in Diaganiao was about abuses of power and not ethnicity, N'Diaye obtained the chance to rebuild his reputation - and he took it. On the verge of independence, after an active campaign of courting the canton's populations between $195^{2}$ and $195^{8}$, he again enjoyed the very vocal support of these populations. ${ }^{180}$

The Sereer-speakers in the region of the Petite Côte continued to accept Wolophone candidates for some of the canton chieftaincies. When in the late 1940 s two Wolof-speakers became chefs de canton of important and politicallycontested units - Cheikh Diack in M'Badane-Sassal, and Armand N'Diaye as canton chief of M'Bayar - the Sereer-speakers of the two administrative entities did not attack their nomination, although this would now have been easy. The chiefs satisfied the Sereer-speakers through a moderate political programme, while some local Wolof-speaking merchants and settlers led the

177 ANS, 11D1/1393, Buffet, Administrator of Subdivision of M'Bour, to District Commissioner of Thiès $\left(\mathrm{n}^{\circ} 13^{2}\right), 25$ Sep. 1951, 1.

178 ANS, 11D1/1393, Goujon, Secretary-General of Senegal, to District Commissioner of Thiès, Recensement Diaganiao ( $\mathrm{n}^{\circ}$ 824/APA/2), 7 July 1952, 1; ANS, 11D1/1393, Amelot, Administrator of Subdivision of M'Bour, to District Commissioner of Thiès ( $\mathrm{n}^{\circ} 723 / \mathrm{P}$.), 26 March 1948.

179 CADn, Fonds 'Anciennes Colonies', Fonds Dakar, 197, Cercle de Thiès: Rapport Politique Année 1957 (without number), without date, 4bis-5bis.

180 ANS, 11D1/1393, Buffet, Administrator of Subdivision of M'Bour, Notes sur la Manière de Servir de N'Diaye Ely Manel Chef de $10^{e}$ classe (without number), 14 June 1952, 1; ANS, 11D1/1393, Buffet, Notes sur la Manière de Servir de N'Diaye Ely Manel Chef de $10^{e}$ classe (without number), 7 Jan. 1953, 1; ANS, 11D1/1393, Administrator of Subdivision of M'Bour, Bulletin Individuel de Notes [Ely Manel N'Diaye] (without number), 22 Oct. 1958, 1. 
opposition. ${ }^{181}$ In places where merchant networks were absent, as in the case of the Wolof-speaking canton chief of Thor-Diander (part of the former Jander), a canton dominated by Sereer-speakers, the quest for a modus vivendi was less complicated. Accordingly, the colonial authorities considered Mamadou Fall M'Backé to be a very popular chief, although they found it very surprising. ${ }^{182}$ Whenever the local chiefs conformed to the expectations of their 'subjects', there were few tensions expressed in ethnocultural terms. ${ }^{183}$

In the case of the reinstallation of Socé Fall, this time as canton chief of Nianing, the same mechanisms prevailed. Fall was an heir to the former ruling family of Kajoor, through his connection to the lineage of Amady N'Goni Fall. In his correspondence, he described himself as a member of the family of the Damel, and avoided any reference to being a 'Wolof' ruler. ${ }^{184} \mathrm{He}$ again became chief after promising to give up the abuses that had led to his earlier dismissal. However, as an SFIo follower, he ran into serious trouble with a large group of the Sereer-speakers in his canton. After the sequence of electoral defeats of the SFIO from the end of the 1940s, these protesters increasingly started to attack Fall verbally. In the villages of N'Gaparou and Babel, local unrest created a small but full-scale rebellion. ${ }^{185}$ The Sereer-speakers of Malikunda-Sérère even sent petitions to Senghor's BDS in which their spokesmen demanded Fall's

181 ANS, $11 \mathrm{D1} / 1303$, Administrator of Subdivision of M'Bour, Notes sur la Manière de Servir de Ndiaye Armand Chef de $7^{e}$ classe (without date), without date [1957], 1; ANS, 11D1/1303, Administrator of Subdivision of M'Bour, Notes sur la Manière de Servir de Chef de canton classe du sixième (6 $6^{e}$ [Armand N'Diaye] (without number), 17 March 1958; ANS, 11D1/1303, Administrator of Subdivision of M'Bour, Notes sur la Manière de Servir de Ndiaye Armand Chef de 8 e classe (without number), 31 Dec. 1953, 1; ANS, 11D1/1303, Jean-Louis Clavier, Administrator of Subdivision of M'Bour, to District Commissioner of Thiès, Armand N'Diaye (n ${ }^{\circ}$ 64/C.), 24 June 1949; ANS, 11D1/1303, Administrator of Subdivision of M'Bour, Bulletin Individuel de Notes [Armand N'Diaye] (without number), 20 Feb. 1948; ANS, 11D1/1303, Larrue to District Commissioner of Thiès, Nomination Armand N'Diaye intérimaire M'Bayar-Nianing ( $\left.{ }^{\circ}{ }^{50} / \mathrm{C}\right), 12$ Aug. 1946.

182 ANS, $11 \mathrm{D} 1 / 1303$, Lami, District Commissioner of Thiès, to Bailly, Governor of Senegal ( $\mathrm{n}^{\circ}$ 676/AGC), without date, 1.

183 On M'Backé's successor in 1957, Samba Amadu Diop, see CADN, Fonds 'Anciennes Colonies', Fonds Dakar, 293, Gautier, Note pour Monsieur le Chef du Territoire du Sénégal: Ordre de mission $N^{\circ} 5234$ du 29 Novembre 1957 pour se rendre à Thiès...( ${ }^{\circ}{ }_{15}$ C.IAA/J.I.G.), 19 Dec. 1957, 3 .

184 ANS, 11D1/1303, Administrator of Subdivision of M'Bour, Notes sur la Manière de Servir de Fall Sossé Chef de $6^{\circ}$ classe du Canton de Nianing (without number), 20 March 1958.

185 ANS, $11 \mathrm{D}_{1} / 1303$, Lemoine, Administrator of Subdivision of M'Bour, to Cornut-Gentille, Governor-General of French West Africa ( $\left.{ }^{\circ} 157\right), 25$ Sep. 1953, 1. 
immediate dismissal. ${ }^{186}$ The BDS organised an active movement for his removal, peaking during the electoral campaigns of the early $1950{ }^{187}$ The 'traditional authority' in neighbouring M'Bayar canton, Armand N'Diaye, a BDS party member, did his best to further add fuel to the fire: he discredited his colleague before the colonial authorities through a large number of denunciatory letters. ${ }^{188}$ Even under these conditions, Socé Fall adapted to the changing environment and survived politically. In 1958 he had obviously managed to establish good relations with the many Sereer-speaking personalities dominating village politics. ${ }^{189}$ Only in 1959 did Socé Fall pay the price for his longstanding anti-BDS position: the new leaders of government belonging to the Union Progressiste Sénégalaise (UPS), the successor movement of the BDS, removed him as revenge for his earlier political attitudes. ${ }^{190}$

In view of this last instance, we have to be careful to avoid an impression of an ethnic bipolarity of political parties. It would be incorrect to define, on the Petite Côte and in the Siin-Saluum region, the BDS as the 'Sereer party' and the SFIO as the 'Wolof party'. Among leading Sereer-speaking dignitaries, there was a respectable minority of SFIO supporters and candidates, and the newly appearing 'ethnic' debates of the late 1940s cannot simply be translated into political allegiance. Ethnic terms only entered into the political battle when it was useful on tactical grounds to denounce the 'otherness' of a rival in party competition. ${ }^{191}$ The French administration had, rather clumsily, contributed to creating the opportunities for conflict expressed through such ethnic terms. The colonial village organisation increasingly used ethnic labels: in the 1940s,

186 ANS, 11D1/1303, Socé Fall, canton chief of M'Bayar, to Administrator of Subdivision of M'Bour (without number), 27 June 1951, 1.

187 ANS, $11 \mathrm{D} 1 / 1303$, Goujon, Secretary-General of Senegal, to District Commissioner of Thiès, Chefferies Cantons Nianing et Thor Diander $\left(\mathrm{n}^{\circ}\right.$ 1175/APA/2), 8 Nov. 1951.

188 ANS, 11D1/1303, Socé Fall to Administrator of Subdivision of M'Bour (without number), 26 June 1951, 1-2. On Armand N'Diaye and party politics, see ANs, 11D1/1303, Armand N'Diaye, Chief of canton of M'Bayar, to Administrator of Subdivision of M'Bour (without number), 17 June 1952, 1.

189 ANS, $11 \mathrm{D} 1 / 1303$, Berthet, substitute for Goujon, acting Governor of Senegal, to Administrator of Subdivision of M'Bour ( $\mathrm{n}^{\circ}$ 1616/APA/2), 15 March 1954; ANS, 11D1/1303, Administrator of Subdivision of M'Bour, Notes sur la Manière de Servir de Fall Sossé Chef de $6^{\circ}$ classe du Canton de Nianing (without number), 20 March 1958, 2.

190 ANS, 11D1/1303, Valdiodio N'Diaye, Senegalese Minister of the Interior, Arrêté portant fin de détachement d'un Chef de Canton ( ${ }^{\circ}$ 11261/MINT/APA), 5 Nov. 1959.

191 ANS, 11D1/1303, Lemoine to District Commissioner of Thiès, Chefferie du canton de l'AgaGohé (without number), 21 May 1954, 2. 
more settlements than ever had an 'ethnic name'. ${ }^{192}$ Some of these names had existed under pre-colonial conditions: in the case of the Siin-Saluum region, an ethnocultural form of settlement had had to do with defence against pillaging campaigns of the ceddos of the local states. Some of the inhabitants of socalled 'Sereer', 'Tukulor' and 'Bambara' villages in the area underlined their distinctiveness through the respective names already in existence at the moment of French conquest; and we have references of that type from Boilat's monograph and from reports by early French administrators and Spiritan missionaries. ${ }^{193}$ However, due to the activity of the French administration, such labelling became a normal colonial routine in the interwar period. In the 1940s, we also find a good number of villages labelled as 'Ouoloff'. 194 Even if much of this labelling was due to the interpretation by administrators, such administrative labels proved to be a point of reference that could lead to aggressive group relations and violence.

In contrast to the first wave of violence that had targeted some 'foreign' chiefs on the Petite Côte but had not predominantly relied on ethnic distinctions, the electoral campaign of 1951 antagonised villages under different administrative-ethnic labels. The first to be hit were communities that were smaller and more vulnerable than those of the Sereer-speakers, as in the violence between Malikunda-Sérère and Malikunda-Bambara. The Bambaraspeakers voted by a large majority for the Socialists, which provoked the outrage of the Sereer-speakers of the neighbouring village and developed into a violent struggle for land: the Sereer obviously hoped to expel Bambaraspeakers from the region as 'strangers' and lay their hands on their fields! There were no signs of older tensions: it was only under the impact of post-war political rivalries, orchestrated on the side of the BDs by political envoy Jacques d'Erneville, that Sereer-speaking villagers began to consider the 'alien' character of long-standing neighbours. ${ }^{195}$ In the case of Malikunda and its region, this created unprecedented troubles, which, however, did not lead to the final expulsion of Bambara-speakers.

192 ANS, GGaOf, Fonds Ancien, $13 \mathrm{G} 5$, Alsace to Director of Native Affairs of Senegal $\left(n^{\circ} 455\right), 12$ June 1897 .

193 ANS, 11D/1382, Grasset, Administrator of Central Subdivision of Thiès, to District Commissioner of Thiès (without number), 5 Dec.1958; Boilat, Esquisses, 264.

194 ANS, 11D/1417, Lami, District Commissioner of Thiès, to State Advocate in Dakar, Affaire de M'Badane Sassal (n ${ }^{\circ}$ 401/AGC), 26 Sep. 1950; ANs, 11D/1417, Philippe to Lami, Affaire Cheikh Diack (n 95/C), 25 Sep. 1950.

195 ANS, 11D1/1303, Socé Fall to Administrator of Subdivision of M'Bour (without number), 27 June 1951, 1. 
Such friction was only one possible outcome of administrative situations, and not an inevitable result. In the village and surroundings of Tiamboledj, during the electoral campaign of 1949, the Sereer-speaking village chief Godène Diouf had encouraged the villagers to attack neighbouring settlements that were regarded and labelled as 'Bambara' and 'Wolof'. Godène's own brother, Rok Diouf, distanced himself from the chief and protested against these ethnically legitimated attacks. Obviously, Rok Diouf acted in his own interest: by convincing the locals to resume their allegiance to the Wolof-speaking canton chief, Socé Fall, he also managed in the long run to bypass the dynastic rules of his family. Nonetheless, it remains an important fact that both men, Rok Diouf and Socé Fall, created a workable alliance that functioned even under conditions of ethnic tensions. It brought the former into the position of village chief instead of his brother, and allowed Fall to enlist a group of supporters that had previously been on the verge of challenging his rule over the canton on the ground of their being 'Sereer' and him being a 'Wolof' chief. ${ }^{196}$ This shows that the ethnic terms between 'Sereer' and 'Wolof' could be flexible. The interests of smaller groups and of individuals remained more important than any 'primordial sentiment'; only where it was safe to attack a group on ethnic grounds, and where the antagonism was linked to clear political party opposition, did it remain a continuous phenomenon.

Therefore, even the ethnocultural identifications of smaller groups, like the 'Sereer', were never homogeneous. Oppositions under group labels could be reformulated, as sub-group affiliations were also employed for mobilisation within the Sereer-speaking regions. During 'internal' political struggles in 'Sereer villages' in the second half of the 1940s and in the 1950s, there was no trace of any feeling of solidarity 'between all Sereer'. Most prominently, in parts of the canton of M'Bayar-Nianing, the regional Safèn subgroup of the Sereerspeakers claimed a proper group identity for themselves. As we have seen from the early missionary reports from the Petite Côte, such forms of behaviour were not entirely new, but they now returned with a stronger political impact. The 'Safèn' distanced themselves quite ostentatiously from other groups that were normally all considered 'Sereer'. Thus, it was all the more complicated to turn a joint Sereer identity against Wolophone chiefs. Grudgingly, the representatives of the colonial power reacted to such unwelcome 'complications'. In problematic villages where friction between formerly rather unnoticed 'subgroups' appeared, such as in Kéniabour, the French decided to select diligent

196 ANS, 11 D1/1393, Clavier, Administrator of Subdivision of M'Bour, to District Commissioner of Thiès $\left(n^{\circ} 43 / C\right), 23$ May 1949. 
headmen, like Sindak Dione, as village chiefs, who could exert influence on the 'occasionally turbulent Safèn populations'. ${ }^{197}$

Besides conflicts between subgroups, cleavages between generation sets were another source of conflict that greatly complicated front lines in the 1940s and 1950s. In the village of Godaguène, the (mostly Sereer-speaking) village headmen had forced the Wolophone village chief to resign. As a successor, they agreed on a local, Sereer-speaking candidate. This decision, however, was immediately challenged by a group of young, Sereer-speaking male inhabitants of the settlement, who favoured the return of the dismissed chief who had been considerably younger than the new head of the village! ${ }^{198}$ Hence, in this particular case, aspects of generation overruled ethnic solidarities: the younger generation preferred to have a sympathetic Wolof 'stranger' as village chief to being ruled by a candidate of the elders.

In contrast to changes on the Petite Côte, where the political reforms sometimes favoured a limited return of 'ethnic allegiance' into the political arena, it has to be said that many other parts of the colony remained largely unaffected by such mobilisation strategies. This was particularly the case for the northwestern area of Senegal, where the absence of ethnic arguments is impressive in comparison. The legacy of even stronger former state structures - the uncontested dominance of, namely, Kajoor and Waalo - during the pre-colonial period made it easier for the local rulers to keep any ethnic discussions out of the debate on local power. This was clear for Amadou Salla Diop, the paramount chief of N'Guick. He was accepted as a sufficiently valuable ruler by the local populations despite being a 'foreigner' in his canton, and there was no movement against him that would have been comparable to the 'troubles' occurring temporarily in many places on the Petite Côte. ${ }^{199}$ The key issue was that Diop's family had long held the 'hereditary rights' to the positions in the canton. ${ }^{200}$ The regions north of Louga, called Thiol in Pulaar by the many Fulfulde-speakers settling there, were accepted as the stronghold of the Fall

197 ANS, 11D1/1303, Administrator of Subdivision of M'Bour to District Commissioner of Thiès $\left(\mathrm{n}^{\circ} 2290\right), 4 \mathrm{June} 1943$.

198 ANS, 11 D1/1393, Chief of canton of Diaganiao to Administrator of Subdivision of M'Bour (without number), 2 Sep. 1946.

199 ANS, 11D1/96o, Deschamps, Governor of Senegal, to District Commissioner of Louga (n 891/APA/2), 22 Sep. 1943, 1.

200 ANs, $11 \mathrm{D} 1 / 960$, Telegram from District Commissioner of Louga to Deschamps, Cantons Nord Louga. Désignation nouveaux Chefs du Gandiolais et du Mérina Installation de Chef Intérimaire du K/Bacine ( $\mathrm{n}^{\circ}$ 147/cf), 18 Nov. 1943, 1; ANS, 11D1/96o, Michel, Inspector of Administrative Affairs, Note au sujet des chefferies du Cercle de Louga (lettre $n^{\circ} 100$ du 13 Septembre 43) (nº $78 / \mathrm{IAA}), 15$ Sep. 1943. 
family. ${ }^{201}$ In both cases, the point of reference was clearly the pre-colonial structure of provinces, which excluded any conflict for power on ethnic grounds.

In Kebemer, another canton of north-western Senegal, French officials, in a rigorous inquiry, identified 'Wolof', 'Fulbe', 'Moors', 'Lawbe', 'Sereer' and 'Bambara' populations. ${ }^{202}$ However, what stabilised social relations in Kebemer was its past as part of a province of the pre-colonial state of Kajoor, and as the stronghold of the Sall dynasty - such as in the case of Sangone Sall in the ancient province of Gët - who had the support of Sufi clerics. ${ }^{203}$ Presenting themselves as the heirs of 'traditional' families that had played a role in pre-colonial Kajoor was, in fact, a line of argumentation that automatically excluded ethnic arguments. Many such families claimed, in terms of origin, ancestors in different regions of Senegambia: it would have been problematic to associate them with one ethnocultural heritage. This is obvious from the example of Sakhevar Diop, canton chief of Tiilmakka, a region neighbouring Kebemer. He claimed the heritage of the families of the Diop and the Sall, and declared that they were two 'mixed' families, with historical links to both leading Wolof-speaking families and to the Fuuta Tooro nobility. Moreover, Sakhevar Diop had long established a network of patronage in his canton, a network which was fully non-ethnic. This form of organisation of patronage was typical for northern Senegal. ${ }^{204}$ The same type of patronage was exerted by Massamba Kangue Sall,

201 ANS, 11D1/960, Lalourette to Deschamps, Chefferies des Cantons du Nord de la Circonscription de Louga ( $\mathrm{n}^{\circ}$ 100), 13 Sep. 1943, 1.

202 ANS, 11D1/1393, Administrator of Subdivision of Kebemer, Notes sur la Manière de Servir de Sangoné Sall chef de Quatrième classe (without number), without date [1958/59], 1.

203 ANS, 11Di/1393, Armand, Administrator of Subdivision of Kebemer, Notes sur la Manière de Servir de Sangoné Sall chef de Quatrième classe (without number), 3 Mars 1958, 1; ANs, 11D1/1393, Piganiol, Administrator of Subdivision of Kebemer, Notes sur la Manière de Servir de Sangoné Sall chef de $4^{\circ}$ classe (without number), 23 April 1957, 1-2; ANS, 11D1/1393, Administrator of Subdivision of Kebemer, M. Sangoné Sall - Chef de Canton de N'Doyène Daga Ne Dour (without number), without date. The situation remained so even after the disappearance of the Sall family from local power. In the 1960s, the Kebe lineage defended its authority on the same grounds, losing it thereafter to the 'Fall clan', see Cottingham, Clement, 'Political Consolidation and Centre-Local Relations in Senegal', Canadian Journal of African Studies 4(1), 1970, 101-20, 106.

204 ANS, 11D1/1393, Auchapt, Administrator of Subdivision of Kebemer, Notes sur la Manière de Servir de Diop Sakhévar chef de hors classe (without number), 3o March 1958; ANs, 11D1/1393, Armand, Notes sur la Manière de Servir de Diop Sakhevar chef de gème classe (without number), 30 March 1958; ANs, 11D1/1393, Piganiol, Administrator of Subdivision of Kebemer, Notes sur la Manière de Servir de Sakhaver Diop chef de Canton stagiaire (without number), 27 Feb. 1957, 1. 
another representative of the Sall family who successfully ruled over Wolofspeaking peasants and Fulfulde-speaking herdsmen. While being identified by the French as 'Wolof', his dynasty, the Sall, claimed to be a 'Tukulor warrior family' linked to the former ruling family of Fuuta Tooro. ${ }^{205}$ Meïssa M'Baye Sall, the canton chief of M'Baouar, argued effectively with the same mixture of group affiliations - and he enjoyed a very similar success in his canton. ${ }^{206}$

In northern Senegal, this authority, based on pre-colonial state experience, was even more stable, although it could be threatened by the intensification of conflicts between Pulaar-speaking cattle-breeders and Wolophone peasants. From the 1940s, Fulbe leaders became more organised and increasingly aggressive. Fulbe headmen wished, as French administrators interpreted it, to 'escape Wolof tyranny and defend their land against Murid control'. As we have seen with regard to the battle of Vereck, the propaganda of Fulfulde-speaking leaders was indeed directed both against the activities of an oppressive 'other', 'the Wolof', in terms of an ethnic group, and against the attempts at religious monopoly by the Murids. ${ }^{207}$ Under these circumstances, even feared chiefs such as Sangoné Sall had considerable difficulties and often failed to ensure the loyalty of the Fulbe inhabitants of the area. In particular, the marginal zones of such cantons became unruly places until the independence of the colony. ${ }^{208}$ Here - but only here - sporadic tensions relying on an ethnocultural basis could be perpetuated into long-lasting struggles.

The evolution of the 1940s and 1950s, with a renewed popularity of ethnic arguments peaking in some parts of the Petite-Côte, but which was normally not very lasting in the coastal zones and their hinterland, is reflected in the discussion about 'tradition'. Unfortunately, we face a lack of transcribed material, as the oral 'traditions' of Senegalese gëwel (griot) culture were only rarely written

205 ANS, 11D1/1393, Administrator of Subdivision of Kebemer, Notes sur la Manière de Servir de Sall Massamba Kangue chef de hors classe (without number), 30 March 1958, 1; ANS, 11D1/1393, Auchapt, Administrator of Subdivision of Kebemer, Notes sur la Manière de Servir de Sall Massamba Kangué chef de Canton Hors classe (without number), 20 June 1959.

206 ANS, 11D1/1393, Auchapt, Notes sur la Manière de Servir de Sall Më̈ssa M'Baye chef de la hors classe (without number), 20 June 1959; ANS, 11D1/1393, Administrator of Subdivision of Kebemer, Notes sur la Manière de Servir de Sall Meïssa M'Baye chef de la hors classe (without number), without date [1958], 1; ANS, 11D1/1393, Piganiol, Administrator of Subdivision of Kebemer, Notes sur la Manière de Servir de Sall Meïssa M'Baye chef de Horsclasse (without number), 27 Feb. 1958, 1.

207 ANS, 11D1/973, Plan de Protection [du Territoire du Sénégal]: Chapitre II: Hypothèses (without number), without date [1957], 11.

208 ANS, 11D1/1393, Administrator of Subdivision of Kebemer, Notes sur la Manière de Servir de Sangoné Sall chef de Quatrième classe (without number), 3 Mars 1958, 1. 
down. The French only slowly started with such collections in the interwar period and after the Second World War, and they never created any larger corpus. Nevertheless, some 'traditions' were put in writing during the period. The Library of Saint-Louis in 1941 registered a 'traditional account' by Amadu Wade, a member of the former ruling dynasty of Waalo, which can be regarded as 'authorised'. Wade's account is significant as it provides an 'official' founding myth of Waalo. This founding myth presents perceptions of different groups that are highly relevant to our discussion. ${ }^{209}$

The presentation of the distinct groups is enlightening. The narrator of the account identifies the 'Peulhs' and the 'Sérères' as part of a refugee group coming from the north, and being involved in the foundation of the new states in the region, like Fuuta Tooro and Waalo. The subjects of the Buur Siin, who comes from the south to swear allegiance to the dynasty of Waalo, are explicitly characterised as Sereer. ${ }^{210}$ In reality, the emergence of the Wolof language, which, according to the account, had not existed as an 'indigenous language' before, is described as result of the effort of the inhabitants of Siin and Waalo to create a state language for the Grand Ouolof, a large territorial structure that can be identified with the mythical Kingdom of Jolof. Here, the legendary N'Diadiane N'Diaye (or Njajaan Njay), first Brak of Waalo, becomes the first king. ${ }^{211}$

The occasionally confusing account shows clearly, in accordance with my interpretation of 'Wolof identification' in the pre-colonial and colonial periods, a conception of 'being Wolof' that is entirely different from other group labels in the region. In the Wade account, the quality of 'Wolof-ness' is deliberately connected to state structures. It is also true that other family traditions like that of the Diass, asserting themselves as centuries-long claimants to monarchic power in Waalo, present things differently. ${ }^{212}$ Their version is closer to the influential report given to the French at the end of the nineteenth century by Yoro Diaw. The Chief Legbi Bigué N'Diaye, in his account of the foundation of Waalo, claims that 'Wolofs and Peuls arrived together in the Jolof'. This version thus distinguishes from the outset the two labels as different ethnic groups and distinct units. However, it has to be said that the Diass legend was

209 Bomba, Victoria, 'Genealogies of the Waalo matrilineages of Dioss, Logre and Tédiègue: versions of Amadou Wade and Yoro Dyao', Bulletin de l'IFAN, Série B sciences humaines 41(2), 1979, 221-47.

210 ANs, 10D4/33, Le Oualo, account given by Amadou Wadde ('de Dagana'), translated into French by Cissé Amadou Bassirou, librarian in Saint-Louis (without number), May 1941, 1-2.

211 ANs, 10D4/33, Le Oualo...(without number), May 1941, 6.

212 The most recent discussion of the founding myths takes the importance of 'Wolof' group sentiment as a given, see Sall, Samba Lampsar, Ndiadiane Ndiaye et les origines de l'empire Wolof (Paris: Harmattan, 2011). 
little more than a very brief account in comparison to the more substantial and influential founding legend given by Wade. ${ }^{213}$ Finally, Boucar Boydo's 'founding legend of the Fulbe' was also very different from the account of 'the Wolof': the Fulbe myth refers from the outset to the 'Peul' as an ethnic community. The Fulfulde-speakers felt marginalised in the confrontation with Wolophone peasants and rarely took part in the material improvement from which the colony profited between 1945 and 196o. During their mobilisation attempts, leaders emphasised strongly their Fulbe identification. ${ }^{214}$

As a whole, even with the politicisation of rural regions in the colony of Senegal after 1945, the component of ethnic conflict still remains small. Only occasionally and for some communities, does the researcher find a local awareness of the opportunities given by ethnic arguments, particularly in order to oust 'strangers' and to obtain their positions or land. However, as a sentiment, it was of little appeal, unstable, and mingled with feelings of allegiance to other sub-groups. In this situation, most of the Wolophone chiefs in the northern, but also in the southern coastal hinterland of Senegal, were easily able to recover their reputation after attacks. To stabilise their position against local unrest, potential riots, and the critique from the colonial administration, they needed to adapt to a degree in terms of political style. Such Wolophone chiefs kept a low profile and abandoned some of the abuses that had characterised former methods of local rule, or those of their predecessors.

In the regions between the Senegal River and the Siin-Saluum area, the category of being 'Wolof' was rarely voiced in any conflicts. It was atypical as a category used to organise group mobilisation. While Wolophone populations appear to have been aware of the possibility of referring to 'Wolof identification', they rarely did. State structures as point of reference, eventually bolstered through a centuries-long historical experience, were far more important in local perceptions. Where under colonial rule the continuities were evident, as in the cercle of Louga or in parts of the cercle of Thiès, this legacy of selfcategorisation was easier still to maintain. Here, important families relied explicitly on accounts of their past glory, which linked them to dynasties of provincial influence, as in Kajoor, Waalo, or, to a lesser extent, Bawol. Further southwards, the existing state structures had been removed, and while some of the new, Wolophone chiefs had links to the dynastic families of Siin or Saluum, most did not boast such important relatives. Nonetheless, after the

213 ANs, 10D4/33, Chronique des Diass (communiqué par le Chef Legsi-Bigué N'Diaye du YengYeng Géboul) (without number), without date.

214 ANs, 10D4/33, Ka Boucar Boydo, Congrès de l'Union des Peuls: Rapport d'ensemble par M. Boucar Bayde (without number), 9 Oct. 1957, 1, 5. 
disappearance of the pre-colonial states, the colonial administration had immediately filled the vacuum in provincial organisation by imposing its own order. Most of the Sereer-speakers in the region had bowed, after the French conquest, to continuities from the former order, oppressive sometimes, yet mostly 'reliable'. The democratisation of the 1940 did not rapidly change this basic assumption: although Sereer-speakers occasionally challenged the ruling authorities through ethnic mobilisation, internal fissures and ambivalences within the group ultimately made this challenge very ineffective. Remarkably, the word 'Wolof', and the 'Wolof identity' of one side of an eventual conflict, continued to be very rarely mentioned. Finally, the violent experiences of the Fulbe herdsmen in their relations with Wolophone populations posed the only real challenge within a situation in which the ancient state structure became a considerable antidote to tensions expressed through ethnic difference.

\section{Joal-Fadiouth: Centre of Multiple Identifications and Place of Strategic Employment of Allegiances (1840-196o)}

The city of Joal-Fadiouth on the Petite Côte represents an outstanding case study for illustrating in still more detail the processes related above. The originally separate communities of Joal and Fadiouth, which then became fused into a single urban centre under colonial rule, were an early zone of contact between a number of Wolophone settlers of which at least a part had directly immigrated from the north, and other ethnic groups, among which the Sereerspeakers represented the large majority. At the same time, in the nineteenth century, the inhabitants of Joal had to cope with the influence of different precolonial state structures. Siin was obviously the most engaged of the entities in the region, and Joal remained during large parts of the first half of the century in a tributary relationship to the Buur Siin. However, the rulers of Saluum and Bawol were also occasionally active in the region, mostly during military campaigns. The immediate surroundings of Joal are, consequently, a highly interesting case to investigate the logic of solidarities.

As a community, the inhabitants of Joal defined themselves as 'mixed'. This condition concerned ethnocultural terms, but, later, also a reputation as being a 'neutral zone' between Muslims and Christians. The informants of the Spiritan missionaries explained at a very early stage to the Order of the Holy Ghost Fathers that they were 'half Sereer and half Wolof'. ${ }^{215}$ Leaders of

215 AGCSE, 3 I 1.5a5, Gallais, Complément des notes sur la mission de Joal. Royaume de Sine Sérères - Wolofs - Joal. (without number), without date [ca. 1850], 16. 
local political life in Joal often boasted that they were able to employ the two languages; bilingualism was a fact elsewhere on the Petite Côte, but in the town it was much referred to. As an additional element in complex group relations, a good part of the local elite referred in parallel to their 'Portuguese' identity, as early missionaries had indeed been Portuguese, and Eurafrican populations of Portuguese descent were a longstanding factor on the coast.

At first glance, the members of the community of Joal thus had a group identification marked through various factors. More remarkably, however, the inhabitants of the town distanced themselves in their conversation with French representatives from the use of both local languages, Wolof and Sereer - although speaking both languages in everyday life. The judgment on the Sereer language was damning: the residents of Joal held that Sereer was 'primitive'. Nonetheless, the leaders of the community argued that Wolof could not be employed either in any important local context, as the 'Sereer' spirits living in the interior of the holy Baobab trees of the region would regard the employment of the 'foreign' idiom as a sacrilege; they would avenge themselves and slay the Wolof-speakers on the spot if this language became too prominent! 216

This overall context leads to a very peculiar picture. Joal was a mixed society in many respects, but one in which the regional prejudices of both of the two dominant local language groups were found, and were used against the world outside of the town. In this context, it is also apparent that a consciousness of particular ideas referring to different ethnic groups was clearly existent, if mostly combined with the criterion of language. However, this was not really decisive during the second half of the nineteenth century: for the inhabitants of Joal, the designation of themselves and of others as 'Wolof' or 'Sereer' was part of a larger repertoire, which was still more flexible than in other communities on the Petite Côte.

Indeed, the populations of Joal had enlarged this repertoire by adding other historical components, such as their 'Portugueseness' and their relationship toward the pre-colonial state of Siin. As concerns the latter, the leaders of the community held that the rulers of the most powerful political entity in the area represented the central point of reference. The claim of 'being Portuguese' expressed the demand to be free from any legitimate control by the pre-colonial state of Siin. On religious terms, the elite of the town was, in the early 1870 ,

216 AgCSE, 3 I 1.5a5, Gallais, Quelques notes sur l'origine de Joal, sur les Wolofs et les Cérers, extraites des lettres datées de Joal (without number), without date [ca. 1850], 2-4. 
fiercely opposed to the attempts of the Muslim section of the Wolof-speakers in the city to erect a mosque. ${ }^{217}$

The elite of Joal actively engaged in securing its effective independence from Siin during the 1860 s and the 1870 , and also attempted to obtain guarantees of continuous French support against other claims coming from Bawol and Saluum. However, the link to the authorities of Siin remained present in the memories of the local leaders of the Joal community. The inhabitants of the town behaved, very visibly, as former subjects of the Buur Siin that had not forgotten their ancient relationship. This behaviour of local leaders was evident during the visits of Koumba Ndoffène Fa Mak Diouf in their particularly reverential style. During the tragic events of 1871 , when the Buur Siin was murdered during his visit to the town, a possible outbreak of war between the army of Siin and the soldiers of Joal was avoided through the numerous relations that existed between the town and the royal troops. Those were easily sufficient to guarantee that even in a case as grave as the assassination of the Buur, the warriors from Siin spared the city (including the sparsely manned French post) from destruction. ${ }^{218}$

Between 1900 and 1945, the relationship between the different ethnic groups within the urban community had no place in local discussion. Sereer-speakers were theoretically in the majority, but the local hierarchy was led by Fulfuldespeaking and Wolophone notables. Both the ethnic and the religious dimension remained in the background for several decades: the centre of Joal-Fadiouth was a place where different linguistic communities coexisted, and where the Murid Muslims enjoyed a status similar to that of the Catholic community.

This picture changed in the 1940s. With the impact of post-war reform, Joal lived through a period of important political troubles in which the question of belonging to communities was newly and consistently posed. For the decades of relative tranquillity, Meïssa Fall, the Fulfulde-speaking chief of the canton of Joal-Gohé (whose family came from Fuuta Tooro) including the town, had had a rather uncomplicated task in governing the inhabitants of the region. He was undoubtedly known to rule with a relatively firm hand, but - like Ely Manel N'Diaye in Diaganiao and Socé Fall in M'Bayard-Nianing - he had become popular in the region. He was one of those 'traditional rulers' who had rapidly learned to play the game, even before the first movement against abuses committed by chiefs that flared up in the 1940s: Fall respected well enough the political prerogatives of local headmen, he pleased the wishes of the highly

217 AGCSE, 3 I 1.11b3, Lamoise, French missionary in Joal, to Schwindenhammer, Provincial Superior of the Spiritan Mission (without number), 30 June 1871, 3.

218 AGCSE, 3 I 1.11b3, Lamoise to Schwindenhammer (without number), 12 Dec. 1871, 2-4. 
corporatist Sereer-speaking fishermen, and he did his best to protect the local artisans from outside competition and to improve conditions of marketing and sales of local products. The chief had visibly 'succeeded in Sereer territory'.219 As a local partner, Meïssa Fall was also held in high esteem by the French administrators.

An attack came, rather unexpectedly, in May 1946. The assault against Meïssa Fall's chieftaincy was in part an affair of the territorial politics discussed above; it reflected the shifts in the regional balance of power under the impact of the reforms instituted in 1945. The central figure linking the local affairs concerning Joal and Fadiouth to the new territorial assembly of Senegal in SaintLouis, was, again, Jacques d'Erneville, a sort of personal envoy of the recently elected deputy of Senegal, Léopold Sédar Senghor. The latter was in 1946 still in the ranks of the SFIO from which his followers would only split in late 1947. Senghor's envoy visited, in the first half of 1946, the different settlements in the area between M'Bour and the Siin-Saluum River Delta. After passing through Joal and meeting with members of the nascent party living there, he wrote a long letter to his patron about the particular case of Meïssa Fall. ${ }^{220}$ D'Erneville remarked that Fall, who was hostile to SFIO activities during this period, had absolutely no right to stay in the post he held, as he was a 'foreigner', not an originaire of the region. The party was to return him to live in a canton of his own region of origin ('dans un canton de chez lui'), insisted d'Erneville. ${ }^{221}$

The French cercle commander, informed about these proceedings, was less certain about the facts presented by the Senegalese deputy and his auxiliary. He believed that both Senghor and d'Erneville were manipulating the facts in the interest of their party. Undoubtedly, many of the powerful chiefs in the coastal cantons were still not used to making alliances with the new political class, namely with the leaders of the SFIO, later with the BDs. Therefore, Meïssa Fall, like many of his colleagues in rank ruling in the region, was considered an enemy by the party militants. They held that Fall retained a disquieting power base to influence the voting decisions of his 'subjects', and SFio politicians used all means to discredit the legitimacy of such a potentially hostile 'traditional ruler'. With Fall, this seemed to be easy: his detractors

219 ANS, 11D1/1303, Rey, Governor of Senegal, to District Commissioner of Thiès, Au Sujet Chefferie canton Diaganiao ( $\mathrm{n}^{\circ}$ 1112/APA), 30 June 1941, 2.

220 On the local powers of deputies between 1944 and 1957, see ANS, 10D1/36, Lami, District Commissioner of Thiès, to Bailly, Governor of Senegal, Plai $[n]$ te de Mr. le Député Senghor (n $28 /$ AGO), 24 Jan. 1951.

221 ANS, $11 \mathrm{D} / 1382$, d'Erneville, envoy of Léopold Sédar Senghor, to Senghor (without number), 7 May 1946. 
brought forward claims that cast doubt on the chief's rootedness in the canton. ${ }^{222}$

The representatives of the colonial power attempted to judge the 'ethnic legitimacy' of local protests. Hence, in 1947, Larrue, the administrator of the subdivision of M'Bour, carried out additional research on the Sereer-speakers in the Joal area. He felt considerably perplexed by the results. According to his informants, the Sereer-speakers of the region were a mosaic of different subgroups: the 'Sereer Siin' and the 'Sereer Dieguène' of Aga-Gohé canton were, if each one was at all to be taken as a group in its own right, in cultural and linguistic terms completely different from the 'Sereer Fadiouth' of the area of the town. Larrue held that the Socé family of Joal, with its close links to the Sereer headmen, had exerted a real 'tyranny' over the two former groups; only the French takeover of the town in $\mathbf{1 8 6 4}$ had 'liberated those oppressed people'. Larrue's information corroborated the existence of new pan-Sereer tendencies, but his report insinuated that such tendencies were only the result of goals of political mobilisation for momentary gain. ${ }^{223}$

The police reports from Joal, transmitting details from political meetings in the region, give us an extensive picture of propaganda after 1945: most of the campaign was in fact directed against the paramount chief, and thus had to be anti-Tukulor. Some anti-Wolof and pan-Sereer agitation also flared up in JoalFadiouth. This peaked at moments of electoral campaign activity by d'Erneville and Senghor in 1946. However, we find little inclination on the part of regional SFIo leaders to continue their engagement on an ethnic ticket after the electoral support of the canton had been won. ${ }^{224}$

The politically-motivated campaign against the paramount chief, led with ethnic arguments, did not fail to have an impact on the administrative realities in the region. While colonial officials tended to be sceptical about the activities of Senegalese party politicians, they did not remain entirely unaffected by the ethnic claims. Cazenave, the French district commissioner in Thiès, in the end employed the same ethnocultural terms for the description of the political situation in the area of Joal-Fadiouth. This had repercussions on the discussion

222 See, among others, the cases of the struggle between SFIO and BDS for the chieftaincies in Kaolack in ANS, $11 \mathrm{D1} / 1148$, Security Service of Kaolack, Renseignements: Nomination de Chef de quartier ( ${ }^{\circ} 405 / \mathrm{c} / \mathrm{SU}$.), 11 June 1949, and for Tambacounda in ANS, 11D1/1059, Sada Maka Sy to District Commissioner of Tambacounda and Senghor (without number), 20 Sep. 1956.

223 ANS, 11D1/1320, Larrue, Administrator of Subdivision of M'Bour, to Cazenave, District Commissioner of Thiès, Projet création Subdivision Joal ( $\mathrm{n}^{\circ}$ 199/C), 31 Oct. 1947, 3.

224 ANS, $11 \mathrm{D} 1 / 1320$, Minot, commander of the Gendarmerie Post of Joal, to Larrue ( $\left.\mathrm{n}^{\circ} 34 / 4\right)$, 16 Oct. $1947,1$. 
of administrative reforms, which were conceived in ethnic terms. The outcome of the plans for ethnic reorganisation was, however, surprising.

Based on the information about ethnic difference he had so constantly received, Cazenave now proposed a neat separation of the towns of Joal and of Fadiouth on an ethnic basis. He argued that the fishermen of Fadiouth, 'all Sereer', were a 'clan à part'. They were to be treated as such, and to be administered separately. However, the inhabitants of Joal, while being seen as immigrants, mostly spoke both Sereer and Wolof, and they had manifold contacts, including through family links, with the Sereer-speakers of Fadiouth. Thus it proved difficult to truly establish them as a homogeneous group. When Cazenave attempted to enforce the administrative separation, it became evident that the locals of Fadiouth did not want this particular reform at all. ${ }^{225}$

Cazenave then tried to organise a complete reorganisation of the canton on ethnically-defined group terms. However, the headmen of both Joal and of Fadiouth came to protest vehemently. They explained to the French official that they entirely refused the partition of the town area, a measure against which they would violently mobilise if necessary! Sereer-speaking fishermen sided with Wolophone artisans in this wave of protests. Finally, the French administrators gave way and silently buried their project. ${ }^{226}$ The resulting solidarities coming from a common experience of the past went beyond ethnicity - and beyond simple community solidarity, as Joal and Fadiouth had long been distinct communities, and there was no automatic siding between their inhabitants.

Nevertheless, Meïssa Fall did not in the long run escape the political troubles. Local agitation on the grounds that Fall was a 'Tukulor stranger' continued in the background: the local organisers of party campaigning in the 1950s, now representing the BDS, clearly hoped for the spoils after Fall's downfall; and for this reason, the ethnic card would in his case be successfully maintained. Fall fought back in a determined manner; only in the post-colonial state was his presence no longer feasible, and the ever-increasing pressure from a section of the local population finally led to his removal. ${ }^{227}$ However, even in a circumscribed local arena of the Senegalese coast, it becomes obvious that ethnic solidarities were often not the most important element of group identity. Notably, common political experiences were far more essential.

225 ANS, 11D/1382, Cazenave, District Commissioner of Thiès, to Durand, Governor of Senegal ( $\left.{ }^{\circ} 432 / A G / C C\right), 23$ July 1946.

226 ANs, $11 \mathrm{D} / 1382$, Larrue, Administrator of Subdivision of M’Bour, to Cazenave $\left(\mathrm{n}^{\circ} 214 / \mathrm{C}\right)$, 26 July 1946.

227 ANs, $11 \mathrm{D} / 1382$, Sow Abdul Karim, 'Chefferies et Combines' (without number), without date. 


\section{Into the Independent State: 'Wolofisation' and the Integration of 'Tribal' Thinking in Northern Senegal's Post-Colonial Political Language}

After the independence of Senegal in 1960, the existence of ethnic groups as primary poles of allegiance became an accepted fact among politicians. The leaders of the Union Progressiste Sénégalaise (UPS), the unity party that was the successor movement of the BDS and BPS, in a fusion with the SFIO and some splinter parties, claimed to represent the entire Senegalese population. This claim appeared to make an engagement with ethnic issues highly necessary. At least at the local level, UPS politicians decided that there was a strong demand for ethnic claims, which led to a new double language. Following the nationalist logic of most post-colonial African states, Senegalese statesmen and diplomats normally avoided mentioning the impact of the different ethnic groups in their country, or, at most, they drew a picture of particular 'tribal harmony'. In this, the Senegalese political elite employed a discourse that, like in other West African countries, condemned the nefarious effects of 'tribalism'. The UPS leaders gave this discourse a particular attention, presenting Senegal as a very special society where ethnicity was balanced by the friendly relations of groups.

However, on the local level, the references were entirely different, at least in the first years after decolonisation, including on the Petite Côte and its hinterland. The Minister of the Interior, Valdiodio N'Diaye, while visiting the town centre of Fatick in the former region of Siin pointed insistently to the role which the Sereer populations of Senegal had played in the process which had led to national independence. 228 Instead of a 'regionalist' he played an 'ethnic' card. Prime Minister Mamadou Dia was even more explicit regarding ethnicity during a speech delivered in the same region: he presented the ancient ethnic conflicts as no longer existent in Senegal, but the ethnocultural groups continued to exist and to play an important role as points of reference: 'as the Tukulor that I am, [I was glad] to be adopted by the Sereer of Siin.'.229

\footnotetext{
228 MAE, DAM, Sénégal, 3117, Valdiodio N'Diaye, Minister of the Interior of Senegal, Discours prononcé à Fatick le 29 Mars 1962 par Me Valdiodio N'Diaye à la Cérémonie d'Inauguration du Monument de l'Indépendance (without number), without date, 4; MAE, DAM, Sénégal, 3117, Hettier de Boislambert, French Ambassador in Senegal, Compte-rendu hebdomadaire $N^{\circ} 13\left(\mathrm{n}^{\circ} 435 . \mathrm{CP}\right), 2$ May $1962,3^{-4}$.

229 MAE, DAM, Sénégal, 3117, Hettier de Boislambert, Compte-rendu hebdomadaire $N^{\circ} 33$ $\left(\mathrm{n}^{\circ} 1.044 / \mathrm{CP}\right), 20$ Aug. 1962, 1.
} 
Some groups, whose leaders felt excluded from the state structures, maintained more aggressive ethnic formulations. This was the case for the members of the Union des Peuls du Sénégal et de la Mauritanie, a movement founded in the wake of political reform and autonomy in the territory, and rapidly banned by the then independent government in 1960. The most distinguished leader of this association, Boucar Boydo, bitterly complained in 1957 that 'in our ministries, our ministers speak Wolof and do not master the Peul dialect.' ${ }^{230}$ Boydo's position was, and remained, a minority view after independence. For a semidemocratic government, it was easy, in the 196os, to remove institutionalised 'tribal' associations like the Union. Fulbe mobilisation against Wolof peasants remained a minor source of tensions in the post-colonial state. ${ }^{231}$

In the end, the transformation from colonial rule to the post-colonial period seems to have allowed for a continuation of loyalty to state structures that characterised at least northern coastal Senegal. The role of the Cap-Vert Peninsula, and, in particular, of the city of Dakar, has contributed to this continuity. Community life under urban conditions has not led to a stronger segregation of regional and self-declared ethnic groups, as in Senegal the political structure dominated over ethnic sentiment. The urban setting of Dakar allowed for rapid linguistic assimilation, including all the phenomena of multilingual individual life that I discussed in the introduction to this chapter. As long as there was no regional feeling of exclusion from the state structures, even the argument of 'Wolofisation' was unlikely to lead to counter-mobilisation along ethnic lines. The exception to this rule is Casamance, where conditions had been extremely different in the period of the French conquest, and were exacerbated by a relatively recent immigration of Wolophone settlers. The Gambia is even more interesting as a comparative example, with a similarly fragile state structure but an older Wolof presence.

\section{A Glance into the Gambia: Wolof Identification at the Margins of the 'Wolof State' of Senegal}

The communities of the territory of the British colony of the Gambia had been in longstanding contact with pre-colonial states ruled by Wolophone dynasties,

230 ANs, $10 \mathrm{D}_{4} / 33$, Ka Boucar Boydo, Congrès de l'Union des Peuls (without number), 9 Oct. 1957,5 .

231 See ANS, Vice-Présidence et Présidence du Conseil de Gouvernement du Sénégal (VPP), 000203, Abdoulaye Fall N'Dar, Kalif of the 'Baye Fall' Murids, to Mamadou Dia (without number), 29 May 1959. 
and had areas administered by Wolophone paramount chiefs. At the same time, they also lived under the influence of the British style of colonial organisation. ${ }^{232}$ In 1876 , the troops of Saluum attacked Badibu, a local political entity, in retaliation for the support that Badibu's Jihad ruler, Mahmud N'Dare Bâ, had given to Mâ Bâ, the cleric fighting Saluum's pre-colonial dynasty. ${ }^{233}$ Moreover, the Wolophone Buur Saluum, Sadiuka Mbodj, held several dignitaries in the central and upper river regions in a tributary relationship, which would only lessen with the gradual loss of power of Saluum in the 1870 s and 1880 s. $^{234}$ The ruler of Badibu had his family origins in Kajoor: like his brother, Ama Bâ, he had established himself in the river area. His enmity with Sadiuka Mbodj destabilised the whole region to the north of the river. Further eastwards, there was some Wolophone immigration into the Upper Niani, apparently from the Fuuta Tooro; these settlers were quite aggressive and violent towards Wolophone commercial agents working for the Compagnie Française de l'Afrique Occidentale (CFAO). French troops, in retaliation for incidents with members of this group, attacked the town of Kutchar in $1889 .{ }^{235}$ The polarisation of identifications in the Gambia River region went hand in hand with Jihads. ${ }^{236}$ War had started on the northern bank in the 1840 s and pitted 'Soninke' and 'Marabouts', according to local terminology, against each other. The Almami (religious-spiritual and political leader) of Badibu was a champion of enforced conversion to Islam. ${ }^{237}$ The discourses of group leaders during the conflict in Badibu and other small political units of the area were completely dominated by religious questions. Mahmud N'Dare Bâ had an ethnically mixed following,

232 Diouf, Sénégal, 34.

233 tNA, Pro, CO/879/13, African Confidential Print No. 152, Cooper, British Acting Administrator of the Gambia, to Kortright, Governor of Sierra Leone (without number, Enclosure 1. in No. 1), 29 June 1876, 2.

234 Quinn, Charlotte A., Mandingo kingdoms of the Senegambia: Traditionalism, Islam, and European expansion (Evanston: Northwestern University Press, 1972), 36.

235 TNA, PRo, CO/879/28, African (West) Confidential Print No. 36o, Manager of McCarthy's Island to Acting Administrator ( $\mathrm{n}^{\circ}$ 103, as Enclosure in No. 57.), 25 July 1889.

236 British observers of the 1840 - following Mungo Park's example - already attempted to distinguish Gambian Mandinka, Wolof, and Fulbe through their physical features, compare Grey, Earl, 'Abridged Account of an Expedition of about 200 Miles up the Gambia, by Governor Ingram', Journal of the Royal Geographical Society of London 17, 1847, 150-5, 153. In the 189os, the British were convinced they had found five different 'races' (Wolof, Mandinka, Jola, Sarakole, Fulbe) in the Gambian territory, see Denton, George C., 'TwentyThree Years in Lagos and the Gambia', Journal of the Royal African Society 11(42), January 1912, 129-40, 133-4.

237 TNA, PRo, CO/879/11, African Confidential Print No. 124, Brown to Carnavon (without number, $\mathrm{n}^{\circ} 12$ in series), 8 Feb. $1877,2$. 
whose members were eventually identifiable as 'Mandinka,' 'Wolof', 'Fulbe', and others, but united through the Islamic religion. ${ }^{238}$ Amongst the Mandinkaspeakers, questions of status also outweighed those of ethnic affiliation: slavery remained a fact until at least the end of the First World War, as Mandinka slaves, while being integrated into the Mandinka-speaking leading families, were considered as socially inferior. Therefore, settlements of rebellious or refugee slaves were the primary target during military campaigns. ${ }^{239}$

In other parts of the Gambia River region, local populations at the margins of the more reliable state structures had more frequent recourse to ethnic identifications. Also, with the extension of their small river colony in the second half of the nineteenth century, British officials attempted to sustain 'authentic structures' and to find the appropriate 'tribes'. Colonial ideology and practices of colonial rule thereby created fundamental differences in the behaviour of Gambia's Wolof-speakers. ${ }^{240}$

In the late colonial period, the Gambia was characterised by the slow takeover of an 'educated elite' around the United Party (UP), which represented the commercial interests of Bathurst and was regarded by the British as the natural candidate to lead the post-colonial country after independence. ${ }^{241}$ However, on the occasion of the 1962 territorial elections, the People's Progressive Party (PPP) took power in the then autonomous territory, to the general surprise of experienced commentators in the region. ${ }^{242}$ This development was frequently interpreted as the result of a 'green uprising' in which 'the Mandinka' as a rural majority defeated the aspirations of an elite of 'strangers': the urban Wolof-speakers concentrated

238 TNA, PRo, CO/879/13, African Confidential Print No. 152, Brown to Carnavon (without number), 19 Sep. $1877,1$.

239 Bellagamba, Alice, 'Slavery and Emancipation in the Colonial Archives: British Officials, Slave-Owners, and Slaves in the Protectorate of the Gambia (1890-1936)', Canadian Journal of African Studies 39(1), 2005, 5-41, 13, 25; Webb, Patrick, 'Guests of the Crown: Convicts and Liberated Slaves on McCarthy Island, the Gambia', Geographical Journal 16o(2), 1994, 136-42, 140 .

240 On the 'Wolof' as a group in the Gambia, see Hughes, Arnold, and David Perfect, A Political History of the Gambia, 1816-1994 (Rochester/NY: University of Rochester Press, 2006), 16-7. The navétanat in Senegal reappears as 'strange farming' in the Gambia, see Swindell, Ken, 'Family Farms and Migrant Labour: The Strange Farmers of the Gambia', Canadian Journal of African Studies 12(1), 1978, 3-17, 4-5, 14-6.

241 Hughes and Perfect, History, 132-3, 136-7, 144-5.

242 See MAE, DAM, Sénégal, 3117, Hettier de Boislambert, Compte-rendu hebdomadaire $N^{\circ} 23$ $\left(n^{\circ}\right.$ 722.CP), 11 June 1962, 9. On the mobilisation of Mandinka 'tradition' by the PPP, see Bellagamba, Alice, 'Entrustment and its changing political meanings in Fuladu, the Gambia (1880-1994)', Africa (London) 74(3), 2004, 383-410, 399-400, for the distribution of the vote, Hughes and Perfect, Policy, 150-1. 
in the population centre of Bathurst. ${ }^{243}$ Later, however, President David (Dawda) Jawara increasingly played the card of regional solidarity with Dakar to protect his rule, and these tactics were interpreted as 'Wolof networks'.

In the current-day Gambia, unlike in Senegal, the idea of 'ethnic harmony' is not a part of national elite ideology. 'Ethnicity' is frequently debated as a factor to explain contemporary political frictions in Gambian politics. In 1981, the government of Dawda Jawara, the eternal political leader of independent Gambia, was menaced by a coup d'état, allegedly by Jola-speaking army units rebelling against the marginalisation of their ethnic group in a Mandinkaand Wolof-dominated society. ${ }^{244}$ Jawara was saved by Senegalese troops, and this was eagerly read as an introduction of 'Wolof rule' to the detriment of other 'ethnic' groupings, in a country where a 'Mandingo party' - the PPP had dominated political life. ${ }^{245}$ The subsequent and final fall of Jawara, due to a putsch of the Gambian army under Yahya Jammeh in 1994, has since been regarded as the normalisation of the ethnic balance of power in the small country. ${ }^{246}$

These views on ethnicity need to be tempered by a more local perspective. In the Gambia's Lower Saloum District, chieftaincy conflicts and group solidarities illustrate a complex pattern. First of all, conflicts existed within the 'chiefly family'. In August 1950, the Lower Saloum District became a place of constant unrest after the return of its former seyfu ('traditional chief'), Bara Turay. ${ }^{247}$ Turay, a Wolof-speaker, had been dismissed by the British administration for abuses and had been in exile in Senegal for a couple of years. During this exile, his material possessions had repeatedly been used by 'trustees' in their own interest. His successor had been his own son, Ali Turay, who had no sympathy for his father and had confiscated his father's possessions to support his personal and dynastic position in the district. This led to a fierce conflict arising after Bara Turay's return, which brought questions of broader group

243 Hughes, Arnold, 'From Green Uprising to National Reconciliation:The People's Progressive Party in the Gambia, 1959-1973', Canadian Journal of African Studies 9(1), 1975, 61-74, 63-4.

244 Sallah, Tijan M., 'Economics and Politics in the Gambia',Journal of Modern African Studies $28(4), 1990,621-48,635^{-6}$.

245 There is no reference to the ethnic dimension of Senegalese involvement in the Gambia in the early 1980 in most studies, see Hughes, Arnold, 'The Senegambia Confederation', Contemporary Review 244(1417), 1984, 83-8.

246 Hughes, Arnold, 'Democratisation” under the military in the Gambia: 1994-200o', Commonwealth \& Comparative Politics $38(3)$, 2000, 35-52, 48; and Hughes and Perfect, History, 280-1.

247 NRSTG, PUB 13/12, Minute, 30 April 1951. 
solidarities in the Lower Saloum District onto the agenda. ${ }^{248}$ For decades, the declared objective of the British administration had been to guarantee an 'ethnically appropriate' administrative set-up for this district. However, in 1950 the administration was faced with the historical dimensions of 'Jola' and 'Wolof' identifications in the Saloum district and its vicinity.

When Bara Turay had been unseated in 1941 as paramount chief of the district because of his 'constant abuses', the local British administrators had been convinced they would not find any other candidate acceptable to all of the district's populations. They believed the population of Lower Saloum was so unstructured and diffuse that there was no collective loyalty or group of identification large enough: 'no single man, without...active canvassing [of the district administrator], could secure a majority if left to the people.'249

The decade-long vulnerability of political structures in many parts of the pre-colonial territory later becoming the Gambia, including the area of Lower Saloum, is crucial to this instability. Since 1880, the British colonial government had been engaged in establishing a stable administrative structure on the middle and upper Gambia River and installing 'authentic' chieftaincies in small districts. The British tried to interpret the situation according to ethnic classifications, which proved to be difficult.

This brings us back to the pre-colonial history of group identifications of the future colonial districts of Lower (and Upper) Saloum. In the nineteenth century, this region was evidently a complex geographical ensemble, the political realities of which the British conquerors did not quite understand. Originally, the new district had been part of Balangar, an autonomous political entity, albeit under the political influence of the Buur Saluum. Patron-client relations were more explicit between Saluum and the various smaller entities of Kaur, in the eastern part of what was to become the Lower Saloum District; the rulers of the latter had to pay tribute to the Buur. Their rulers were Wolof-speakers and they had been in power before the European conquest. ${ }^{250}$ These

248 NRSTG, PUB 13/12, Neil Weir, Senior Commissioner, Lower Saloum District Administration (without number), 9 Jan. 1945; NRSTG, PU B 13/12, Bara Turay, Extract from Enclosure 136 on M.P.HQ. 358/1942. (without number), without date; NRSTG, PUB 13/12, Brief Report on the Lower Saloum District Administration (without number), without date; NRST G, PU B 13/12, Commissioner of the North Bank Division, Lower Saloum District Administration ( $\mathrm{n}^{\circ}$ DIC.30/1(12)), without date; NRSTG, PUB 13/12, Humphrey Smith, [Confidential Note on Bara Turay] (n c/7/71), 15 Aug. 1950, 1-2.

249 NRSTG, PUB 13/12, Lian, District Commissioner of MacCarthy Island Province, to Colonial Secretary of Gambia (without number), 26 May 1942.

250 NRSTG, PUB 13/12, Lian to Colonial Secretary of the Gambia (without number), 26 May 1942, 2; NRSTG, PUB 13/12, G.A. Evans, Commissioner of MacCarthy Island Province, The 
Wolophone chiefs did not, however, show much solidarity as members of the same 'ethnic group'. If something tied them to a larger ensemble, it was indeed the loyalty to the Buur Saluum.

The British colonial administrators sought first-hand information about 'tribes', but had to admit that in 'normal' times they did not find any real 'ethnic identity'. 'Sub-groups' dominated the picture, while larger 'tribal identities' were pushed into the background. The description of the Wolophone communities of Lower Saloum emphasised the fact that 'the Jolofs of this District are anything but a pure strain' and that 'even the Turays are said to be more Tillibonko than true Jolof'. The British claimed that 'the Jolof language and dress is assumed by traders, settlers and in-laws as much as an alien in Europe changes his nationality by naturalisation'!251 Therefore, in the Gambian case, language and chosen identification depended a great deal on the professional situation of an individual, and 'Wolof-ness' rarely appeared as a stable ethnic identification.

In linguistic terms, the majority of the inhabitants of the district in 1860 appeared as Mandinka-speakers, in spite of the formal overlordship of the Wolophone Buur Saluum. Therefore, at the moment of conquest, the Jane family from Janekunda managed to make credible claims to the British that they held the 'authentic' right to the chieftaincy of the district: the principal argument they presented to the British authorities was that of being 'Mandinka' and representing the 'autochthons'. Mansajo Jane and his direct successor Amuli Jane thus became the first paramount chiefs of the newly created Lower Saloum District under British rule in the Gambia.

The information on which the British based their decision to favour the Jane family was extremely limited. British administrators did not have any accurate details about the specific elements of the pre-colonial situation, and often misunderstood the older, border-crossing solidarities. Initially unnoticed by the colonial authorities, remarkable shifts in ethnocultural loyalties were under way. From 1860 to 1940, the reported population distribution in the Lower Saloum changed in an impressive and unexpected way. Suddenly, the 'Wolof' appeared in the British documents as a clear majority of the population. ${ }^{252}$

Administrative position in the Saloum M.I.P. subsequent to the removal of the Seyfou, Lower Saloum, and some possible lines of reorganisation (without number), 31 July 1942; NRSTG, PUB 13/12, Brief Note on the History of the Chieftainships of the Saloums Compiled by Professor Daryll Freds (without number), 14 May 1945.

251 NRSTG, PUB 13/12, Lian to Colonial Secretary of the Gambia (without number), 26 May 1942.

252 Ibid. 
This major shift was to play an important role in local politics. The successive Wolophone candidates for the chieftaincy, Bara Turay and Ali Turay, profited from these changing perceptions: now they could compete for the paramount chieftaincy and base their claim on the colonial statistics of ethnicity.

It is difficult to find an explanation for such changing numbers and percentages. First of all, while there were migratory flows crossing the SenegaleseGambian border over the whole of the colonial period and beyond, this was not a principal factor, as migration was never confined to a single linguistic community or cultural group. ${ }^{253}$ Only the Fulfulde-speaking herdsmen of Lower Saloum were significantly more mobile than other local population groups, while Wolof-speakers and Mandinka-speakers show patterns similar to each other.

More importantly, there was a notion of remarkable flexibility in identifications. One particular factor was the affiliation of the large numbers of domestic slaves to the powerful, Wolof-speaking merchant families. Over the decades, the former slaves came to be counted as 'Wolof', regardless of their former group origins. This integration of slaves into kinship groups was an essential mechanism to provoke change in identifications (which is difficult to analyse in other regions, such as northern Senegal). Multilingualism also added to flexibilities.

The leading Wolophone families in the region based their influence on contacts in Senegalese territory, to which the links were easy to maintain. Wolophone populations regularly crossed the border into the region of Kaolack. ${ }^{254}$ However, ethnic solidarity was not the decisive criterion within these networks: Omar Sisi, the twice-deposed paramount chief of Upper Saloum District during the 1910 and 1920 s claimed that he was a direct heir to the ruling dynasty of Saluum, the Gëlwaar, and mobilised a 547-year old 'tradition' for his cause... ${ }^{255}$ Here again, solidarity with pre-colonial states was the more attractive option, but the British conquest had cut contenders off from this alternative source of legitimacy. If they wanted to play the game under the conditions set by the British colonial state, they had to refer to ethnocultural links, but these links could be 'adjusted' if necessary. This becomes clear from contrasting a number of local elite biographies in the region for the 1950s, including local dignitaries who were not Wolophone.

253 ANS, 10D4/4, Alsace, to Director of Native Affairs of Senegal ( $\left.{ }^{\circ} 936\right)$, 9 Aug. 1893, $1-2$.

254 TNA, PRO, CO/87/226/17, Macklin, [Report] (without number), 26 Jan. 1927, 21.

255 TNA, PRO, CO/87/226/17, E.F. Small, Editor of 'Gambia Outlook', Memorandum of the Case of Omar Sisi Paramount Chief of Upper Saloum, River Gambia. (without number), 6 July 1927,1 . 
One such personality is Biram Bâ. Over long periods of the first half of the twentieth century, Bâ was regarded as the most important representative of the Fulfulde-speakers in the district and a possible candidate for a chieftaincy in the Saluum area. However, Bâ was not at all an 'indigenous' candidate. He was, in the geographic ensemble of Senegambia, a 'northerner': his culturallinguistic origins were Tukulor, and while he was a Tijani Muslim, he was detached from the local Fulbe. Nonetheless, he managed to become the spokesman of the Fulbe herdsmen, as he was attractive as a representative of a certain standing.

In the Lower Saloum District, local dignitaries voted in chief elections. However, the latter's electoral behaviour does not fit at all with the picture of strict 'ethnic loyalties' in the Gambia. Such complexities in the behaviour of local headmen spoiled the possible career of Kebba Jane. He was a Mandinkaspeaker and candidate of the mighty Jane family that had held the paramount chieftaincy of Lower Saloum for a couple of decades after British conquest. After the dismissal of Bara Turay in 1941, he was thus one of the obvious favourites for Bara's succession. To obtain the paramount chieftaincy, he most urgently needed the votes of all the headmen of the region of Janekunda, the majority of whom were Mandinka. However, somewhat against any 'ethnic' logic, many of these dignitaries elected Katar Cissé, the Wolof-speaking chief of the neighbouring district of Upper Saloum, who had also become a candidate for Bara Turay's succession. Cissé was appreciated as an efficient ruler; this seemed to be the most important criterion for his voters. The British administrators, waiting for a result that followed 'tribal logics', were completely perplexed. While Katar Cissé in the end did not receive as many votes as Ali Turay, his relative success is remarkable: the votes of the majority of the Mandinka went to the Wolof-speaker Cissé, which destroyed the chances of the 'Mandinka candidate. ${ }^{256}$

Ethnic solidarity was more attractive in the Gambia than in the case of the French colony, due to the structures of British colonial organisation. They allowed for mobilisation via 'ethnic' arguments, if it was possible in a given situation to explain to potential followers that a rival for material or political resources (or both) was an 'outsider', someone having immigrated later with 'his people' into the region. ${ }^{257}$ However, Wolof-speakers in Lower Saloum

256 NRSTG, PU 13/12, Saloum District: 1st Ballot taken on 8:2:45 to choose a new Head Chief. (without number), without date; NRSTG PUB 13/12, Weir, Lower Saloum District Administration: Four Observations in your letter No. DIC 30/I/(12) of May 11 th 1945 (without number), 12 June 1945.

257 Bellagamba, 'Entrustment', 385 . 
District did not have enough motivation to follow such 'ethnic' arguments. Wolophone merchants already controlled the majority of local resources as related to trade and were at the core of a network; several of the most powerful individuals in the district had originated from families who had their former regions of origin further northwards, but were now well entrenched.

Regarding this background of migration, the Jane, members of the influential family of 'Mandinka chiefs' in the region, had an easy task in labelling the Wolof-speaking merchants as 'strangers'. Kebba Jane tried hard to convince the British district commissioner that the 'Wolof' knew nothing of local customs, and had pre-colonial knowledge 'in matters of trade and customs but not in the court. ${ }^{258}$ However, even with this emphasis on cultural difference and autochthony, the Jane were not able to win the majority of Mandinka-speakers in the district for their claim. The victory of Ali Turay was possible through an interethnic alliance. ${ }^{259}$

In such conflicts, the crossing of ethnic boundaries was simple in the Gambia: when it was useful for the creation of alliances, the involved groups did not show any hesitation. After 1962, the Wolof-speakers in Upper and Lower Saloum, who had before been unwavering adherents of the urban, Wolophone Bathurst elite dominating the United Party, switched sides to the PPP. The chiefs and local dignitaries hoped that this change of side would allow them to obtain the same benefits concerning national investment that had been promised by the autonomous government of Jawara to the Mandinkaspeaking PPP followers among the 'traditional rulers' in the neighbourhood. ${ }^{260}$ However, even in the post-colonial period, alliances in the local environment could be forged on ethnic terms whenever this was regarded as useful. Thus during the 1975 election of a new seyfu of Lower Saloum, the Wolof-speakers of Ballanghar attempted again to play the ethnic card to prevent the victory of a candidate of the Mandinka-speaking dynasty. On this occasion, the Fulbe of the district nominated their own 'ethnic' candidate. ${ }^{261}$

The case of the Gambia shows that different systems of indirect rule created distinct conditions for ethnic solidarity, although the question of the pre-colonial political situation remained the most decisive variable. While it is true that in the

258 NRSTG, PUB 13/12, District Commissioner of McCarthy Island to Colonial Secretary of the Gambia (number illegible), 19 Aug. 1942.

259 NRSTG, PUB 13/12, Bailes, Commissioner of Central Commission, to Senior Commissioner of Protectorate Administration, Ex-Seyfu Barra Turay (n DI.7.42/6/102.), 15 July 1950.

26o Hughes, 'Uprising', 66.

261 Kingsland, James, 'A Gambian Chieftaincy Election', Journal of Modern African Studies $15(4), 1977,651-6,65^{2-3}$. 
Gambian case, the category of being 'Wolof' has often not been the essential one, it fulfils an important function more frequently than in Senegal. In questions of land rights and rights to chieftaincies, contenders were aware of the importance of the category; they even attempted to use colonial statistics on ethnic groups in a given district whenever those calculations worked in their favour. Unlike in Senegal, the states could not have a major role in shaping local identifications, as the early British insistence in focusing on 'tribally' correct political units encouraged ethnic mobilisation. In the northern parts of Senegambia, i.e. in Senegal, such identifications had been considered as not being very useful by the colonial power. 